\title{
WestVirginiaUniversity
}

THE RESEARCH REPOSITORY @ WVU

Graduate Theses, Dissertations, and Problem Reports

2021

\section{Validation of Shoulder Strain Index}

Fabiha Islam

fi00001@mix.wvu.edu

Follow this and additional works at: https://researchrepository.wvu.edu/etd

Part of the Ergonomics Commons

\section{Recommended Citation}

Islam, Fabiha, "Validation of Shoulder Strain Index" (2021). Graduate Theses, Dissertations, and Problem Reports. 10282.

https://researchrepository.wvu.edu/etd/10282

This Thesis is protected by copyright and/or related rights. It has been brought to you by the The Research Repository @ WVU with permission from the rights-holder(s). You are free to use this Thesis in any way that is permitted by the copyright and related rights legislation that applies to your use. For other uses you must obtain permission from the rights-holder(s) directly, unless additional rights are indicated by a Creative Commons license in the record and/ or on the work itself. This Thesis has been accepted for inclusion in WVU Graduate Theses, Dissertations, and Problem Reports collection by an authorized administrator of The Research Repository @ WVU. For more information, please contact researchrepository@mail.wvu.edu. 


\title{
Validation of Shoulder Strain Index
}

\author{
Fabiha Islam
}

Thesis submitted

to the Benjamin M. Statler College of Engineering and Mineral Resources at West Virginia University

in partial fulfillment of the requirement for the degree of

\author{
Master of Science \\ in \\ Industrial Engineering
}

\author{
Ashish D. Nimbarte, Ph.D., Chair \\ Feng Yang, Ph.D. \\ Hongwei Hsiao, Ph.D.
}

Department of Industrial and Management Systems Engineering

Morgantown, West Virginia

2021

Keywords: Shoulder Biomechanics; Strain Index; Forceful Arm Exertion; SEMG

Copyright 2021 Fabiha Islam 


\section{Abstract \\ Validation of Shoulder Strain Index}

\section{Fabiha Islam}

Musculoskeletal disorders (MSDs) of shoulder are one of the most frequent and major causes of morbidity and pain among full-time workers in the USA. In 2018, shoulder disorders were the most severe type of MSDs in terms of lost workdays. Recent epidemiological studies have identified several biomechanical, organizational, and psychological factors that increase the risk of shoulder MSDs. Though multiple biomechanical studies have evaluated physical causal factors of shoulder MSDs with a goal of risk mitigation, literature lacks a standardized risk assessment tool. The main objective of this study was to validate a previously developed shoulder strain index. The strain index is based on the concept of shoulder stabilizing concavity compression mechanism. A two-fold process was used to conduct the validation: (1) Forty different forceful arm exertions characterized by two shoulder planes, two shoulder angles, two force levels and five orthogonal directions of force exertion were modelled using a full body biomechanical modeling software (AnyBody Modeling System ${ }^{\mathrm{TM}}$ ). The magnitude and direction of internal joint reaction forces acting at glenohumeral joint were used to estimate the shoulder strain index. (2) The surface electromyography data recorded from seven shoulder stabilizing muscles were analyzed to estimate the total physiological demand on the shoulder complex. Statistical analysis was performed to understand the effect of forceful arm exertions on the strain index and to quantify its relationship with the shoulder physiological demand. The strain index was significantly affected by work-related factors such as shoulder plane, shoulder angle, force exertion level and direction. The correlation coefficients of 0.7 ( $\mathrm{p}<0.001)$ was observed between total physiological demand and the strain index indicating that shoulder strain index tested in this study is a good estimator of physiological workload and can serve as an assessment tool to predict risk of shoulder MSD due to forceful manual material handling tasks. 


\section{Acknowledgements}

It is my immense pleasure to acknowledge and give my warmest thanks to all of them who have been continuously assisted me to complete my master's thesis. First of all, I would like to express my sincere gratitude to my supervisor Dr. Ashish Nimbarte who has made this work possible. His constant supervision, encouragement, and support have helped me to go through all the stages of conducting and writing this project.

I pay my deep sense of gratitude and respect to the other members of my thesis committee, Dr. Feng Yang and Dr. Hongwei Hsiao for their endless support and valuable guidance.

I would like to thank my colleagues, friends, and the staff of the Industrial and Management Systems Engineering department for directly and indirectly assisting me in several ways.

I also thank my beloved parents for being an important inspiration and supporting me in many ways. Finally, I want to express my sincere thanks to all my well-wishers. 


\section{Table of Contents}

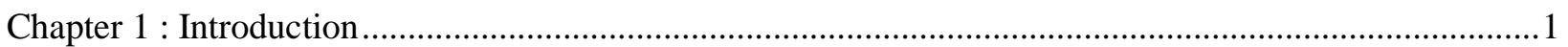

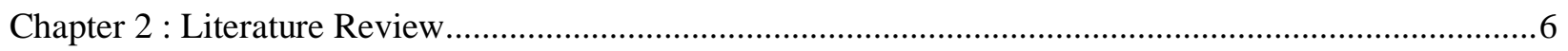

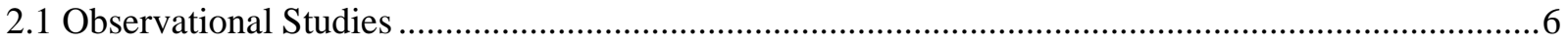

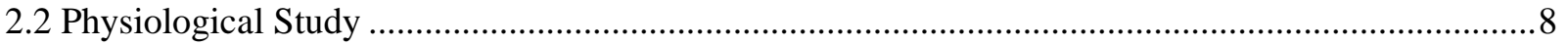

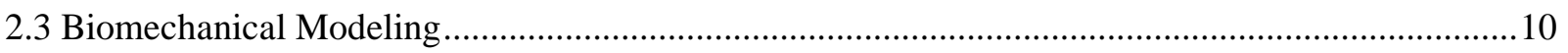

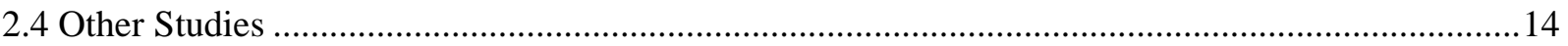

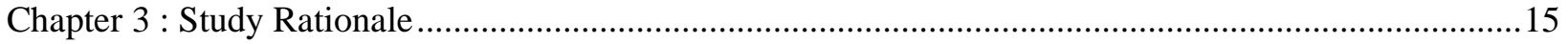

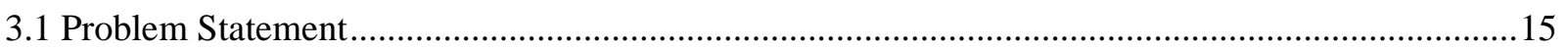

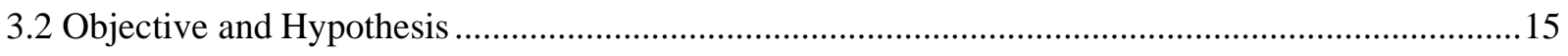

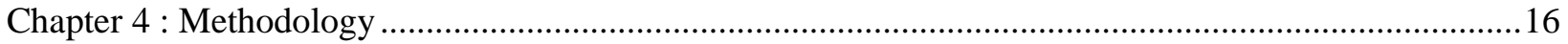

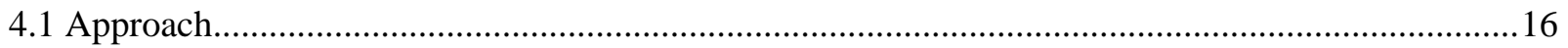

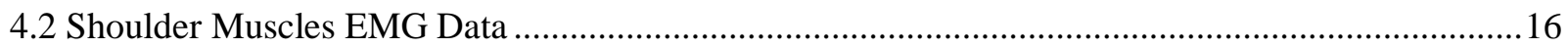

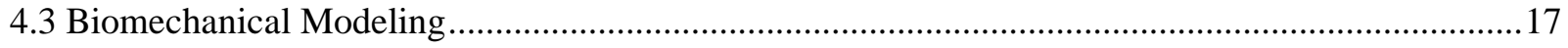

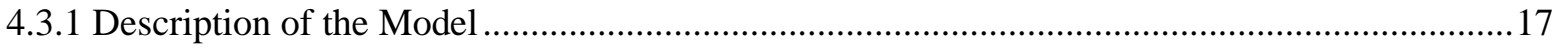

4.3.2 Model Modification Procedure ...................................................................................... 18

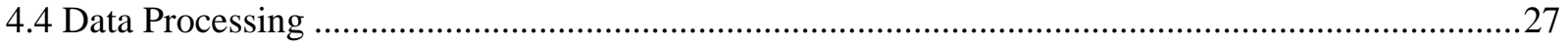

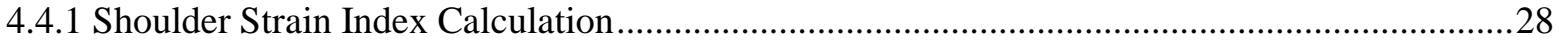

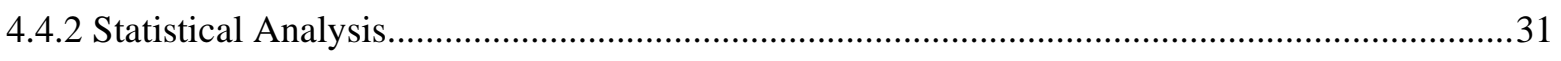

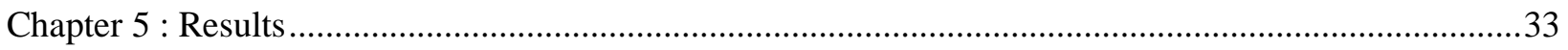

5.1 Effect of Forceful Arm Exertions on Strain Index (SI) ..................................................................

5.2 Correlation between Muscle Activation and Shoulder Strain Index ................................................41

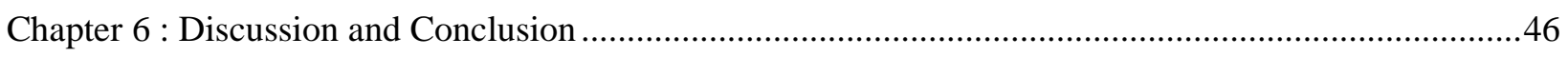

6.1 Study Limitations and Direction for Future Studies.....................................................................51

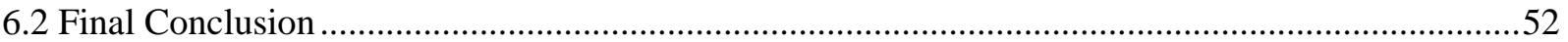

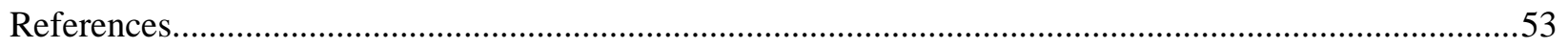

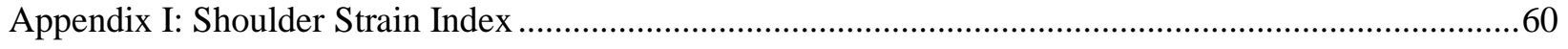

Appendix II: RMS Values of Shoulder Muscles ...............................................................................64 


\section{List of Figures}

Figure 1.1: Shoulder Bones: Clavicle, Scapula, and Humerus.

Figure 1.2: Shoulder Joints: Glenohumeral Joint, Scapulothoracic Joint, Acromioclavicular Joint, and Sternoclavicular Joint . .3

Figure 1.3: (a) Ball and Socket Joint of Glenohumeral Joint (b) Concavity Compression Mechanism .......4

Figure 4.1: Forceful arm exertions performed at various angles, planes, and force direction conditions...17

Figure 4.2: Standing model obtained from AnyBody Modeling System ${ }^{\mathrm{TM}}$...........................................18

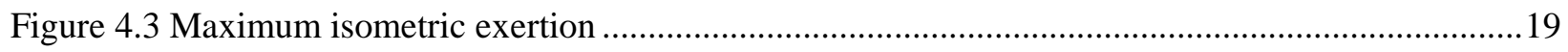

Figure 4.4 Forceful exertions in sagittal plane with $60^{\circ}$ shoulder angle .............................................21

Figure 4.6 Forceful exertions in sagittal plane with $120^{\circ}$ shoulder angle .............................................25

Figure 4.7 Forceful exertions in scapular plane with $120^{\circ}$ shoulder angle ............................................27

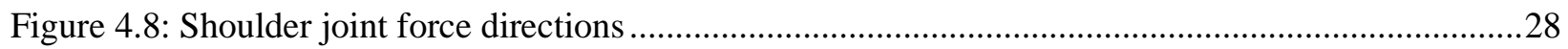

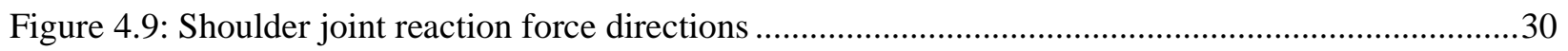

Figure 5.1: Mean and 95\% CI for all combinations of main factors .....................................................35

Figure 5.2: Mean and 95\% CI for all combinations of main factors (Continued) ....................................36

Figure 5.3 Mean and 95\% CI for all combinations of main factor levels................................................3

Figure 5.4 Mean and 95\% CI for all combinations of main factor levels (Continued) ..............................40

Figure 5.5 Mean and 95\% CI for all combinations of main factor levels (Continued) .............................41

Figure 5.6 Relationship between individual muscles and average strain index .....................................4

Figure 5.7 Relationship between average muscle activation and strain index .......................................45

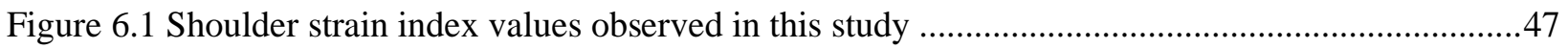




\section{List of Tables}

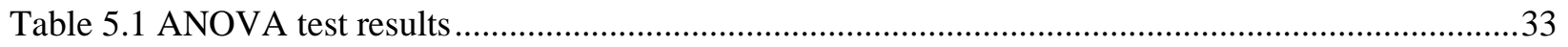

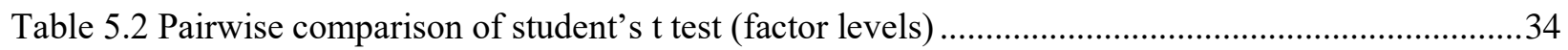

Table 5.3 Pairwise comparison of student's $t$ test (combination of factor levels)......................................36

Table 5.4 Correlation between individual muscles and average strain index...........................................42 


\section{Chapter 1: Introduction}

Musculoskeletal disorders (MSDs) are reported as the most frequent and significant workrelated injuries among full-time workers in different occupational sectors. The Bureau of Labor Statistics indicates that in 2018, MSDs accounted for 50\% of all illness cases in industries and $40 \%$ of all illness cases in occupational sectors. Particularly, shoulder disorders experienced by the workers are the most common MSDs in occupational settings. According to the Bureau of Labor Statistics (BLS), shoulder disorders were the most severe type of MSDs in terms of lost workdays in 2015, which resulted in 23 median lost workdays whereas all other MSDs resulted in 9 median lost workdays (Chowdhury et al., 2018). Moreover, shoulder MSDs bring about huge direct and medical expenses. The compensation allocation of the direct cost for work-related shoulder disorders from 1997 to 2005 was \$16,092 per claim in the state of Washington. Additionally, it has been observed that indirect costs such as reduced health, impaired task ability, decreased productivity, and low quality is ideally higher in the industrial sectors compared to other occupational and service sectors (Alasim et al., 2019).

Recent studies have found that workers of certain industries such as retail trade, manufacturing, healthcare and social assistance, transportation and warehousing, construction, agriculture, forestry, fishing and hunting suffer the most from shoulder MSDs. However, operators in other occupational and service sectors also suffer from shoulder fatigue as they are exposed to prolonged static or repetitive loads for a major part of the working day. These occupations include freight, stock and material movement, nursing and health care assistance, heavy tractor-trailer truck and delivery service driving, maintenance and repair work (Bureau of Labor Statistics, 2018). In general, the prevalence rate of MSDs is higher among male workers (37.5 per 10, 000) compared to female workers (29.7 per 10,000) (Charles et al., 2018). Suffering from shoulder discomfort and loss of function are common complications among the patients (van der Windt et al., 1995). Another primary shoulder complication is rotator cuff disorder, which is found in people who perform repetitive exertion tasks. Moreover, the anatomical conflict between the intrinsic and extrinsic factors results in partial or complete tears of the rotator cuff tendons, frozen shoulder, subacromial bursitis, joint impingement syndrome, and pain in the glenohumeral joint (Bramanet al., 2014; Cudlipet al., 2018). 
Multiple studies have identified several biomechanical, organizational, and psychological factors that increase the risk of shoulder MSDs at the workplace. Biomechanical hazards such as forceful arm exertions, awkward postures, repetitive motions of upper extremities, hand, arm, and full-body vibration, unbalanced workstations as well as insufficient recovery time are significant risk factors of subacromial diseases (Bodin et al., 2020; Chowdhury et al., 2018). Additionally, there is ample evidence that mechanical impingement and biomechanical overloading also lead to the development of shoulder disorders among industrial workers (Braman et al., 2014; Alasim et al., 2019). In addition to the biomechanical influences, epidemiological investigations have documented different organizational factors that are associated with shoulder disabilities. These exposures include but are not limited to an uncomfortable sitting posture, limited rest or breaks, and unavailability of adjustable office desks. Furthermore, several psychosocial conditions of the work environment such as high job demands but lower levels of control, poor support from supervisors and colleagues disrupt the muscle activation, leads to a higher level of muscle stress resulting in muscle fatigue (Jiskani et al., 2020; Mehrdad et al., 2010; Roquelaure, 2018)

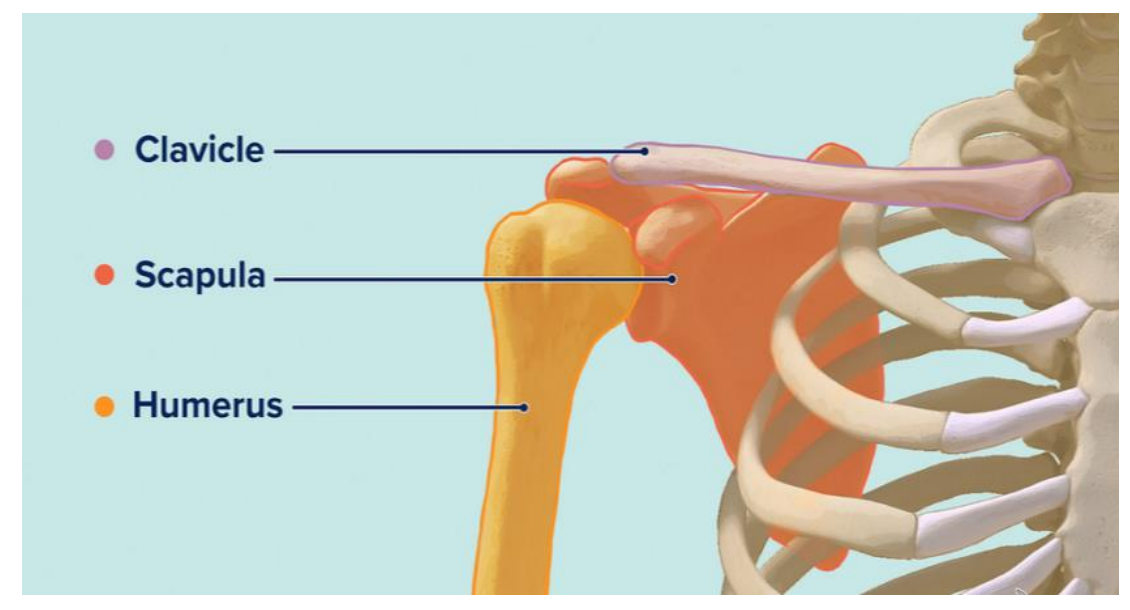

Figure 1.1: Shoulder bones: clavicle, scapula, and humerus ${ }^{i}$

The human shoulder is a complex combination of numerous muscles, ligaments, and tendons that enable flexible movements of the shoulder across several degrees of freedom and multiple planes. The shoulder complex is comprised of three bones: clavicle, scapula, and humerus (Figure 1.1). The clavicle, also known as the collarbone, extends from the shoulder blade to the 
sternum and meets the acromion in the acromioclavicular joint. The scapula is a flat triangularshaped bone that is located at the poster lateral side of the thoracic cage and links the humerus with the collar bone. The humerus is a long bone that connects the scapula with the radius and ulna. In order to translate an extensive range of motion, these three bones meet at an angle of $90^{\circ}$ and create four basic shoulder joints.

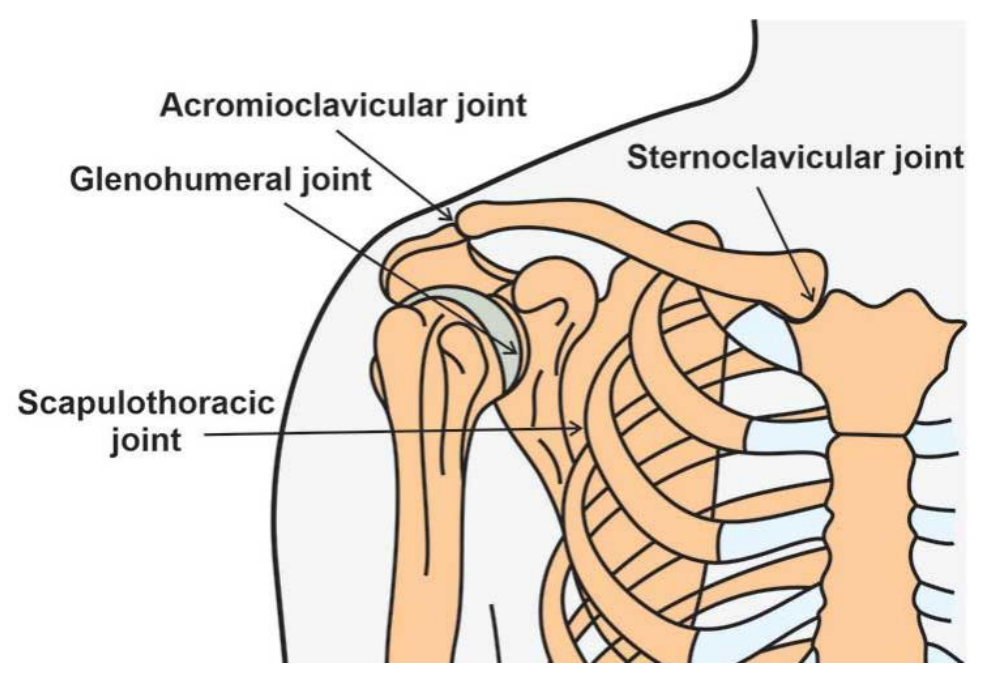

Figure 1.2: Shoulder joints: glenohumeral joint, scapulothoracic joint, acromioclavicular joint, and sternoclavicular joint ${ }^{\mathrm{ii}}$

The fundamental shoulder joints are the glenohumeral joint, scapulothoracic joint, acromioclavicular joint, and sternoclavicular joint (Nicolozakes, 2021) (Figure 1.2). The glenohumeral joint is the main joint of the shoulder which is a ball and socket type joint made by the humerus head and scapula (Figure 1.3a). As the humerus head is larger than the glenoid cavity, it fits slightly free in its movement, allowing extension, flexion, abduction, and rotation at the cost of underlying instability. The shoulder joint instability causes the humeral head to translate away from the glenohumeral cavity and compresses the soft tissues which result in subacromial impingement (Mulla et al., 2020). In order to support the humeral movement and make the shoulder stable, the joint is surrounded by a group of muscles and tendons, known as the rotator cuff. Supraspinatus, infraspinatus, teres minor, and subscapular are four muscles of the rotator cuff originating from the scapula. Anterior deltoid, lateral deltoid, and posterior deltoid are three muscles that facilitate glenohumeral elevation and rotation. When an external force is applied to 
the shoulder, these muscles produce a compressive force in order to counteract that external force. For stabilizing the shoulder joint, this compressive force must be larger than the individual translational forces. The mechanism through which this coordinated action is maintained is called the concavity compression mechanism (Lazarus et al., 1996; Lippitt et al., 1993) (Figure 1.3b).

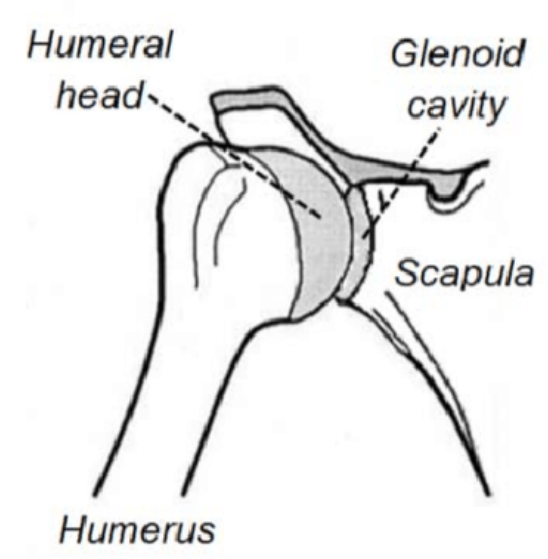

(a)

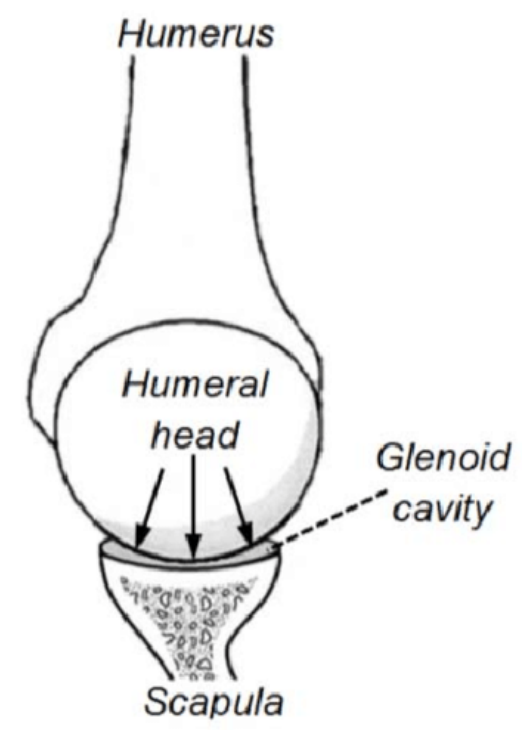

(b)

Figure 1.3: (a) Ball and socket joint of glenohumeral joint (b) concavity compression Mechanism ${ }^{\text {iii }}$

Numerous studies have proposed several clinical and research approaches to detect the sources of shoulder disorder, quantify the amount of discomfort and reduce the risk of exposure. These include the use of self-reported checklists, Shoulder Pain and Instability Index, Quick DASH, ultrasound imaging, and multiple readily available devices (Curtis et al., 1995; da Silva et al., 2018; Minoughan et al., 2018; Sudarshan et al., 2019; O’Sullivan et al., 2012). In a recent study, Chowdhury et al., (2018) proposed the use of the shoulder strain index which is developed based on the functionality of the concavity compression process. This is relatively new tool and sufficient data is not available regarding its reliability and validity. In order to prevent the work related MSDs (WMSDs) of shoulder, it is critically important that accurate and fully validated workplace assessment tools are available to the employers. Toward this goal, in this study, the 
strain index developed by Chowdhury et al., (2016) will be further examined and evaluated to test its efficacy in predicting risk of shoulder WMSDs during work-related forceful arm exertions. 


\section{Chapter 2: Literature Review}

Previous studies investigating the relationship between musculoskeletal strain and external force, the direction of arm exertion, and posture have utilized several different methodologies. These methodologies can be broadly categorized into three main groups: observational studies, physiological studies, and biomechanical modeling. Each group has its own methodology with each having its own set of advantages and drawbacks. Below, a brief review of these studies is presented.

\subsection{Observational Studies}

The goal of an observational study is to analyze the consequence of a treatment that is not randomized and affected by any designed procedure. In general, during the experiments, either the subjects select their own way of conducting the experiment, or their process, as well as output, is affected by the environment (Rosenbaum 2005). Several studies have attempted to develop observational methods to measure the intensity, frequency, and duration of exposure in a systematic and comprehensive manner (Andreas \& Johanssons, 2018). In recent years, Health and Safety executives have suggested a number of survey techniques, self-reported questionaries, video recordings, and other observational aids to acknowledge the etiology, chronicity, and severity of shoulder disorder (Linaker \& Walker-Bone, 2015). The most commonly used tools are Rapid Upper Body Assessment tool (RULA), Rapid Entire Body Assessment (REBA), Quick Exposure Check, The American Conference of Governmental Industrial Hygienists Threshold Limit Value (ACGIH TLV), Video Exposure Monitoring (VEM), Nordic Musculoskeletal Questionnaire (NMQ) (Beese et al., 2021; Chu et al., 2021; Hignett \& McAtamney, 2000; Nadri et al., 2013; Thomas et al., 2021). One important aspect of observational studies is that they provide insightful information that is often concealed in randomized experiments. The advantages of observational studies are that they are simple and consider a wide range of socio and psychological factors (Suissa \& Garbe, 2017).

Questionaries and checklists allow researchers to understand the personal factors, organizational orientation, psychological and biomechanical stresses among a larger group of individuals. In one such study conducted by Thomas et al., (2021), the investigators compared the 
general risk assessment tool used by the local health and safety executives with Body Mapping and MSD ill-health absence rate during domestic waste collection. The participants reported that they experienced the highest fatigue in moving 1001 sacks containing garden waste and recycling boxes while the lowest level of pain was associated with serving the 2401 wheeled bins. In order to reduce the MSDs among the workers, they suggested redesigning the waste collection process and proposed to use a body mapping strategy for the risk assessment (Thomas et al., 2021). Chu et al., (2021) used Nordic Musculoskeletal Checklist incorporated with a multivariable logistic regression model to find out the personal as well as work-related risk factors associated with shoulder disorder. They hired 931 electronics workers to gather necessary information about movement frequency, posture, load, and time of exposure. One of their major findings was that multiple components including age, repetitive exertions, working posture, and external loads had the most significant influence on developing shoulder symptoms among male workers. In contrast, shoulder fatigue among female workers was influenced mostly by the posture at the workplace (Chu et al., 2021). Kee (2021) compared Ovako Working Posture Analysis System (OWAS) against Rapid Upper Limb Assessment (RULA) and Rapid Entire Body Assessment (REBA) using 209 medical samples associated with MSDs. The author found that RULA and REBA had better action levels than OWAS and based on the grand score, RULA serves the best for estimating the postural load (Kee, 2021).

Apart from the observational surveys, several video monitoring assessment techniques have been employed for investigating the exposure and the working environment in a more objective manner. These video-based assessment tools combined with motion tracking devices and other sensors can provide a more accurate and documented picture of the category of workload, exposure angles, duration, and frequency at each posture. Moreover, they provide more critical and corrective measures compared to traditional physical load computation techniques (Heberger et al., 2012; Hernandez et al., 2019; McKinnon et al., 2019; Pehkonen et al., 2009). In a current study, Polat et al., (2016) combined video recordings with Ovako Working Posture Analysis System (OWAS) to analyze the physical workload and risk factors during loading and unloading the machinery in a medium-sized wood processing factory. From this combined assessment the authors found that five machines among twelve had the most hazardous effect on the musculoskeletal system of the workers and suggested ergonomic improvements of the operational settings (Polat et al., 2016). Forsman et al., (2006) proposed an integrated method of VIDAR and 
Quick Exposure Checklist, where operators were asked to identify the physically demanding situations, the amount and zone of fatigue, and the external load weight from pre-recorded video clips. Once the hazardous situations were identified by the operators, they were printed out and the checklist was implemented to assess the workload in the back, shoulder, wrist, and neck region (Forsman et al., 2006). Syuaib (2015) applied video recording system to analyze the work motion of 141 harvesting workers near the shoulder and arm area The results showed that the current working posture are not safe for the harvesters and they require immediate ergonomic interventions (Syuaib, 2015).

Observational experiments are simple and economical tools that have served as a great method of measuring exposure in the work environment and suggesting improvements considering musculoskeletal disorders (Chu et al., 2021). However, several occupational studies have addressed some major drawbacks of the application of these tools. Sometimes, the self-assessment questionaries which are used to gather the participant's physiological information are not directed by specialists. Additionally, because of their immense subjectivity and substantial chances of missing important information, these observations may generate inappropriate results (Beese et al., 2021). Another major fact is that although these surveys and checklists are very effective for running up among larger groups, they are often inconsistent with the recommended guidelines (Smythe et al., 2021). In addition, it is tedious for human observers to process a huge amount of subjective information and use it for a holistic judgment and pain management (Pinto et al., 2011; Posada-Quintero et al., 2021).

\subsection{Physiological Study}

Physiological studies can be defined as a controlled and observational study of integrated functional changes of the human body (Lim et al., 2013). Electromyography (EMG), Electrocardiograms (EKGs), Electroencephalogram (EEG), Heart Rate (HR), Event-Related Brain Potentials (ERPs), and Blood Pressure (BP) are some of the diverse measuring tools available that facilities the researcher to better understand the body's physiology. The purposes of recent psychological studies while workload assessment is to evaluate the physiological loads, effects of certain tasks on the strength of muscle, and examine if the load falls within the allowable limit or 
not. Physiological studies have been widely used because of their certain advantages over other traditional workload evaluation processes. The advantages of these studies are they provide more specific and unambiguous information indicating the problematic design and they are vastly reliable tools for dynamic risk assessment (Kramer 2020; Tran et al., 2007).

The combination of neurophysiological patterns such as EEG frequency and EMG signals can be used as good indicators of musculoskeletal pain in the shoulder complex for repetitive exertions. Segning et al., (2021) used EEG signals to estimate the cortical activity by analyzing the beta EEG frequency band ( $\beta$.EEG) of the task-related power increase/decrease. For this experiment, they recruited ten healthy male and two female participants for performing tasks with high and low risk of muscle pain development for 30 minutes. EEG signals were collected by placing EMG electrodes on the anterior and deltoid muscle, the Power Spectral Density (PSD) and Coefficient of Variation ( $\mathrm{CoV}$ ) were used to quantify the pain scores. One of their major findings was that a $\beta>=50 \%$ and $\mathrm{CoV}<=18 \%$ provides a reliable index for assessing shoulder pain (Segning et al., 2021). In another study conducted by Grauhan et al., (2021), a convolutional neural network was trained using 2700 shoulder radiographs, and the model was used as an assistive device for identifying the most common causes of shoulder pain. The model found the factors that extensively explained the fatigue such as the proximal humeral fractures, joint dislocation, periarticular calcification, osteoarthritis, osteosynthesis, and joint endoprosthesis. Posada-Quintero et al., (2021) applied machine learning approach to electrodermal activity (EDA) in order to estimate the pain agitation in twenty-three subjects during the exposure to thermal grills. The regression model achieved the $R^{2}$ values of 0.357 and 0.47 for stimulation intensity and pain sensation respectively. The authors concluded that the EDA are closely correlated to stimuli's intensity and pain sensation reported by the subject (Quintero et al., 2021).

The surface EMG signals are one of the quickest and noninvasive ways of exhibiting human motions executions. Their use has been recognized as an important control signal as it can produce very reliable and promising results and are being widely used by many researchers in recent history (Liu et al., 2019). Goubault et al., (2021) conducted an experiment where EMG data from ten shoulder muscles of thirty healthy men were collected during the loading and unloading of the pallet in a grocery warehouse for 45 minutes. After processing the data, it was found that among all the EMG indicators, spectral entropy, median frequency, and mobility are the best to assess the modified Rate of Perceived Exertion (RPE). Additionally, they suggested that the 
combination of these three indicators can improve the assessment result of the myoelectric manifestation of fatigue. Nimbarte et al., (2010) collected EMG signals from sternocleidomastoid and upper trapezius muscles during lifting tasks at neutral, maximally flexed, and maximally extended neck postures to identify the risk factors among construction workers. The EMG signals indicated that the upper trapezius muscle and the sternocleidomastoid muscle were most active at the flexed neck and extended neck posture respectively. Their result suggested that these tasks contribute significantly to neck disorders among construction workers. Wang et al., (2000) evaluated jaw muscle pain by collecting EMG signals from the masseter and anterior temporalis muscles of twelve participants. Jiang et al., (2020) employed surface EMG for controlling the motion of rehabilitative robotic assistive devices and testing the validity machine learning algorithm used to control the shoulder motion pattern.

The physiological tools are very informative while studying the activation patterns of different muscles, which in turn can help to identify the risk factors and estimating the musculoskeletal loading. However, they have their own set of constraints and limitations. Though the physiological signals represent the neuromuscular components of fatigue; they vary from subject to subject and cannot be used alone for an integrated fatigue assessment (Goubault et al., 2021). To produce more accurate results, they should be validated using other assessment tools. Additionally, the placement of the markers is very challenging as the muscle fibers are surrounded by layers of muscles, fats, and tissues. These biological structures can affect the precise placement of the markers, modify the impedance of the electrodes thus leave a remarkable effect on the recorded signals (Artemiadis, 2012).

\subsection{Biomechanical Modeling}

Biomechanics can be defined as the study of the movement mechanism of living things by analyzing the methods of mechanics, motion, and forces (Hatze, 1974). It is the detailed study of biological structures which help physical and occupational therapists to understand the functions of the musculoskeletal system and joints. Forces acting on living things can produce motion, act as a stimulus for growth and development, or overload tissues, which in turn causes serious neurological injuries. Biomechanics provides conceptual and mathematical tools and models that 
help health and safety professionals to evaluate the forces, motions, stress, and strain working on the subjects during biomechanical loading ( $\mathrm{Lu} \&$ Chang, 2012). Hence, miscellaneous biomechanical models have been developed and employed to prevent occupational injuries and provide a safer working environment by illustrating the capacity of the musculoskeletal system. One important aspect of these models is that they consider the force transfer mechanisms and amount of internal joint stability while evaluating the external and internal loadings. The main advantages of biomechanical models are that they can simulate motions that need not to be physically performed in the laboratory or industrial settings and provide a better computational structure of the intricated interaction among the soft tissues (Högfors et al., 1991; Zheng et al., 2020).

There exist several open and closed-loop biomechanical shoulder models which are used by experts where, rigid links are connected through joints that allow movements in threedimensional planes (Lenarčič \& Klopčar,2006; Tondu, 2005; Yang et al., 2003). These models consider the coupling of the shoulder joints during abduction-adduction, flexion-extension, and rotation and apply various shoulder girdle mechanisms, techniques, and coordination systems to analyze the shoulder complex. Though these models are good estimators of forces acting on the segments, they do not consider the muscles and sometimes they result in mathematical singularities (Yang et al., 2010). The actual position and movement of bones vary significantly from the conceptual models (Högfors et al., 1991) and these models do not consider the effects of muscle fibers. On the other hand, musculoskeletal models provide more accurate results by considering the internal structural loadings and muscle activation and thus can be used for accurately analyzing the motion.

The conceptualization of morphological computation has inspired the development of musculoskeletal models which are able to simulate a wide range of human movements at a convenient price. The applications of these models have served as a key component for imitating infrequent and unusual performances that are very difficult to regulate in practical situations. One such example is found in the study conducted by Do et al., (2019) where, they used OpenSim to simulate dislocated acromioclavicular joints and evaluate the movement of upper limbs. Using data of ten men they verified that the model can be used for abnormal movement and motion analysis. Mansouri \& Reinbolt (2012) proposed a new interface by integrating OpenSim and 
Simulink to offer their combined strengths, numerical and dynamic simulations and to use by neuroscientists, physiologists, biomechanists, and physical therapists. Odle et al., (2011) used a shoulder model in OpenSim to understand the relationship between impulsion and shoulder injury among manual wheelchair users. One of their findings was that the shoulder model can be used as a reliable and accurate means for investigating dynamic movements. Panariello et al., (2019) used OpenSim for replicating overhead leveraging and drilling tasks performed at industrial settings. They captured the kinematic data using optical motion capture system, evaluated the joint angles through the kinematic analysis and concluded that OpenSim can be used to evaluate the overhead tasks appropriately.

Another commercially available modeling system is 3DSSPP, which allows users to predict the static strength data for manual material handling tasks through the three-dimensional human model form. This software allows its users to identify and quantify the risk factors quickly without having to do any manual calculations. Feyen et al. (2000) used the combined interface of AutoCAD and 3DSSPP to evaluate the design of a workplace. In this study, the authors evaluated biomechanical risk factors of a manual material handling task and computed the reach distance, clearance, and visual requirements of a workplace. The outcome was compared with a previously established result and both indicated that the biomechanical stress experienced by the workers exceed the NIOSH limit. Thus, the authors proposed that this combination is a valid tool for assessing workplace designs. Merryweather et al. (2009) used 3DSSPP to revise and reduce the assumption error of a basic hand-calculation back compressive force (HCBCF) estimation model. For this purpose, the back compressive force of L5/S1 intervertebral disk, torso flexion angle, and upper body mass center location was calculated in 3DSSPP with 6000 observational data for male and female subjects. The result showed that though the HCBCF model exaggerated the back compressive force for L5/S1 disk while comparing with 3DSSPP, the predictive capability and accuracy of the model were relatively high after revision. However, the HCBCF models do not allow asymmetric movement during material handling and do not consider the body mass distribution. Thus, it was concluded that the HCBCF model is a simple alternative to a computerbased model and it can be used to sort out the data for analysis in a more complex model. Matebu et al. (2014) calculated the forces exerted by the workers and created the 3D posture using the anthropometry data of both male and female workers who had been working in the industry for over 20 years. The researchers compared the resulted postures used by the workers with NIOSH 
standard and found that the current posture is unacceptable. Therefore, they proposed and applied some modifications to the workplace, analyzed the data in 3DSSPP and the result exhibited that the posture has been improved and the force required to pull or push has reduced to $194.23 \mathrm{~N}$ from 931.77N . Asadi et al. (2015) conducted a study on 120 workers from 7 industrial settings in the city of Shiraz in order to determine the prevalence of musculoskeletal disorders and forces exerted on the lower back of the workers during manual load lifting. The reaction forces were determined using 3DSSPP and were found that in $17.5 \%$ of the compressive forces, and $10.8 \%$ cases of shearing forces exerted on the L5-S1 disc exceeded the permissible levels.

Virtual prototyping affiliated with multibody dynamics, mathematics, artificial intelligence, physiology, and software engineering is extensively being used for evaluating the biomechanical loading and calculating the strain placed on the musculoskeletal systems (Rasmussen et al., 2003). AnyBody Technology is such a software that is capable of analyzing the biomechanics of the human body as well as rigid structures using forward and inverse kinematics (Damsgaard et al., 2006). Several previous studies have confirmed the use of AnyBody for investigated biomechanical loading. For instance, Bassani et al., (2017) focused on validating the usability of the AnyBody full-body musculoskeletal model while calculating the loads placed on the lumbar spine at the L4L5 level. For this purpose, 12 specific exertion tasks were replicated into AnyBody by importing the motion capture data and the intradiscal pressure around the L4L5 region was calculated in vivo. While comparing the lumbar spine loads generated by AnyBody with the pressure in vivo, the authors observed a positive agreement between them, thus exhibiting the suitability of the AnyBody modeling system. Additionally, Ji et al (2016) used surface EMG signals to check the rationality of AnyBody while computing the stress of upper extremity during bench press tasks. The statistics of EMG data collected from bow deltoids, right bicep brachii, right triceps brachii, right flexor carpi ulnaris, and trunk pectoralis muscle highly validated the results obtained from AnyBody.

Recently, the use of several biomechanical software has gained popularity for successfully modeling and simulating diverse musculoskeletal movements including sitting, walking, cycling, running, and forceful exertions (Hamner et al., 2010). Though this software represents very advanced and dynamic methods for solving biomechanical problems, some limitations are needed to be noted. Sometimes, robust design and control components are unavailable in them, which 
complicates the accurate representation of muscle (Mansouri \& Reinbolt, 2012). Furthermore, some of these models have been build based on a time zero case scenario, as a result, the effect of muscles healing from fatigue and relaxation of tissues over time is not considered. Consequently, small changes in tissue tractions over time may affect the results (Seth et al., 2016).

\subsection{Other Studies}

In addition to the studies mentioned above, other studies have investigated several other ways of identifying the major causes of shoulder disorders. A study by Alavi et al., (2016) comprising 1488 Iranian office workers identified uncomfortable sitting posture, limited rest breaks, and unavailability of adjustable office desks as the predictors of shoulder MSDs. Antony, et al., (2010) conducted research on 16 participants who performed isometric and dynamic shoulder exertions in flexion, mid-abduction and abduction positions at the angles of $30^{\circ}, 60^{\circ}, 90^{\circ}$ and $120^{\circ}$ with no load, $0.5 \mathrm{~kg}$ load, and $30 \%$ grip condition. As gripping forces have consequential effects on muscle fiber activation and internal joint loadings, they considered that hand gripping might play a significant aspect in shoulder damage. It was observed that when the shoulder was at an angle of greater than $90^{\circ}$, the contracted muscle and moment arm diminished the moment generating potential which requires greater muscle activity. Palmerud et al., (2000) examined intramuscular pressures of the infraspinatus and supraspinatus with inflated flexion and abduction and found that blood flow rate above $40 \mathrm{mmHg}$ has vulnerable effects on muscle which might result in muscle injury. 


\section{Chapter 3: Study Rationale}

\subsection{Problem Statement}

In the United States, MSDs are the most common category of occupational hazard, and causing a large amount of cost in terms of lost workdays and other direct and indirect costs. Among all the work-related injuries, upper body injuries especially shoulder disorders are the third most common complaint that requires musculoskeletal-related primary care consultation. Therefore, it is very important to have shoulder risk assessment tools. Although there are several ergonomics workplace assessment tools available, only one tool - shoulder strain index by Chowdhury et al. (2016) - is a dedicated shoulder assessment tool. This is a relatively new tool and sufficient data is not available regarding its reliability and validity. In order to prevent the WMSDs of shoulder, it is critically important that accurate and fully validated workplace assessment tools are available to the employers. Toward this goal, in this study, the strain index developed by Chowdhury et al. (2016) were further examined and evaluated to test its efficacy in predicting risk of shoulder WMSDs during work-related forceful arm exertions.

\subsection{Objective and Hypothesis}

In this study, physiological muscle activity data were used to validate the biomechanical model-based strain index. The muscle activity data from a previous study were used. The data were collected from seven shoulder muscles during forceful arm exertion performed at various postures involving different direction of force exertion, anatomical planes, and exertion heights. The postures were simulated in AnyBody Modeling System to compute the reactions forces at the glenohumeral joint. The reaction force data were used to estimate the strain index. The muscle activity data were compared with the strain index data using correlation analysis. It was hypothesized that the strain index data would be highly correlated with the physiological data. 


\section{Chapter 4: Methodology}

\subsection{Approach}

A total of forty forceful arm exertions were simulated in AnyBody Technology biomechanical modelling software. The exertions were performed in five orthogonal directions, at two shoulder planes, and at two shoulder angles using two different external force levels. After successfully loading and running the model, glenohumeral joint reaction forces in medial-lateral, inferior-superior, and anterior-posterior directions were obtained. For each exertion, the strain index, which indicates the strain experienced by the shoulder, was calculated based on a previously developed model (Chowdhury et al., 2018). The real physiological strain experienced by the shoulder muscle during the exertions was computed using the electromyography (EMG) data. The EMG data were processed to estimate the root mean square values for each exertion.

\subsection{Shoulder Muscles EMG Data}

The shoulder muscle EMG data were obtained from a recently completed study in the Industrial Ergonomics lab in WVU. The data were recorded from a sample total of 12 right-hand dominant participants, of which 4 were female participants and the remaining 8 were male participants. The average height, weight, and age of the participants were $169.33 \pm 9.28 \mathrm{~cm}, 69.92$ $\pm 13.94 \mathrm{~kg}$, and $28.5 \pm 3.71$ years, respectively. Each participant performed a total of 60 forceful arm exertions ( 2 shoulder joint angles $\times 2$ shoulder planes $\times 3$ force levels $\times 5$ force direction) (Figure 4.1). Two shoulder joint angles used were: $60^{\circ}$ and $120^{\circ}$. Two shoulder planes used were: sagittal plane and scapular plane. Three force levels used were: $0 \mathrm{lb}$., $2.5 \mathrm{lb}$., and $5 \mathrm{lb}$. Five force levels used were: pull back (PB), pull down (PD), pull left (PL), pull right (PR), and pull up (PU). Each task was performed for 10 seconds, and a 1-minute resting time was provided between the tasks. 


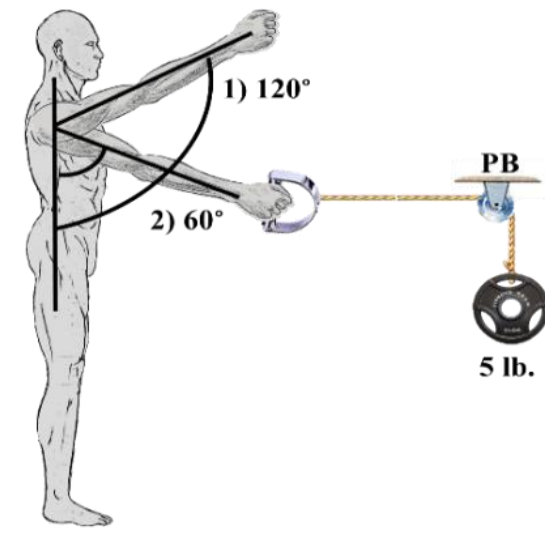

(A) Shoulder Joint Angle

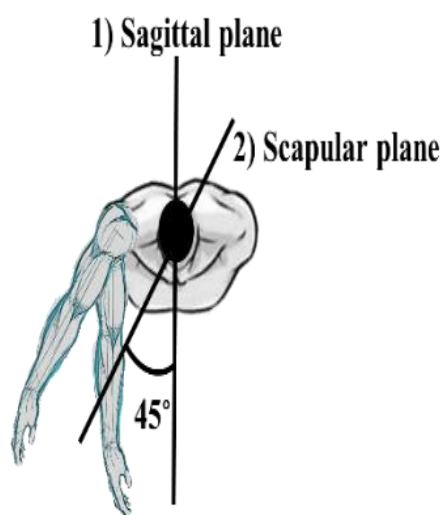

(B) Shoulder Plane

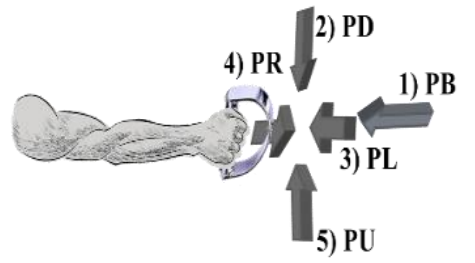

(C) Force Direction

Figure 4.1: Forceful arm exertions performed at various angles, planes, and force direction conditions

The EMG data were recorded from the shoulder muscles accessible by SEMG: supraspinatus, infraspinatus, deltoid, biceps, and triceps (long head). SEMG data for the deltoid muscle were recorded from three separate locations (middle, anterior and posterior), as these compartments of the deltoid muscle are sensitive to the direction of force exertion. Bipolar, $\mathrm{Ag} / \mathrm{AgCl}$, pre-gelled surface electrodes (Noraxon Inc., AZ, USA), with a $1 \mathrm{~cm}$ diameter and an inter-electrode distance of $2 \mathrm{~cm}$, were used for data collection. The electrodes were attached to pre-amplified lead wires with a band-pass of 10-1000 Hz (gain of 500), CMRR >100 dB, and input impedance $>100 \mathrm{M} \Omega$. A wireless EMG system (Telemyo $2400 \mathrm{~T} \mathrm{G2,} \mathrm{Noraxon} \mathrm{Inc.,} \mathrm{AZ,} \mathrm{USA)}$ was used for SEMG data collection at a sampling rate of $1500 \mathrm{~Hz}$. The root mean square values of the EMG data of the seven shoulder muscles were calculated and the average values of 12 participants were determined for each muscle.

\subsection{Biomechanical Modeling}

\subsubsection{Description of the Model}

The reaction forces for the glenohumeral joint were estimated by using a standing model from the repository of AnyBody Modeling SystemM (version 5.0, AnyBody Technology, Aalborg, Denmark) (Figure 4.2). The shoulder complex of the model consists of 118 muscle fascicles on 
each side of the body (left and right), bones, joints, and muscle-tendon units based on real physiological properties of human body. It defines the three main shoulder joints: the glenohumeral joint, the acromioclavicular joint, and the sternoclavicular joint. These joints could be driven by experimentally obtained kinematic and kinetic data. Muscle and joint forces were computed by inverse dynamics analysis and polynomial muscle recruitment pattern were employed for muscle force analysis. The standing model was modified according to the weight and height of individual participant and subsequently the model was ran using the working postures described in the previous section.

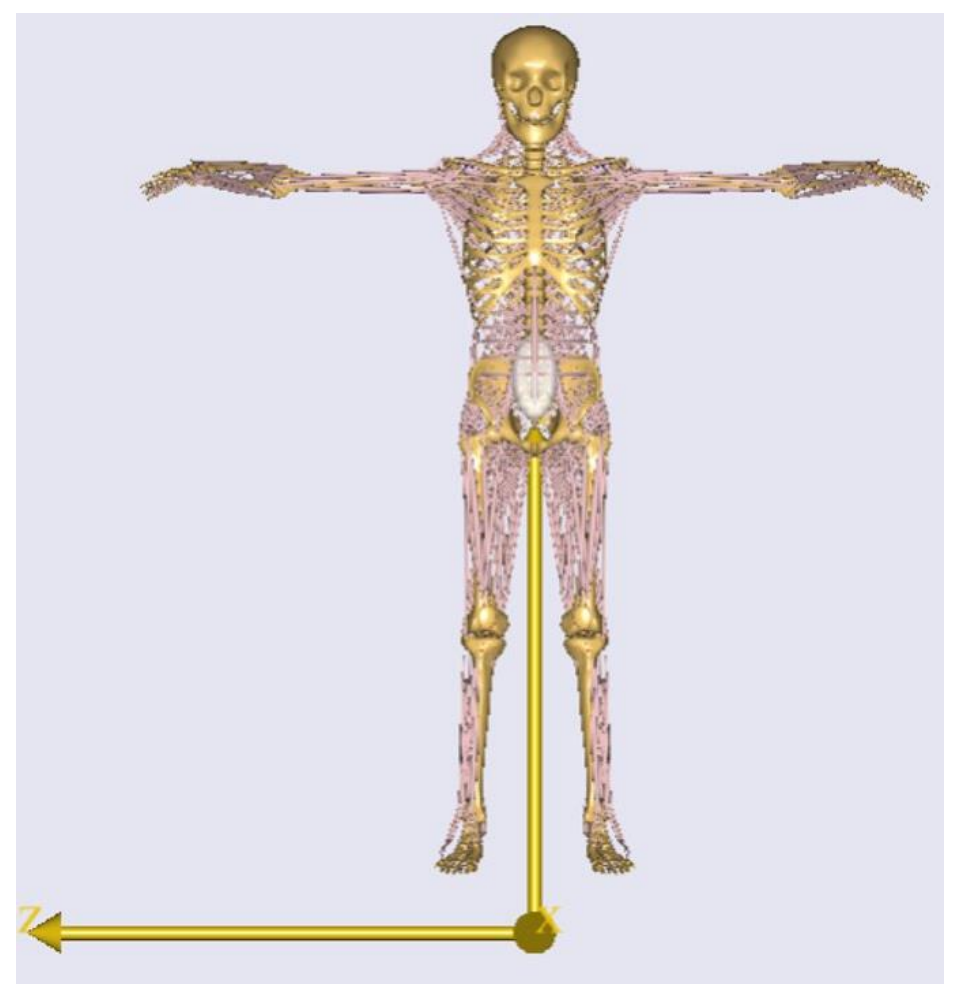

Figure 4.2: Standing model obtained from AnyBody Modeling System ${ }^{\text {TM }}$

\subsubsection{Model Modification Procedure}

The standing model was modified according to the anthropometric data and posture of individual participants. The file AnyManUniform.any within the model was used to make the 
appropriate participant-specific changes such as the standing height, body mass and gender. This feature of AnyBody allows the users to develop participant specific biomechanical models.

In order to complete the normalization process in the strain index computation process, the maximum isometric exertion was modelled and ran for 10 seconds for each participant. A task shown in Figure 4.3 was used to model the maximum isometric exertion. The task consisted of pulling up an external load of $5 \mathrm{lb}$ with shoulder joint flexed at $90^{\circ}$, forearm pronated at $45^{\circ}$, no shoulder abduction and no elbow flexion (Figure 4.3).
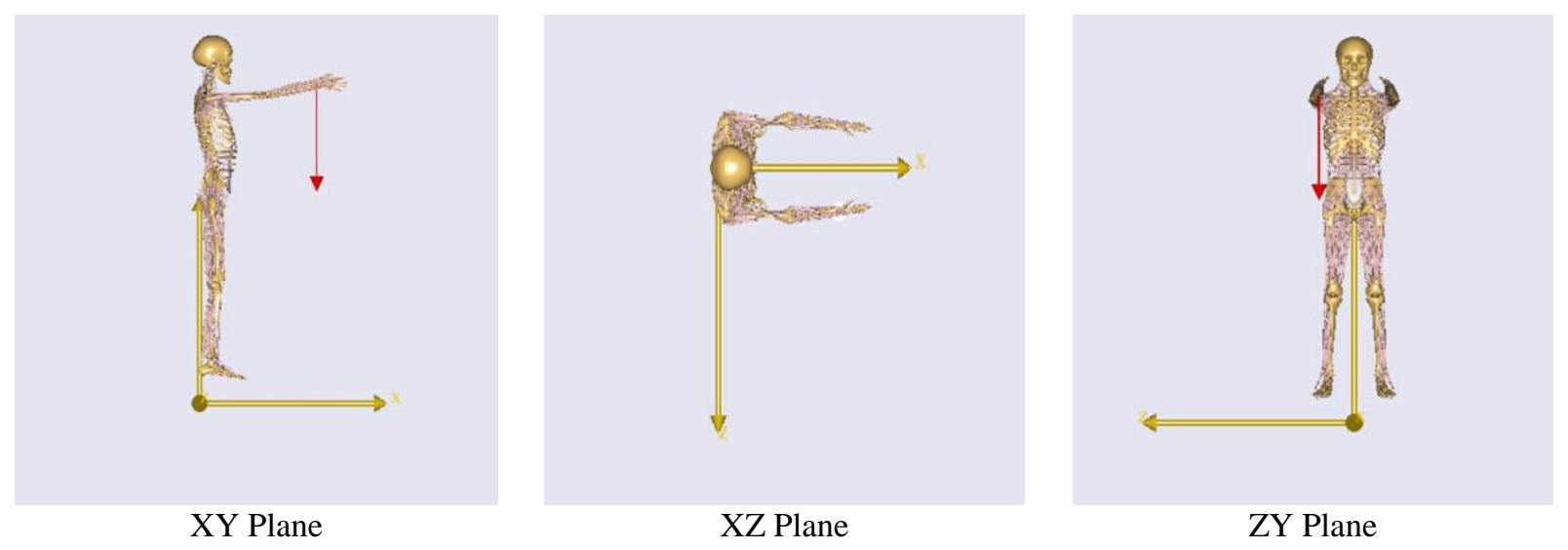

Figure 4.3 Maximum isometric exertion

Forty forceful arm exertions were simulated in AnyBody software for each participant. In the main file, the duration of each exertion was selected to be 10 seconds. The postures were obtained by modifying the Posture folder which is available in the Mannequin folder. The magnitudes of external forces were calculated in Newtons and were adjusted in the Load folder. For $2.5 \mathrm{lb}$ and $5 \mathrm{lb}$ external force, the selected values were $11.121 \mathrm{~N}$ and $22.242 \mathrm{~N}$. The five orthogonal directions of exertions were obtained by taking the positive and negative values of the external forces. For example, the positive magnitudes of the external loads in $\mathrm{x}, \mathrm{y}$ and $\mathrm{z}$ directions resulted in pulling back, pushing down and pulling left tasks respectively, while the negative magnitudes of the external loads in $\mathrm{y}$ and $\mathrm{z}$ direction resulted in pulling up and pulling right tasks. Figure 4.4, 4.5, 4.6 and 4.7 represents these postures in XY plane, XZ plane, and ZY plane. 
The first ten postures were modelled by adjusting the glenohumeral flexion at $90^{\circ}$ (Sagittal plane) and glenohumeral abduction at $60^{\circ}$ (Figure 4.4). Two external force levels $(11.121 \mathrm{~N}$ and $22.242 \mathrm{~N}$ ) were used (applied to the right hand of the model). In figure 4.4, (a) represents the exertion in backward direction, (b) represents the exertions in downward direction, (c) represents the exertions in left direction, (d) represents in right direction and (e) represents the exertions in upward directions.

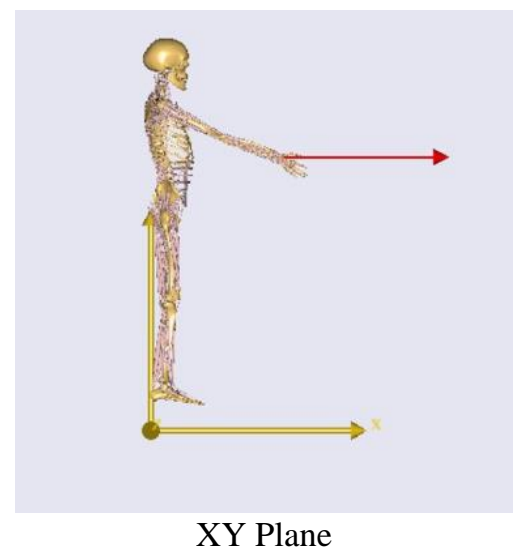

XY Plane
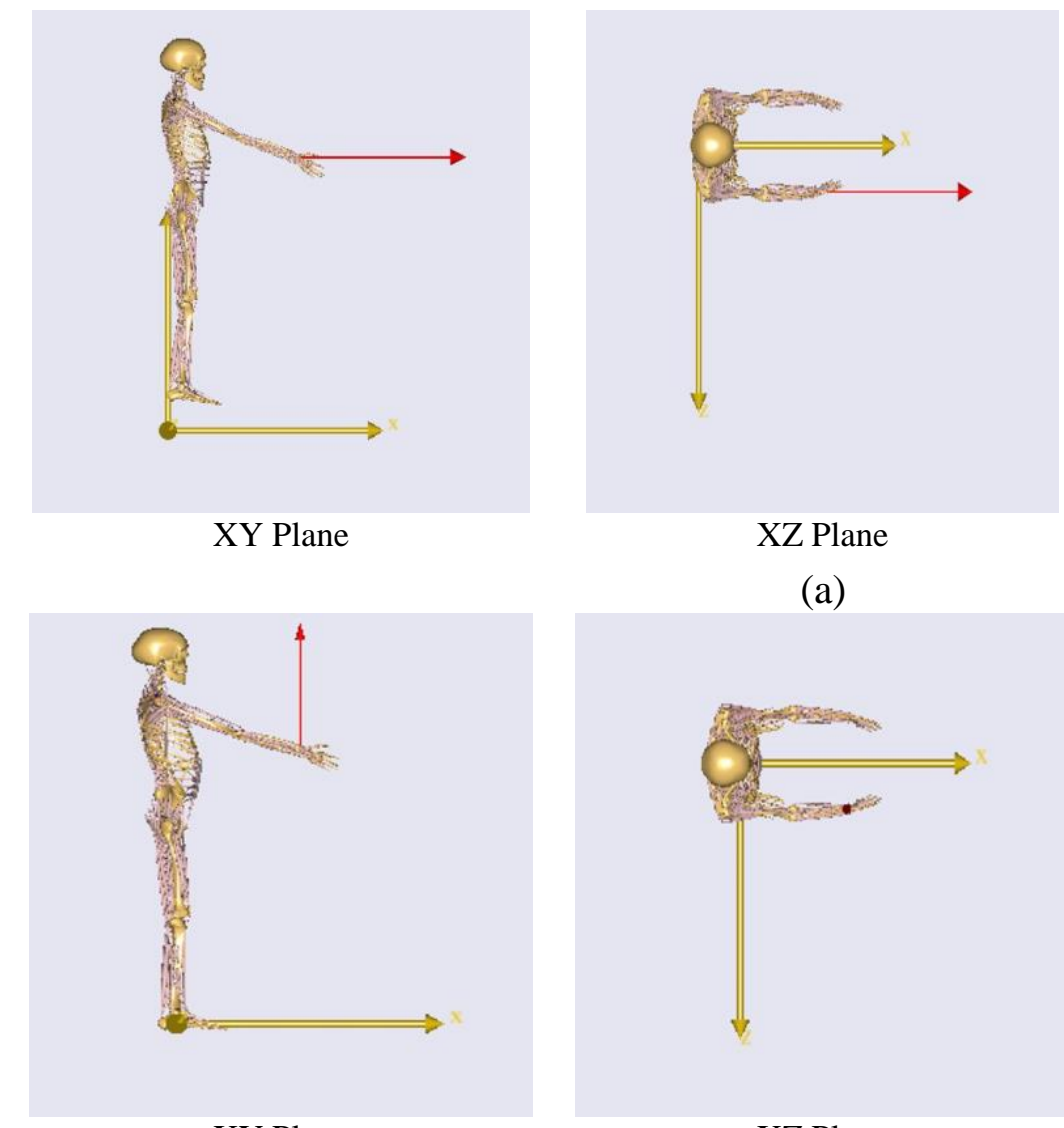

(a)

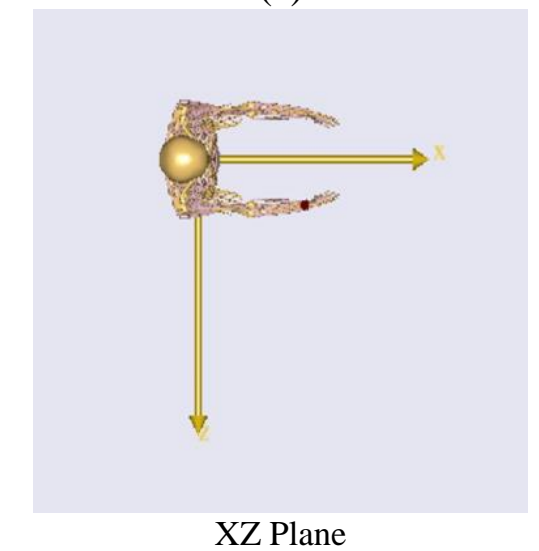

(b)
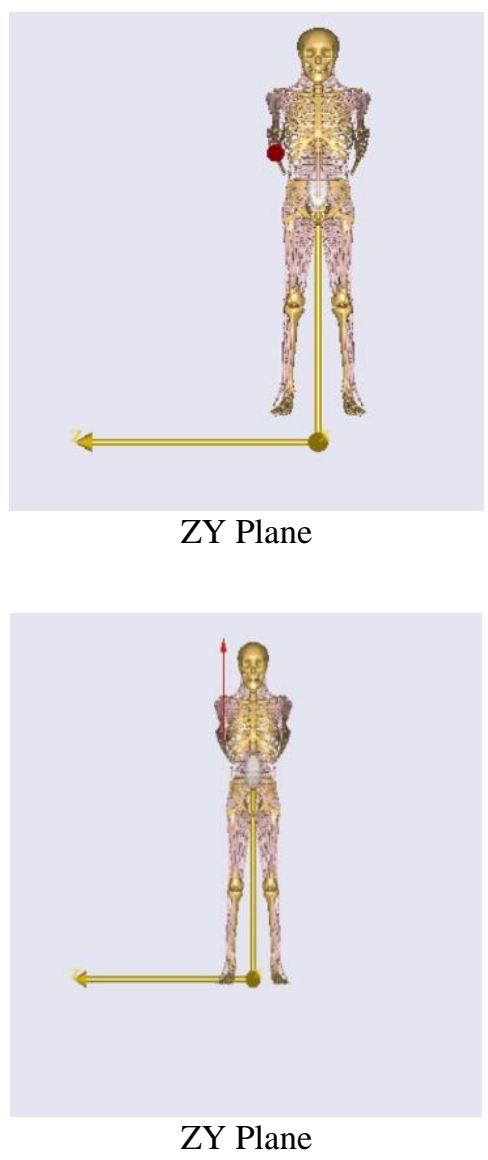


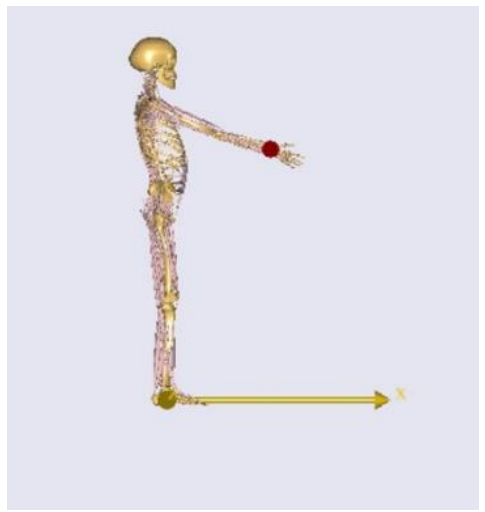

XY Plane

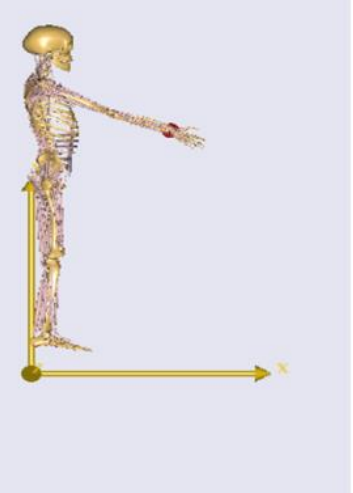

XY Plane

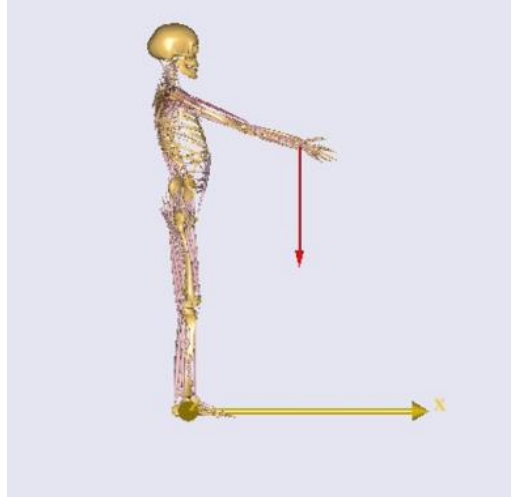

XY Plane

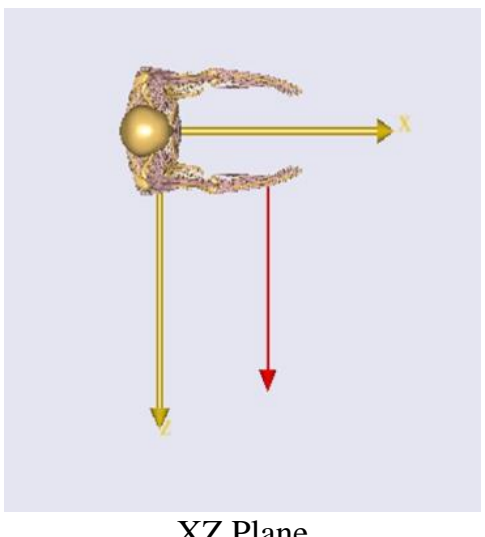

(c)

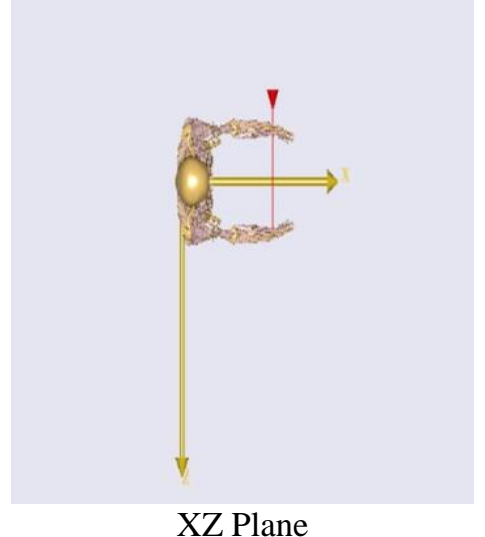

(d)

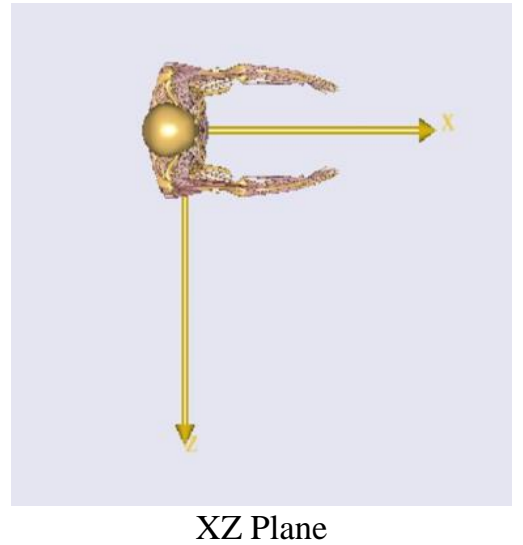

(e)
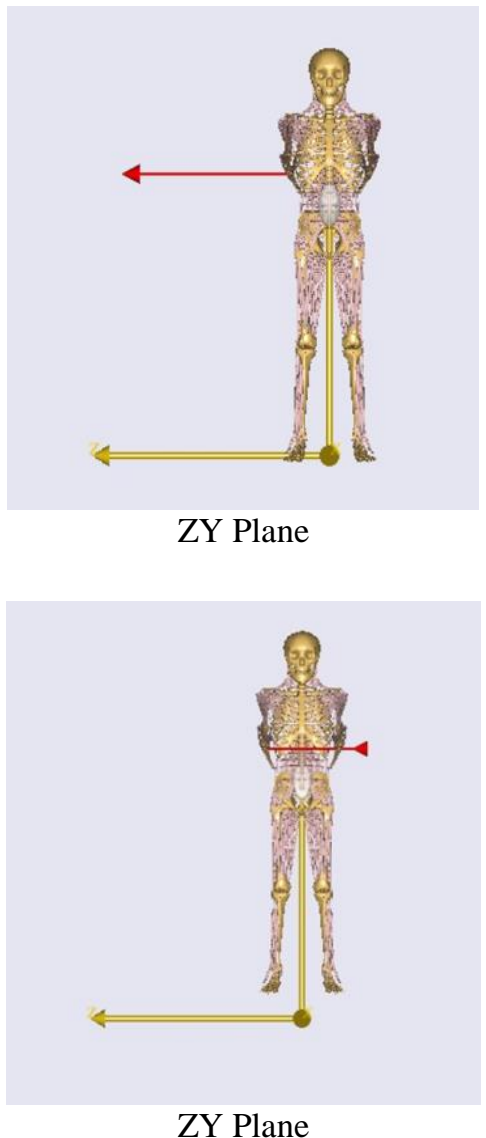

ZY Plane

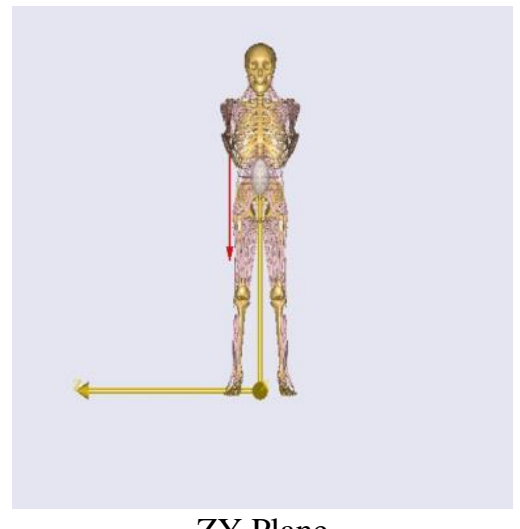

ZY Plane

Figure 4.4 Forceful exertions in sagittal plane with $60^{\circ}$ shoulder angle

The next ten postures were modelled by adjusting the glenohumeral flexion at $45^{\circ}$ (Scapular plane) and glenohumeral abduction at $60^{\circ}$ (Figure 4.5). This posture was used while applying two external force levels $(11.121 \mathrm{~N}$ and $22.242 \mathrm{~N})$ to the right hand of the model. In figure 
4.5, (a) represents the exertion in backward direction, (b) represents the exertions in downward direction, (c) represents the exertions in left direction, (d) represents in right direction and (e) represents the exertions in upward directions.

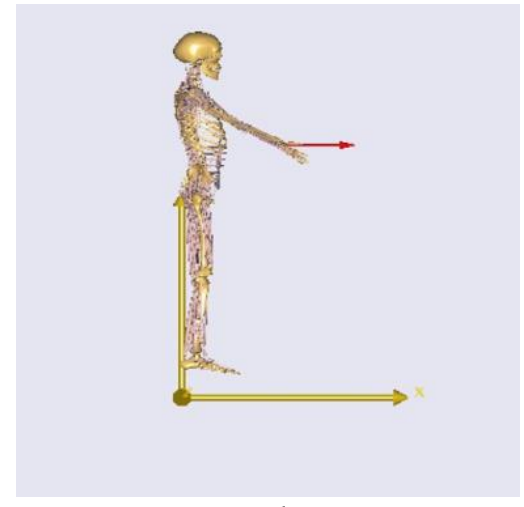

XY Plane

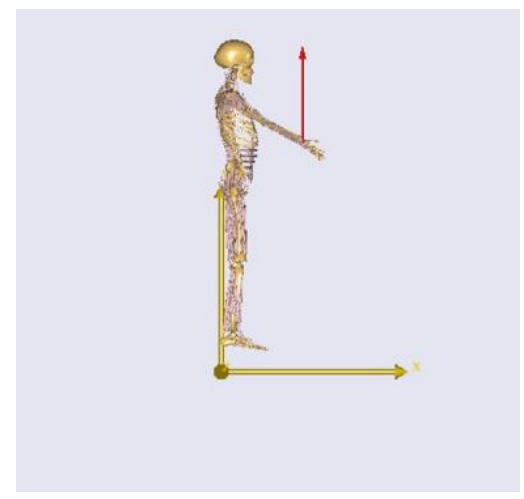

XY Plane

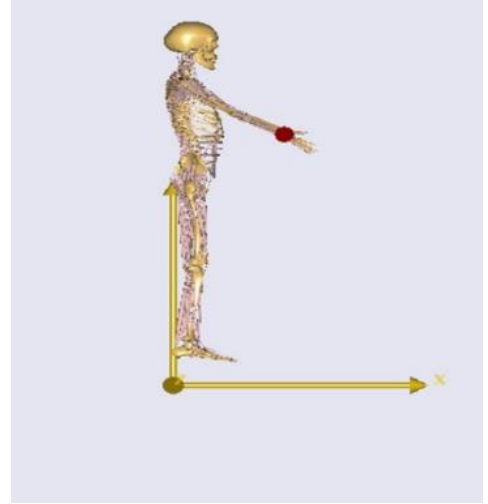

XY Plane

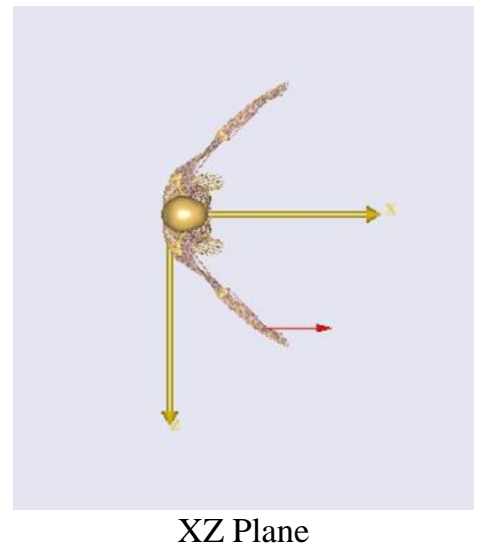

(a)

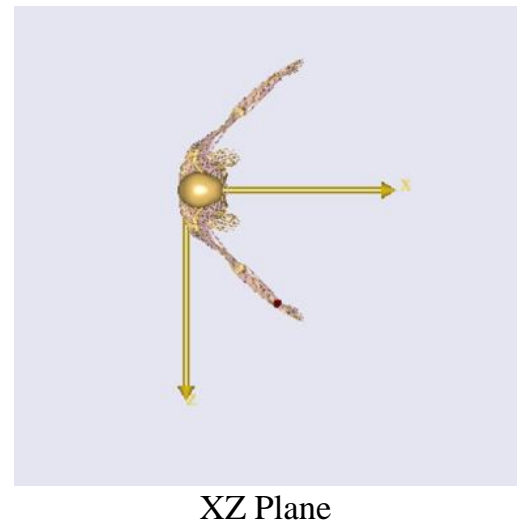

(b)

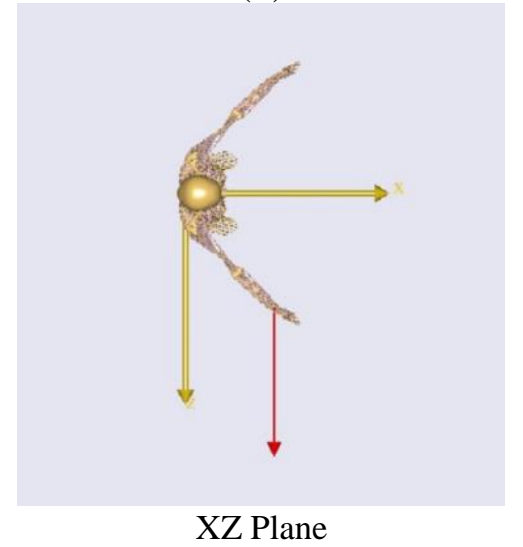

(c)
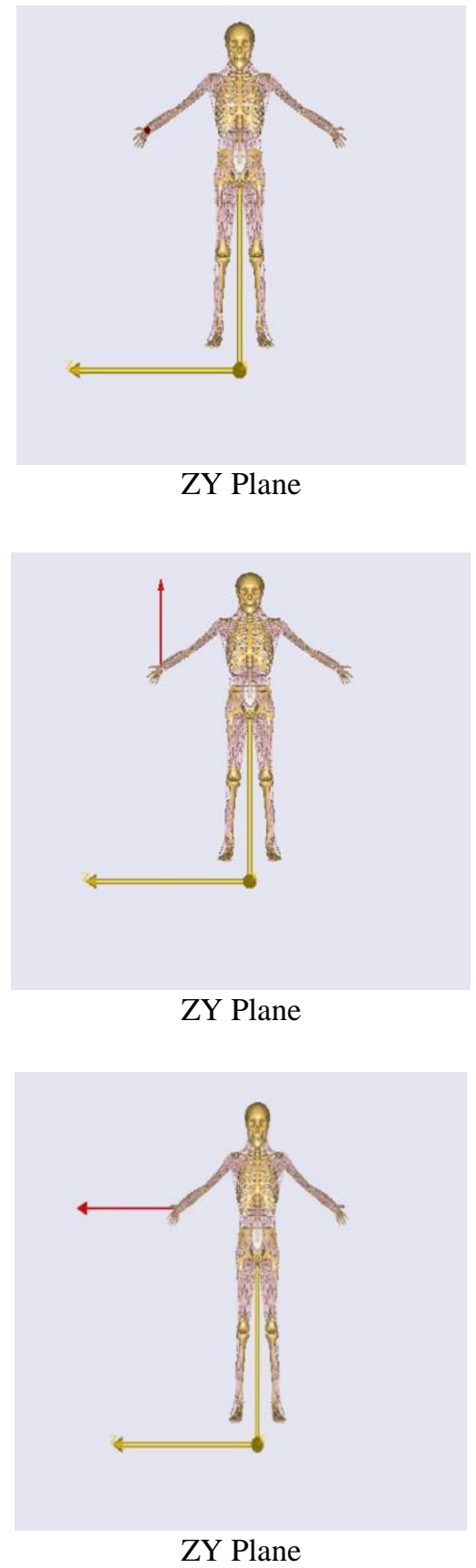

ZY Plane 


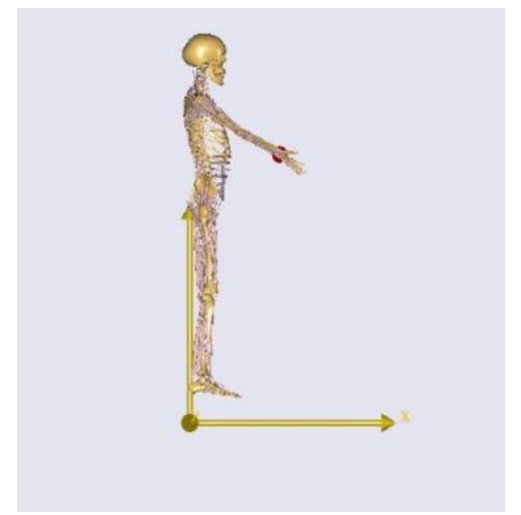

XY Plane

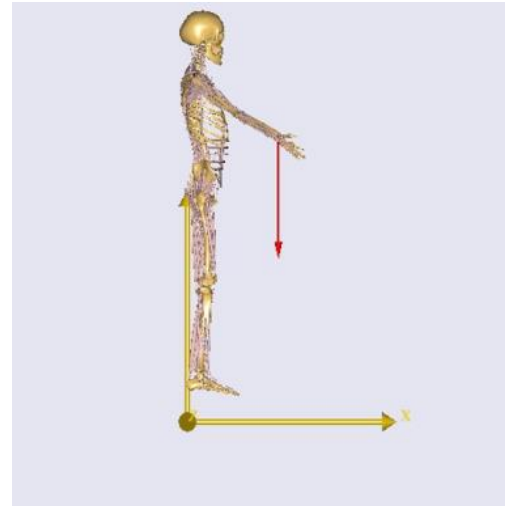

XY Plane

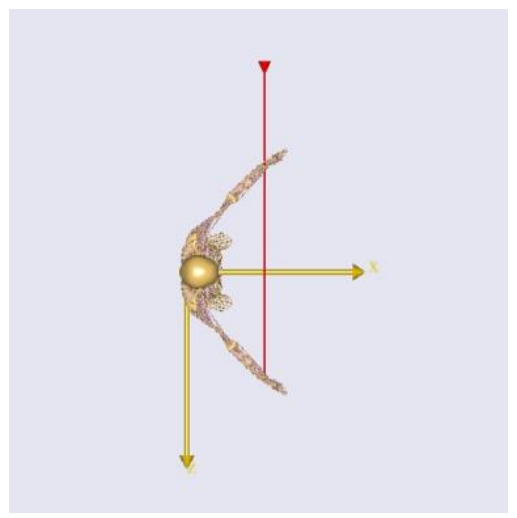

XZ Plane

(d)

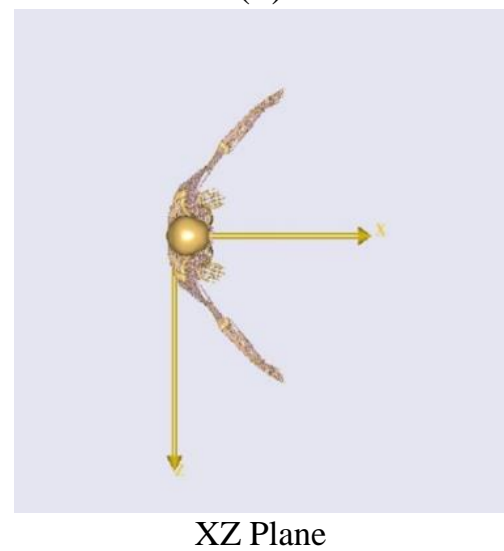

(e)

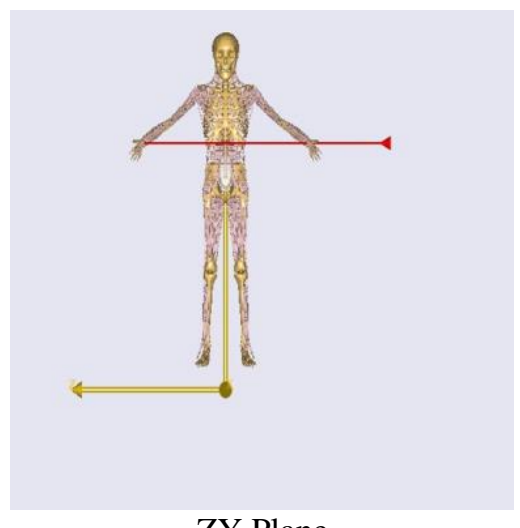

ZY Plane

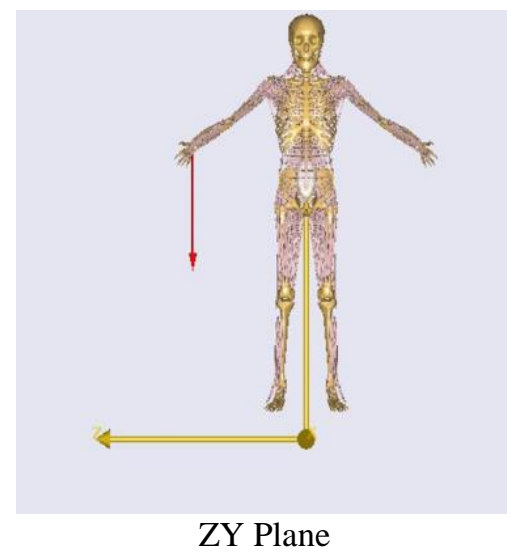

ZY Plane

Figure 4.5 Forceful exertions in scapular plane with $60^{\circ}$ shoulder angle

The next ten postures were modelled by adjusting the glenohumeral flexion at $90^{\circ}$ (Sagittal) and glenohumeral abduction at $120^{\circ}$ (Figure 4.6). This posture was used while applying two external force levels $(11.121 \mathrm{~N}$ and $22.242 \mathrm{~N})$ to the right hand of the model. In figure 4.6, (a) represents the exertion in backward direction, (b) represents the exertions in downward direction, (c) represents the exertions in left direction, (d) represents in right direction and (e) represents the exertions in upward directions. 

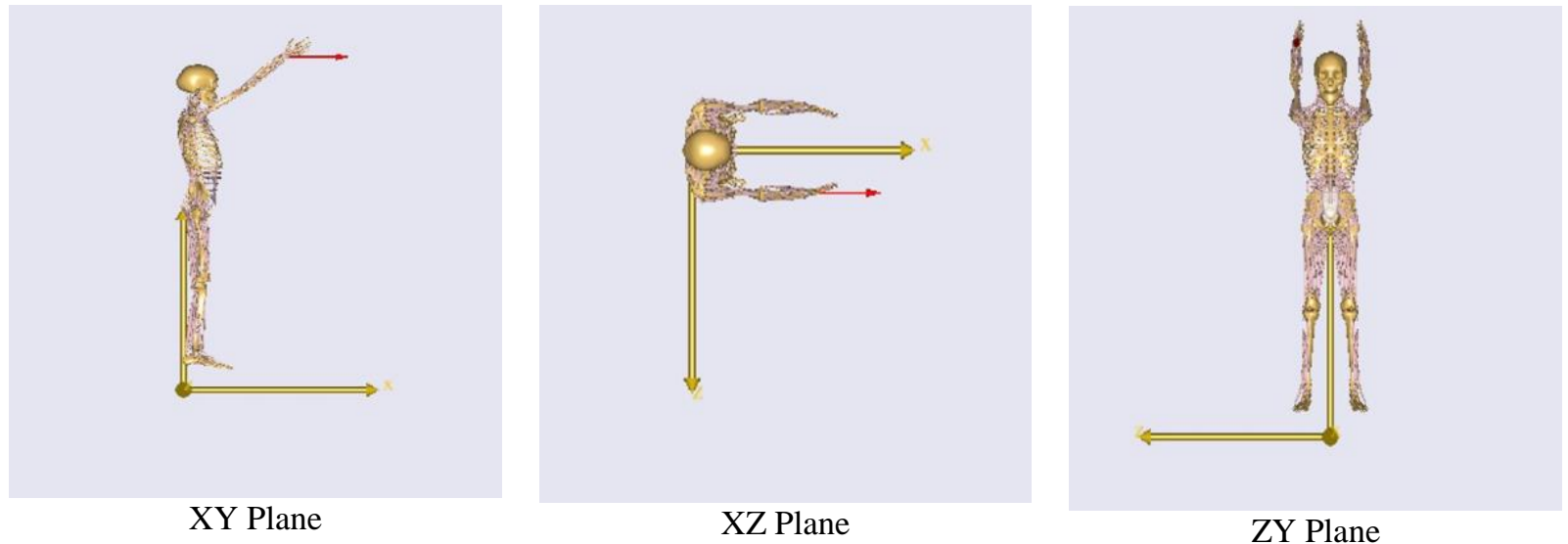

(a)
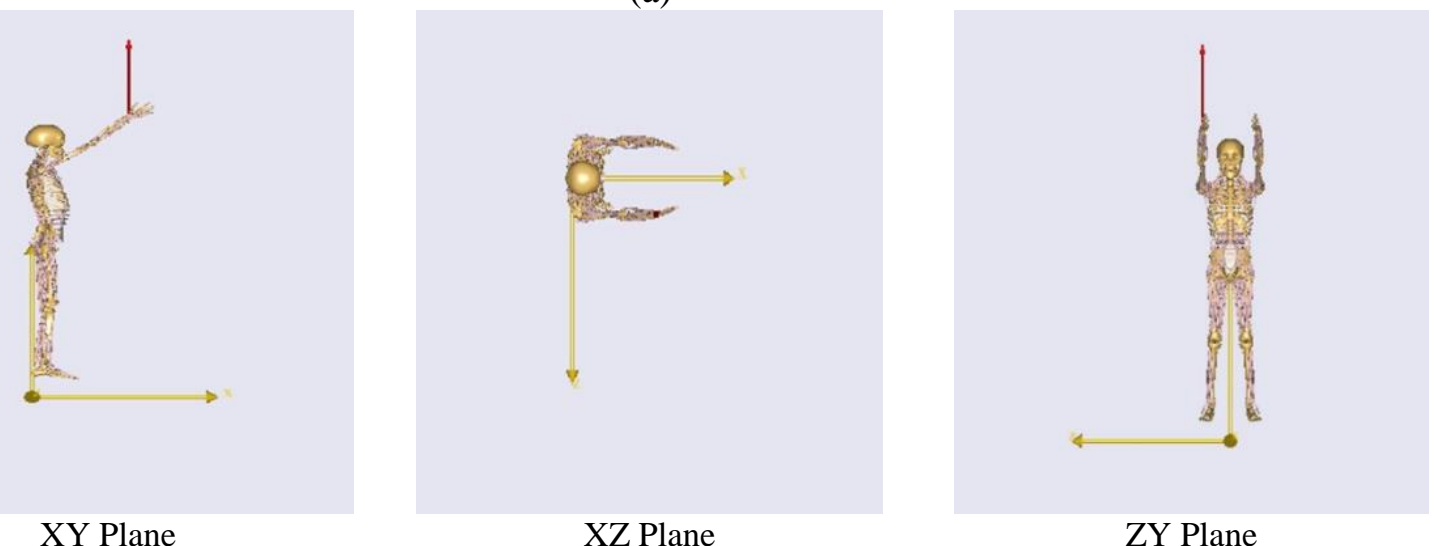

(b)
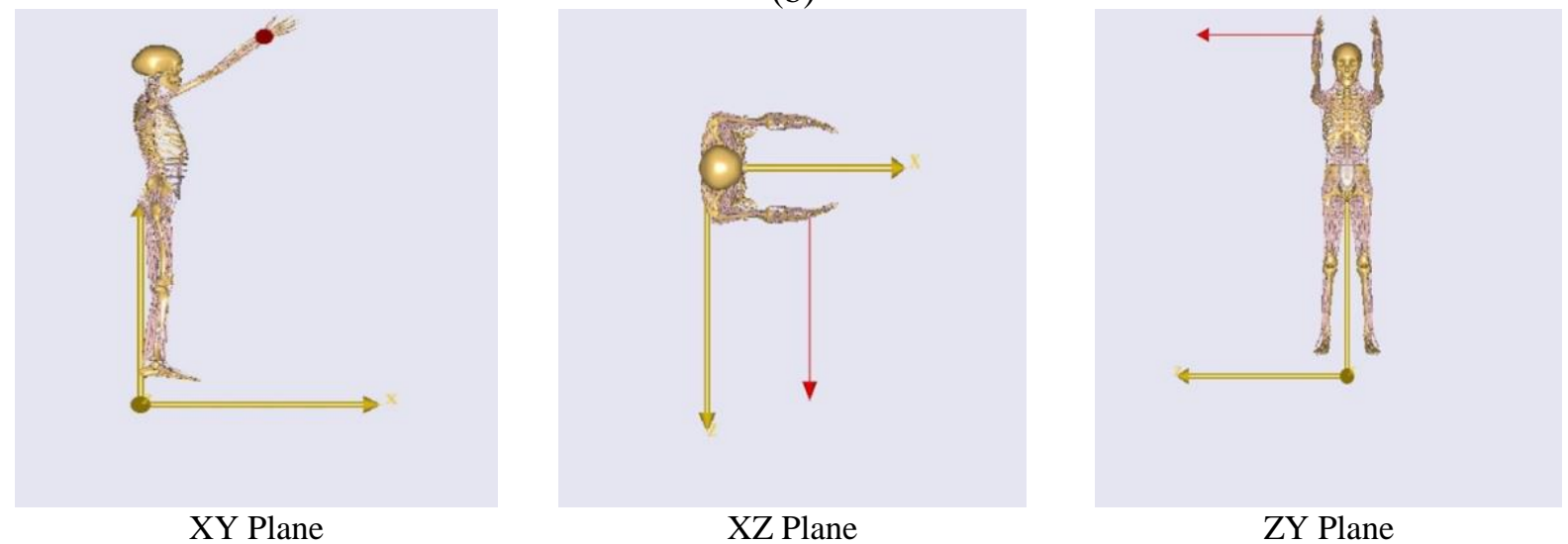

(c) 


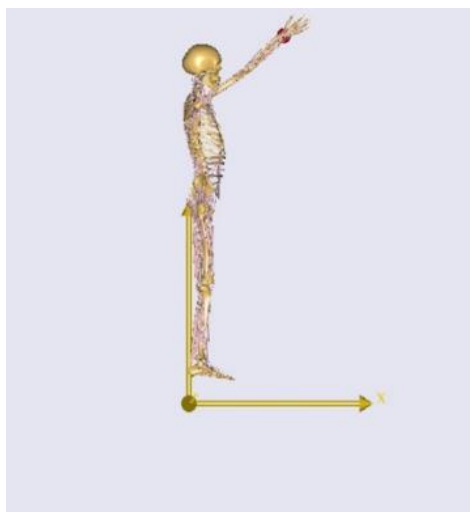

XY Plane

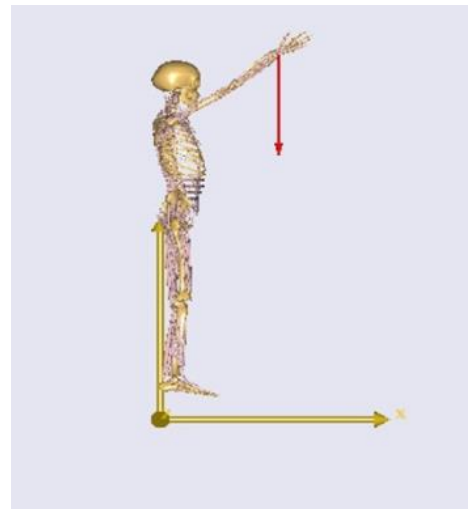

XY Plane

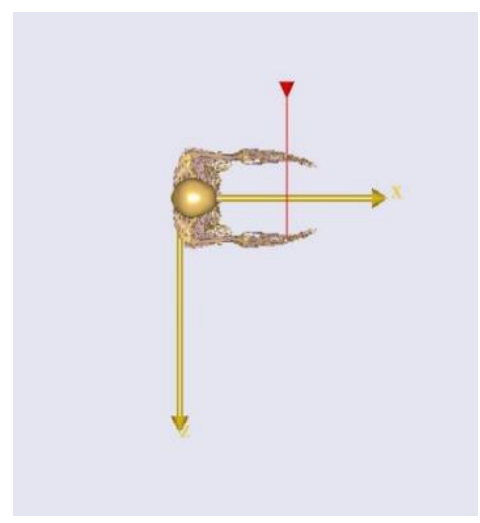

XZ Plane

(d)

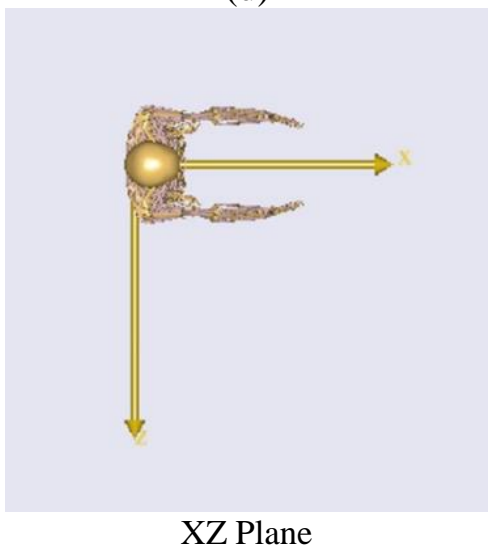

(e)
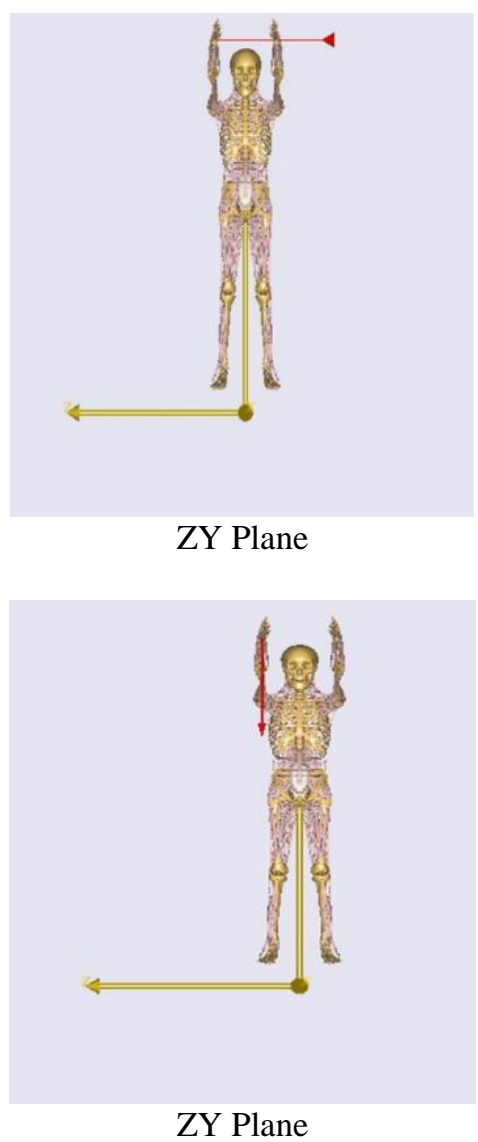

Figure 4.6 Forceful exertions in sagittal plane with $120^{\circ}$ shoulder angle

The succeeding ten postures were modelled by adjusting the glenohumeral flexion at $45^{\circ}$ (Scapular plane) and glenohumeral abduction at $120^{\circ}$ (Figure 4.7). This posture was used while applying two external force levels $(11.121 \mathrm{~N}$ and $22.242 \mathrm{~N})$ to the right hand of the model. In figure 4.7, (a) represents the exertion in backward direction, (b) represents the exertions in downward direction, (c) represents the exertions in left direction, (d) represents in right direction and (e) represents the exertions in upward directions. 

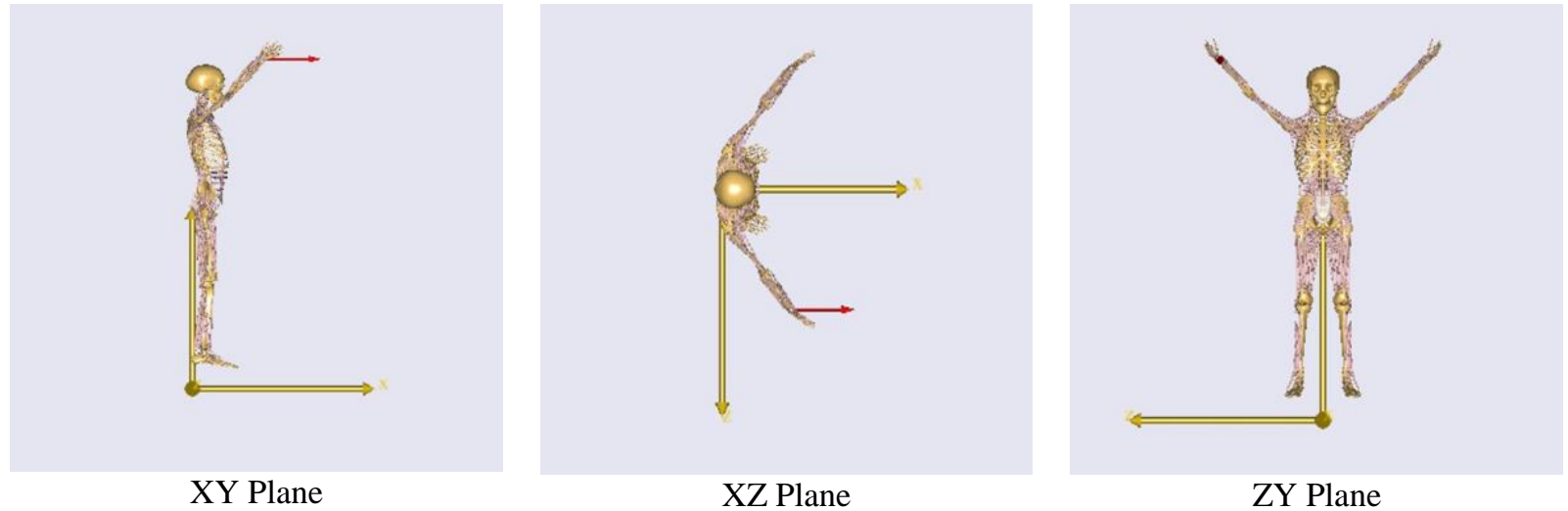

(a)

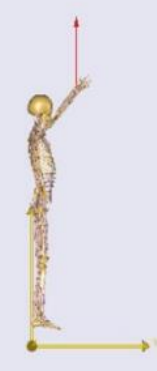

XY Plane
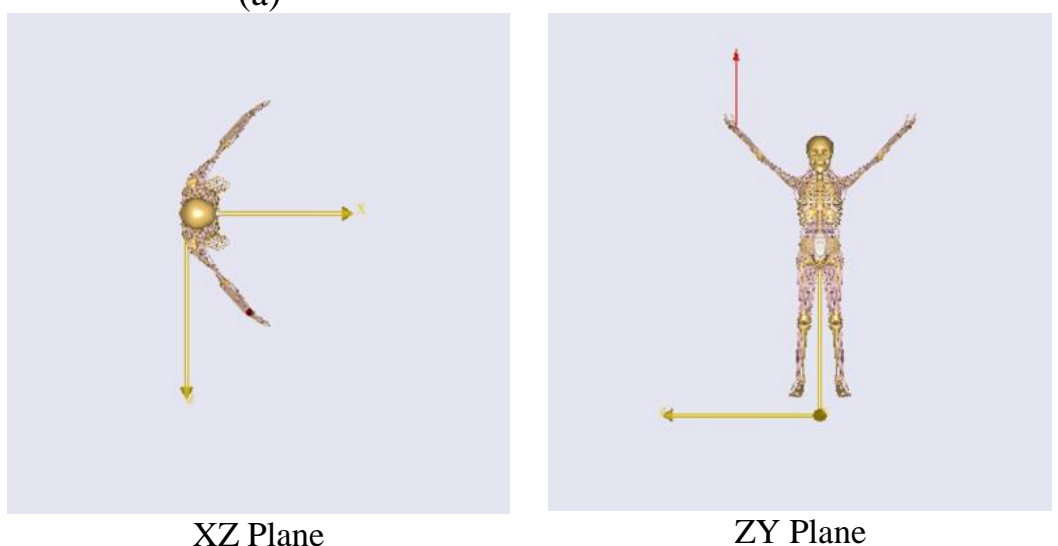

(b)
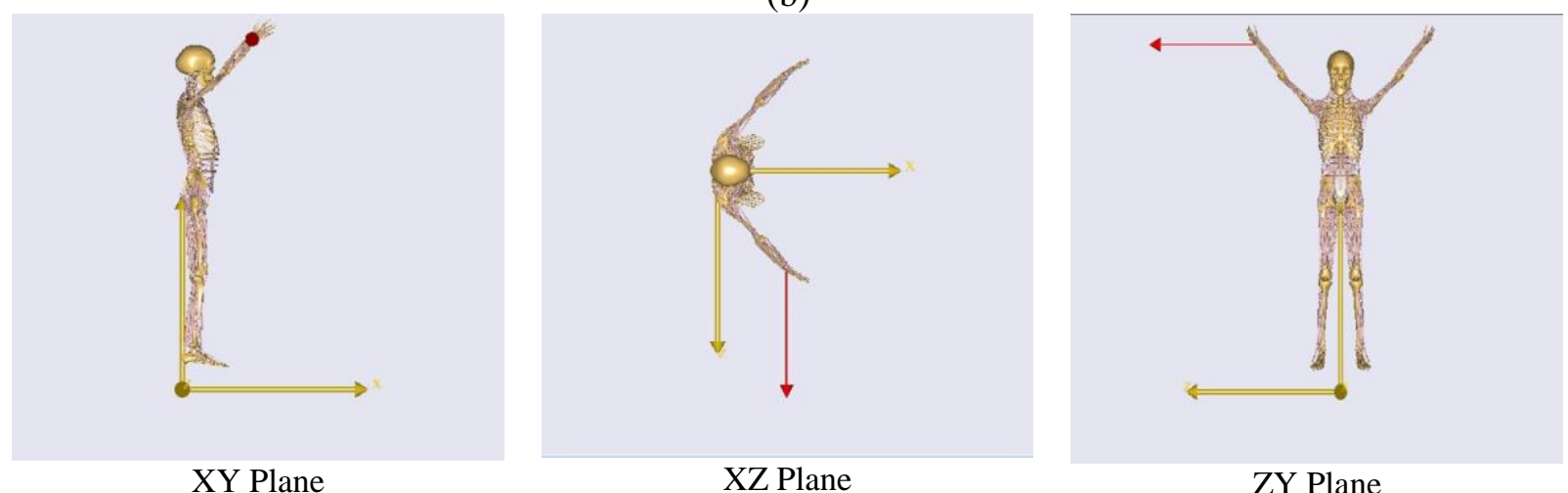

(c)

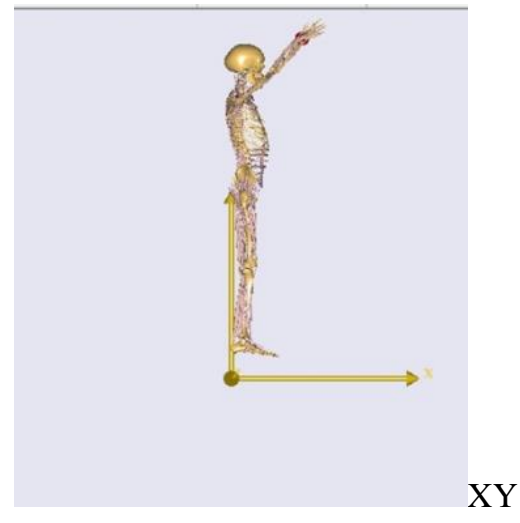

Plane

XY
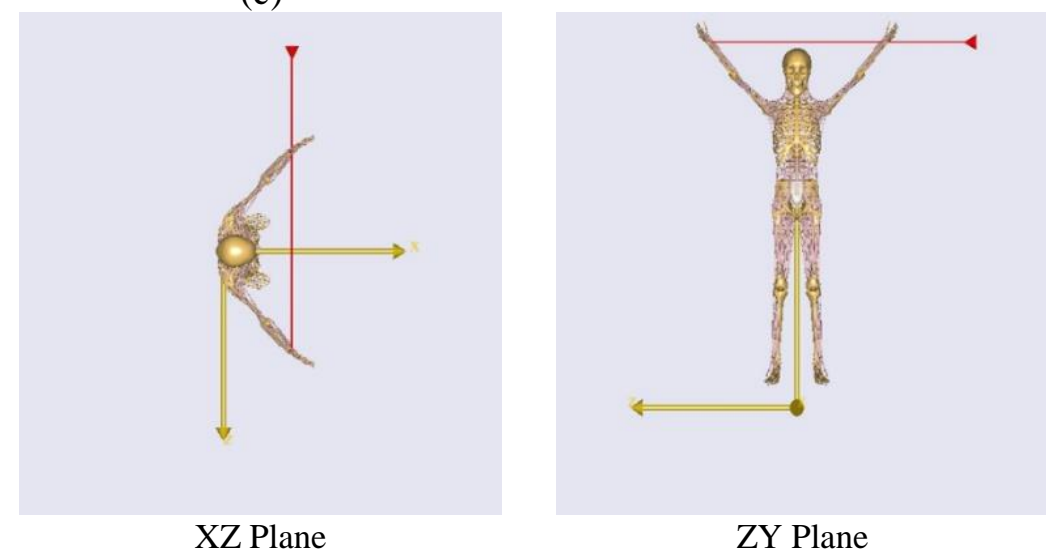
(d)

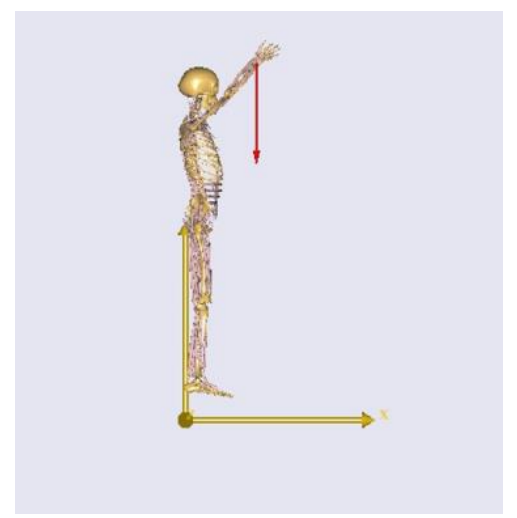

XY Plane

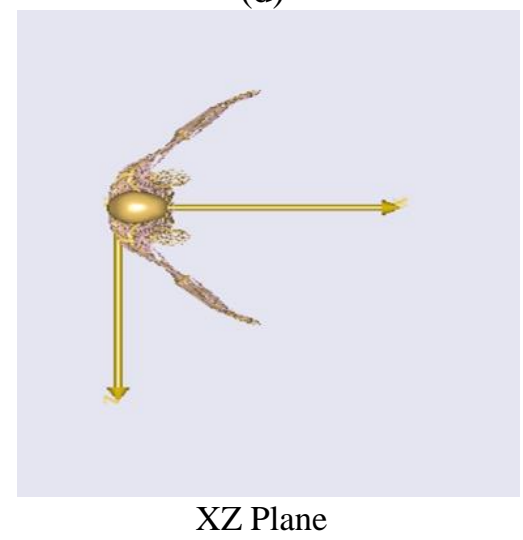

(e)

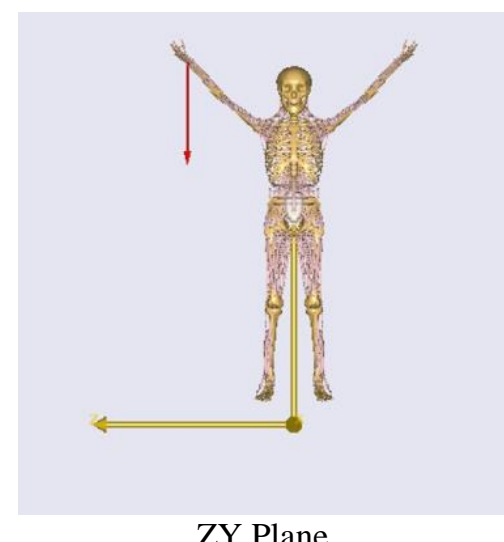

ZY Plane

Figure 4.7 Forceful exertions in scapular plane with $120^{\circ}$ shoulder angle

\subsection{Data Processing}

The modelling analysis was performed to estimate internal reaction forces for the glenohumeral joint. The reaction and the muscle forces required to generate motion or sustain body posture were computed using inverse-dynamic methods by solving a multi-body dynamics problem. The muscle recruitment in the inverse dynamics process were solved using polynomial optimization within which the objective function was to get more synergy and distribute the load evenly between the muscles. The polynomial recruitment pattern allows the organism to carry larger loads without overloading any individual muscle. Based on the anthropometric data of the participants, the standing models were scaled and subsequently forty conditions $(2$ external load $\times$ 2 shoulder angle $\times 2$ shoulder plane $\times 5$ direction) were loaded and simulated in AnyBody Modeling System $^{\mathrm{TM}}$ for 10 seconds. Additionally, maximum isometric exertions (MIE) were performed for each model. After completing the inverse kinematics analysis, the internal joint reaction forces of the right shoulder complex in the three anatomical directions (distraction, inferior-superior, and anterior-posterior) were obtained. The mean of the forces during the force exertion period were used for further calculation of the shoulder strain index. 


\subsubsection{Shoulder Strain Index Calculation}

The shoulder strain index estimates the strain placed on the glenohumeral joint during forceful arm exertions. It was developed based on the relationship between the compressive and translational forces in the shoulder joint. When an external force is applied to the hand, the joint reaction forces in the inferior-superior and anterior-posterior direction moves the humeral head away from the glenoid cavity and destabilizes the shoulder joint. On the other hand, the reaction forces in the medial-lateral direction produce a compressive force in order to counteract the external force and thus stabilizes the glenohumeral joint. The reaction forces obtained from the model configuration were positive in the lateral, superior, and posterior directions. As a result, the resultant of lateral-medial and inferior-superior reaction forces was found in the frontal plane (Rf). Therefore, the resultant of medial and anterior-posterior reaction forces was found in the transverse planes (Rt). The resultant forces were calculated using equations 4.1 and 4.2.

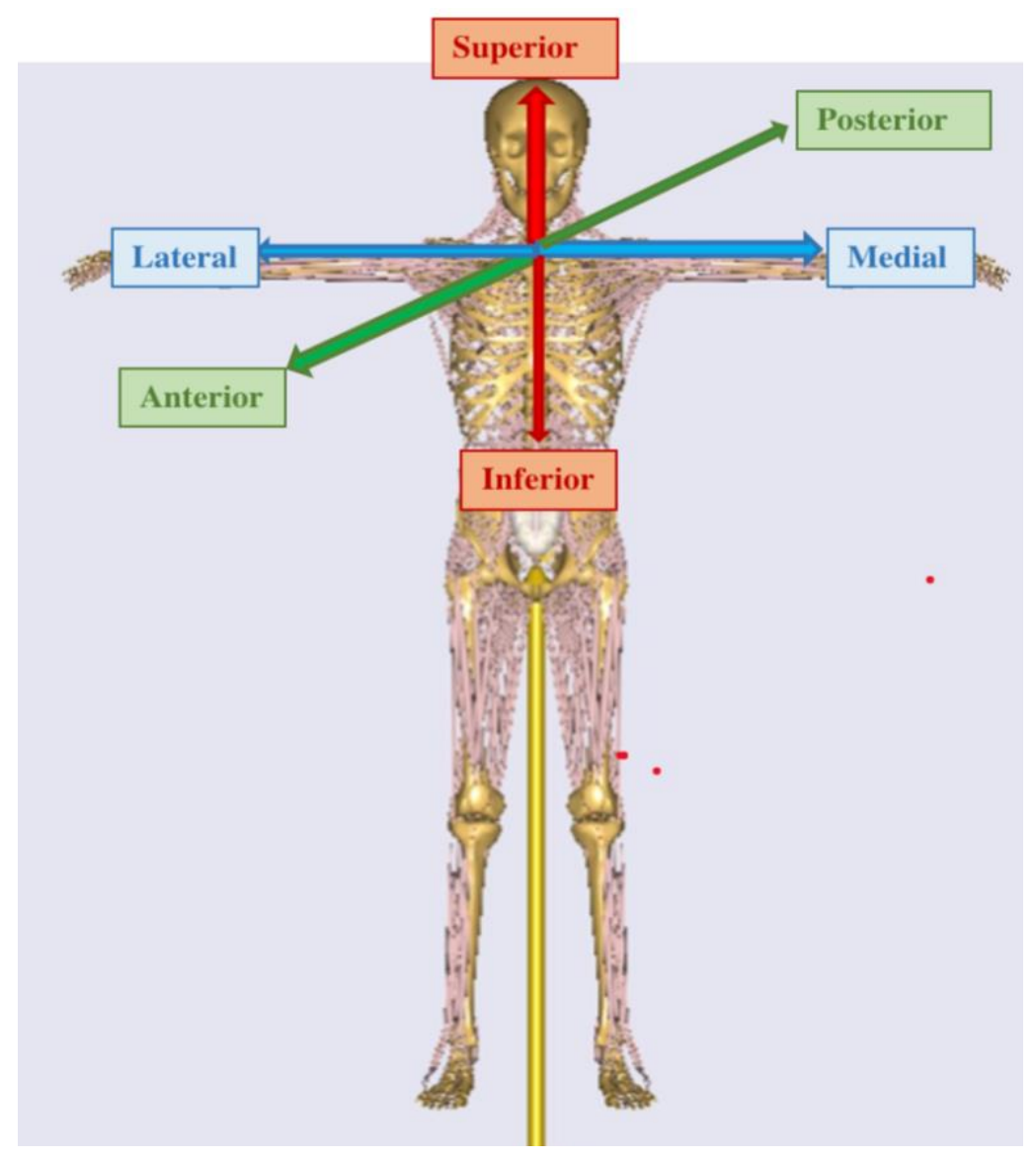

Figure 4.8: Shoulder joint force directions 


$$
\begin{aligned}
& R_{f}=\sqrt{F_{c}^{2}+F_{I / S}^{2}} \\
& R_{t}=\sqrt{F_{c}^{2}+F_{A / P}^{2}}
\end{aligned}
$$

Here, $R_{f}$ is the resultant force acting in the frontal plane, $R_{t}$ is the resultant force acting in the transverse plane, $F_{I / S}$ is the joint reaction force in the interior-superior direction, $F_{A / P}$ is the joint reaction force in the anterior-superior direction, $F_{c}$ is the joint reaction force acting in the lateral direction (Figure 4.9). For calculating the angular displacement of the resultant forces in the frontal and transverse planes, the directions of the resultant forces were used. The angular displacements were calculated using equations 4.3 and 4.4 . 


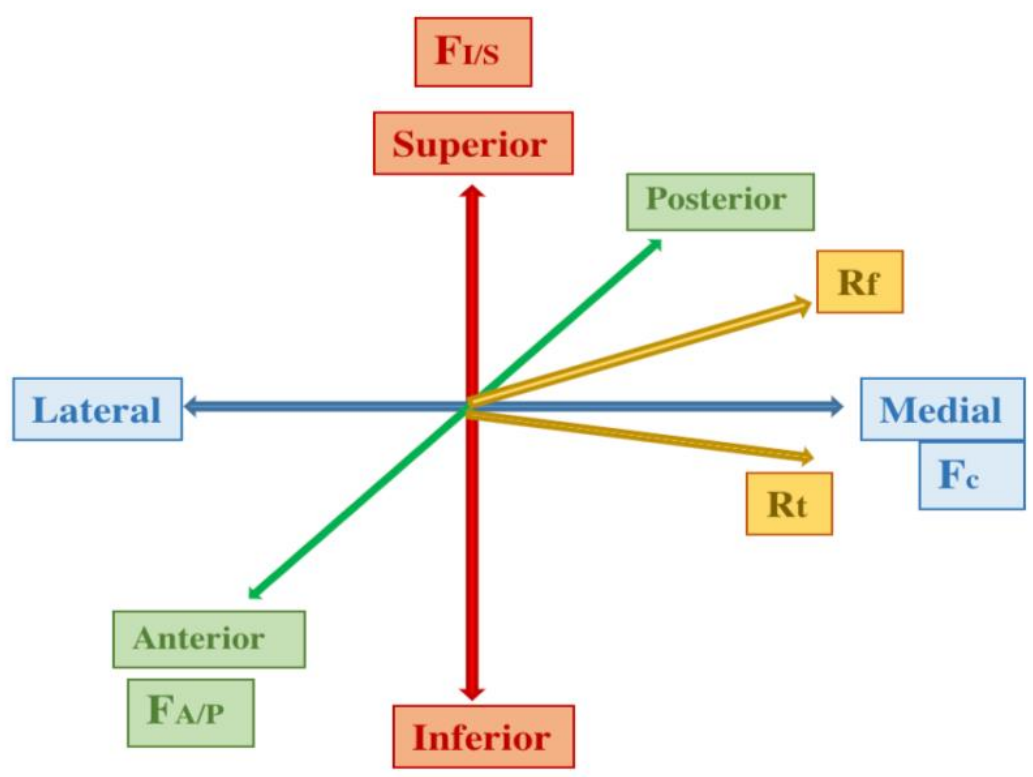

Figure 4.9: Shoulder joint reaction force directions

$$
\begin{aligned}
& \beta=\tan ^{-1} \frac{F_{I / S}}{F_{C}} \\
& \gamma=\tan ^{-1} \frac{F_{A / P}}{F_{C}}
\end{aligned}
$$

Here, $\beta$ is the angular displacement of resultant force in the frontal plane and $\gamma$ is the angular displacement of resultant force in transverse plane.

To reduce the variability between the resultant forces, they were normalized with respect to the resultant reaction force of MIE exertion using equations 4.5 and 4.6 for individual participants. Similarly, the resultant angular displacements of the joint reaction forces were normalized with respect to that maximum angular displacement using equations 4.7 and 4.8. After calculating the normalized values, the shoulder indices for frontal and transverse planes were determined by equations 4.9 and 4.10. The values for frontal and transverse shoulder indices 
should be within a range of 0-50. As these indices might have a positive or negative value, only their absolute values were used for estimating the final shoulder index using equation 4.11.

$$
\begin{gathered}
N_{f}=\frac{R_{f}}{R_{f-M I E}} \\
N_{t}=\frac{R_{t}}{R_{t-M I E}} \\
A_{f}=\frac{\beta}{45} \\
A_{t}=\frac{\gamma}{45} \\
I_{f}=N_{f} \times A_{f} \times 100 . \\
I_{t}=N_{t} \times A_{t} \times 100 . \\
I=\left|I_{f}\right|+\left|I_{t}\right|
\end{gathered}
$$

Here, $N_{f}$ is the normalized resultant reaction force in the frontal plane, $N_{t}$ is the normalized resultant reaction force in the transverse plane, $R_{f-M I E}$ is the resultant reaction force of maximum isometric exertion in the frontal plane, $R_{t-M I E}$ is the resultant reaction force of maximum isometric exertion in the transverse plane, $I_{f}$ is the strain index in the frontal plane, $I_{t}$ is the strain index in the transverse plane and $I$ is the strain index.

The shoulder strain indices for 12 subjects and the average strain indices are shown in Appendix I.

\subsubsection{Statistical Analysis}

General Linear Analysis of Variance (ANOVA) model was used to understand the effect of forceful arm exertions on the strain index. For running the ANOVA model, shoulder angles, shoulder plane, external load and exertion directions were treated as the independent (fixed) factors 
and strain index was treated as a dependent factor. A total of 480 strain index values were used to run the model and two factors interactions were considered. The statistical significance level of $\alpha$ $=0.05$ was used. After finding the significant main and interaction effects, the pairwise comparisons of means were conducted using student's t-test. To quantify the strength of relationship between model-based strain index and the physiological strain (estimated using the muscle activity), correlation analysis was performed. The correlation analysis was performed between (i) strain index data and the activity of individual muscle (local muscle demand); (ii) strain index data and the total shoulder activity (global shoulder joint demand). 


\section{Chapter 5: Results}

\subsection{Effect of Forceful Arm Exertions on Strain Index (SI)}

The effect of shoulder angle $(\mathrm{p}=0.0015)$, shoulder plane $(\mathrm{p}<0.0001)$, external force $(\mathrm{p}<0.0001)$ and exertion direction $(\mathrm{p}<0.0001)$ on strain index was statistically significant. The Fratio and p-values for the main and interaction effects of the five factors on SI are shown in Table 5.1. The interaction effects between shoulder angle and shoulder plane $(\mathrm{p}<0.0001)$, shoulder angle and external force $(\mathrm{p}=0.0198)$, shoulder angle and exertion direction $(\mathrm{p}<0.0001)$, shoulder plane and external force $(\mathrm{p}=0.0307)$, shoulder plane and exertion direction $(\mathrm{p}<0.0001)$ and external force and exertion direction $(\mathrm{p}<0.0001)$ were found to be statistically significant.

Table 5.1 ANOVA test results

\begin{tabular}{|c|c|c|}
\hline \multicolumn{3}{|c|}{ Main effect } \\
\hline Source & F Ratio & Prob > F \\
\hline Shoulder Angle & 10.1497 & $0.0015^{*}$ \\
\hline Shoulder Plane & 367.3435 & $<.0001^{*}$ \\
\hline External Force (lb) & 431.7706 & $<.0001^{*}$ \\
\hline Exertion direction & 1141.309 & $<.0001^{*}$ \\
\hline \multicolumn{2}{|c|}{ Interaction effect } \\
\hline Source & F Ratio & Prob > F \\
\hline Shoulder Angle*Shoulder Plane & 90.2889 & $<.0001^{*}$ \\
\hline Shoulder Angle*External Force (lb) & 5.4675 & $0.0198^{*}$ \\
\hline Shoulder Angle*Exertion direction & 46.9828 & $<.0001^{*}$ \\
\hline Shoulder Plane*External Force (lb) & 4.6989 & $0.0307^{*}$ \\
\hline Shoulder Plane*Exertion direction & 27.3401 & $<.0001^{*}$ \\
\hline External Force (lb)*Exertion direction & 49.0608 & $<.0001^{*}$ \\
\hline
\end{tabular}

* Means statistically significant

Statistically significant main and interaction effects were subjected to post hoc comparison using student's $t$ test. The student's $t$ test results along with the means for the levels of different 
factors are shown in Table 5.2 and 5.3. The connecting letters next to level within a factor indicate that the levels that do not share the same letter are statistically significantly different from each other at $\alpha=0.05$. Figure 5.1 and 5.2 represents the mean and $95 \%$ Confidence Interval (CI) of strain indices at all levels and combinations of the levels of the treatment factors, respectively.

Table 5.2 Pairwise comparison of student's t test (factor levels)

\begin{tabular}{|c|c|c|c|c|c|}
\hline $\begin{array}{c}\text { Factor } \\
\text { (Independent } \\
\text { variable) }\end{array}$ & Level & $\begin{array}{c}\text { Connecting } \\
\text { Letters }\end{array}$ & Mean & $\mathbf{t}$ ratio & Prob $>\mid \mathbf{t}$ \\
\hline \multirow{2}{*}{ Shoulder Angle } & $120^{\circ}$ & $\mathrm{A}$ & 17.16 & 3.20 & 0.0015 \\
\hline & $60^{\circ}$ & $\mathrm{B}$ & 16.36 & -3.20 & 0.0015 \\
\hline \multirow{2}{*}{ Shoulder Plane } & Sagittal & $\mathrm{A}$ & 19.16 & 19.25 & $<0.0001$ \\
\hline & Scapula & $\mathrm{B}$ & 14.36 & -19.25 & $<0.0001$ \\
\hline \multirow{2}{*}{ External Force (lb) } & 5 & $\mathrm{~A}$ & 19.36 & 20.87 & $<0.0001$ \\
\hline & 2.5 & $\mathrm{~B}$ & 14.16 & -20.87 & $<0.0001$ \\
\hline \multirow{5}{*}{ Exertion Direction } & $\mathrm{PU}$ & $\bar{A}$ & 30.86 & 56.55 & $<0.0001$ \\
\hline & $\mathrm{PL}$ & $\mathrm{B}$ & 17.17 & 1.62 & 0.1054 \\
\hline & PR & B & 16.82 & 0.23 & 0.8166 \\
\hline & $\mathrm{PB}$ & $\mathrm{C}$ & 14.62 & -8.59 & $<0.0001$ \\
\hline & $\mathrm{PD}$ & $\mathrm{D}$ & 4.34 & -49.81 & $<0.0001$ \\
\hline
\end{tabular}

From the student's t test, it was found that the mean shoulder strain index at $120^{\circ}$ shoulder angle was significantly higher than the mean shoulder strain index at $60^{\circ}$ shoulder angle. The mean values of the SI were 17.16 and 16.36 respectively. These values with $95 \% \mathrm{CI}$ are shown on figure 5.1 (a). 
The student's $\mathrm{t}$ test also revealed that the sagittal plane generated a significantly higher mean strain index than the scapular plane. The mean strain indices of sagittal plane and scapular plane are 19.16 and 14.36. Figure 5.1 (b) represents these values with 95\% CI.

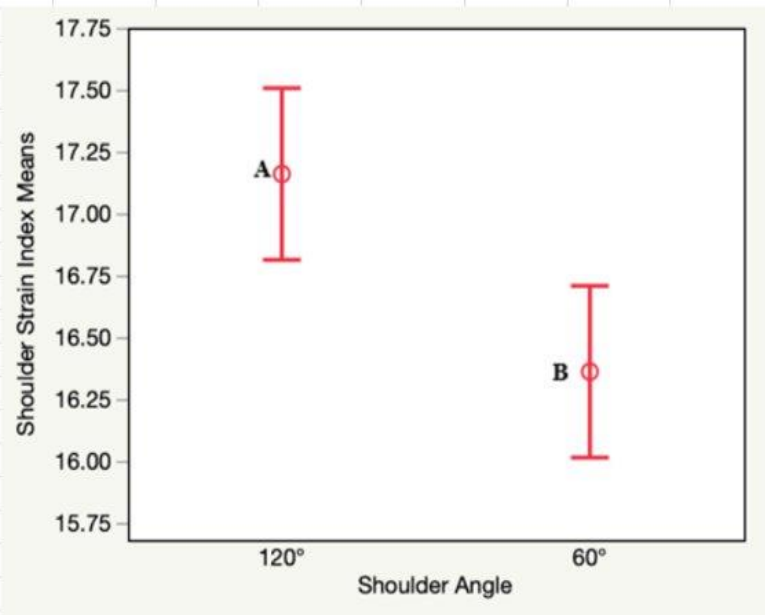

(a)

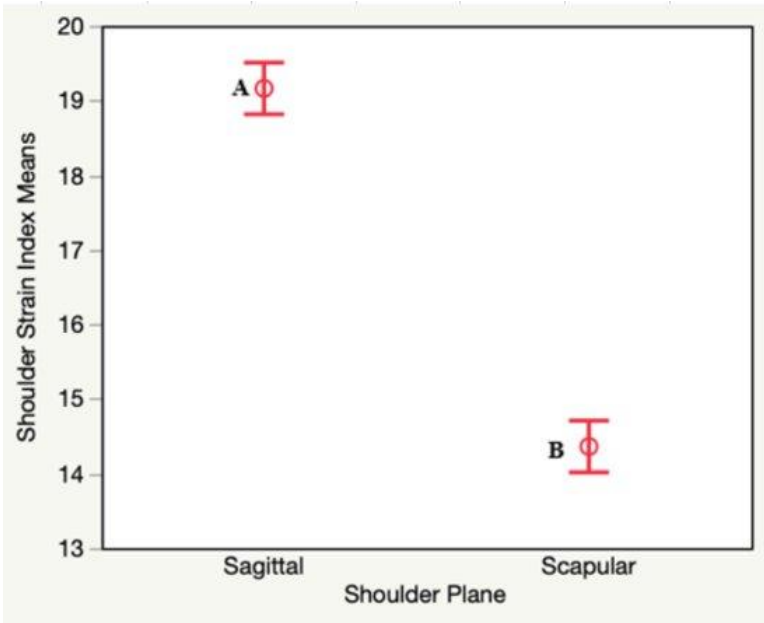

(b)

Figure 5.1: Mean and 95\% CI for all combinations of main factors

Student's $t$ test for external force levels showed that the mean strain index at $5 \mathrm{lb}$ was significantly higher than at $2.5 \mathrm{lb}$ load. The mean strain index for $5 \mathrm{lb}$ load was 19.36 and the mean strain index for $2.5 \mathrm{lb}$ was 14.16 . Figure 5.1 (c) represents these values with 95\% CI.

From the student's t-test it was found that the mean strain index for pulling up task was significantly higher compared to pulling left, pushing right, pulling back and pulling down tasks. The magnitude of the mean strain index of pulling up was 30.86. Additionally, the strain indices for pulling left and pushing right directions were larger than pulling back and pulling down tasks. However, the difference between pulling left and right was not significant. The mean strain index for pulling left and right was 17.17 and 16.82. It was also noticed that pulling back and pulling down tasks were significantly different from each other with mean strain index values of 14.62 and 4.34, respectively. Figure 5.1 (d) shows these values with 95\% CI. 


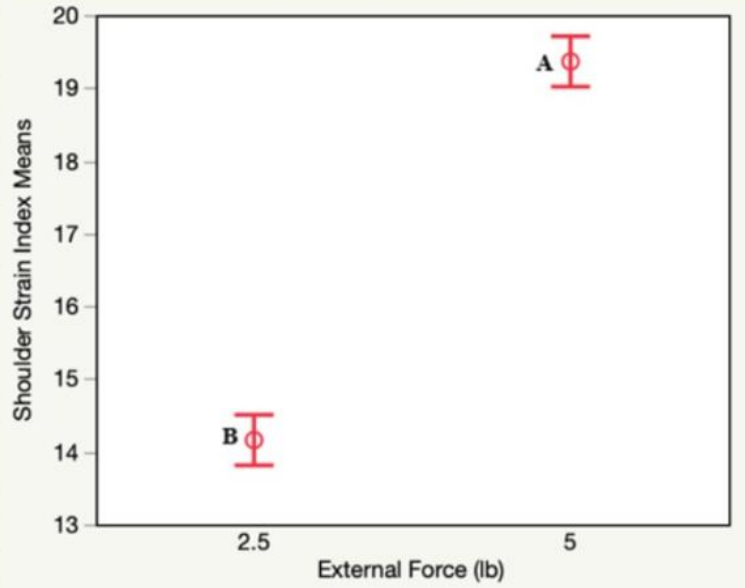

(c)

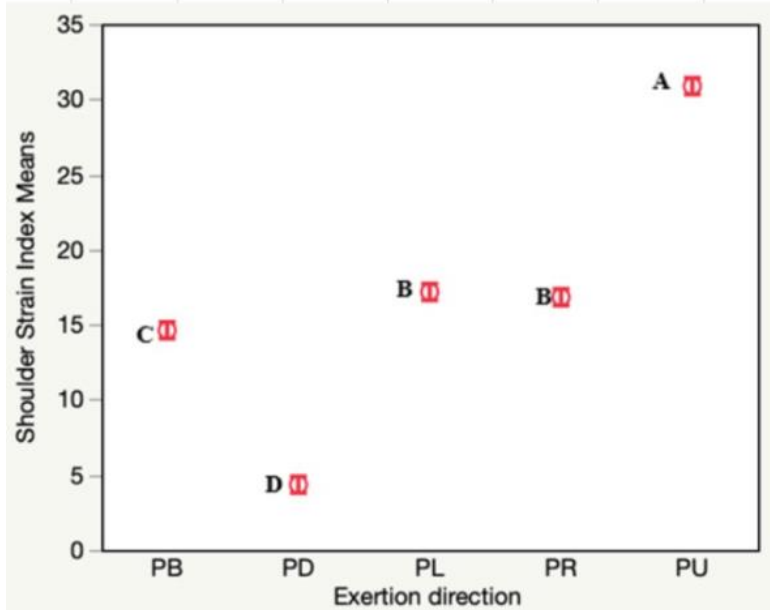

(d)

Figure 5.2: Mean and 95\% CI for all combinations of main factors (Continued)

The results of pairwise comparisons based on the student's t test for the interaction effect are summarized in Table 5.3.

Table 5.3 Pairwise comparison of student's t test (combination of factor levels)

\begin{tabular}{|c|c|c|c|c|c|}
\hline $\begin{array}{c}\text { Factor } \\
\text { (Combination } \\
\text { of independent } \\
\text { variables) }\end{array}$ & Level & $\begin{array}{c}\text { Connecting } \\
\text { Letters }\end{array}$ & Mean & t ratio & Prob>|t \\
\hline \multirow{2}{*}{$\begin{array}{c}\text { Shoulder } \\
\text { Angle*Shoulder } \\
\text { Plane }\end{array}$} & $120^{\circ}$, Sagittal & $\mathrm{A}$ & 20.75 & 9.54 & $<0.0001$ \\
\cline { 2 - 6 } & $60^{\circ}$, Sagittal & $\mathrm{B}$ & 17.57 & -9.54 & $<0.0001$ \\
\cline { 2 - 6 } & $60^{\circ}$, Scapular & $\mathrm{C}$ & 15.15 & 9.54 & $<0.0001$ \\
\cline { 2 - 6 } & $120^{\circ}$, Scapular & $\mathrm{D}$ & 13.57 & -9.54 & $<0.0001$ \\
\hline \multirow{2}{*}{$\begin{array}{c}\text { Shoulder } \\
\text { Angle*External } \\
\text { Force Level }\end{array}$} & $120^{\circ}, 5$ & $\mathrm{~A}$ & 20.06 & 2.35 & 0.0193 \\
\cline { 2 - 6 } & $60^{\circ}, 5$ & $\mathrm{~B}$ & 18.67 & -2.35 & 0.0193 \\
\cline { 2 - 6 } & $120^{\circ}, 2.5$ & $\mathrm{C}$ & 14.27 & -2.35 & 0.0193 \\
\hline \multirow{2}{*}{$\begin{array}{c}\text { Shoulder } \\
\text { Angle*Extion } \\
\text { direction }\end{array}$} & $60^{\circ}, \mathrm{PU}$ & $\mathrm{C}$ & 14.05 & 2.35 & 0.0193 \\
\cline { 2 - 6 } & $120^{\circ}, \mathrm{PU}$ & $\mathrm{A}$ & 32.93 & 9.90 & $<0.0001$ \\
\cline { 2 - 6 } & $120^{\circ}, \mathrm{PR}$ & $\mathrm{B}$ & 28.79 & -9.90 & $<0.0001$ \\
\cline { 2 - 6 } & $60^{\circ}, \mathrm{PL}$ & $\mathrm{C}$ & 18.88 & 6.64 & $<0.0001$ \\
\hline
\end{tabular}


Table 5.3 Pairwise comparison of student's t test (combination of factor levels)

\begin{tabular}{|c|c|c|c|c|c|}
\hline Source & Level & $\begin{array}{c}\text { Connecting } \\
\text { Letters Report }\end{array}$ & Mean & t ratio & Prob $>\mid \mathbf{t}$ \\
\hline \multirow{6}{*}{$\begin{array}{c}\text { Shoulder } \\
\text { Angle*Exertion } \\
\text { direction }\end{array}$} & $120^{\circ}, \mathrm{PB}$ & $\mathrm{D}$ & 17.21 & 8.80 & $<0.0001$ \\
\hline & $120^{\circ}, \mathrm{PL}$ & $\mathrm{D}$ & 16.62 & -3.80 & 0.0002 \\
\hline & $60^{\circ}, \mathrm{PR}$ & $\mathrm{E}$ & 14.76 & -6.64 & $<0.0001$ \\
\hline & $60^{\circ}, \mathrm{PB}$ & $\mathrm{F}$ & 12.03 & -8.80 & $<0.0001$ \\
\hline & $60^{\circ}, \mathrm{PD}$ & $\mathrm{G}$ & 4.38 & 1.75 & 0.0816 \\
\hline & $120^{\circ}, \mathrm{PD}$ & $\mathrm{G}$ & 4.30 & -1.75 & 0.0816 \\
\hline \multirow{4}{*}{$\begin{array}{l}\text { Shoulder Plane* } \\
\text { External Force }\end{array}$} & Sagittal,5 & A & 22.04 & 2.18 & 0.0300 \\
\hline & Scapular,5 & $\mathrm{B}$ & 16.69 & -2.18 & 0.0300 \\
\hline & Sagittal,2.5 & $\mathrm{B}$ & 16.29 & -2.18 & 0.0300 \\
\hline & Scapular,2.5 & $\mathrm{C}$ & 12.03 & 2.18 & 0.0300 \\
\hline \multirow{10}{*}{$\begin{array}{c}\text { Shoulder Plane* } \\
\text { Exertion } \\
\text { Direction }\end{array}$} & Sagittal, PU & $\mathrm{A}$ & 35.45 & 8.75 & $<0.0001$ \\
\hline & Scapular, PU & $\mathrm{B}$ & 26.28 & -8.75 & $<0.0001$ \\
\hline & Sagittal, PL & $\mathrm{C}$ & 20.07 & 2.00 & 0.0461 \\
\hline & Sagittal, PR & $\mathrm{C}$ & 19.16 & -0.23 & 0.8216 \\
\hline & Sagittal, PB & $\mathrm{D}$ & 15.95 & -4.30 & $<0.0001$ \\
\hline & Scapular, PR & $\mathrm{E}$ & 14.48 & 0.23 & 0.8216 \\
\hline & Scapular, PL & $\mathrm{EF}$ & 14.27 & -2.00 & 0.0461 \\
\hline & Scapular, PB & $\mathrm{F}$ & 13.29 & 4.30 & 0.0001 \\
\hline & Sagittal, PD & $\mathrm{G}$ & 5.19 & -6.22 & $<0.0001$ \\
\hline & Scapular, PD & $\mathrm{H}$ & 3.49 & 6.22 & $<0.0001$ \\
\hline \multirow{10}{*}{$\begin{array}{c}\text { External Force } \\
\text { (lb)*Exertion } \\
\text { Direction }\end{array}$} & $5, \mathrm{PU}$ & A & 36.89 & 13.77 & $<0.0001$ \\
\hline & $2.5, \mathrm{PU}$ & $\mathrm{B}$ & 24.83 & -13.77 & $<0.0001$ \\
\hline & $5, \mathrm{PL}$ & $\mathrm{C}$ & 19.23 & -2.14 & 0.0327 \\
\hline & $5, \mathrm{PR}$ & $\mathrm{C}$ & 18.84 & -2.33 & 0.0202 \\
\hline & $5, \mathrm{~PB}$ & $\mathrm{D}$ & 15.69 & -6.16 & $<0.0001$ \\
\hline & $2.5, \mathrm{PL}$ & $\mathrm{D}$ & 15.10 & 2.14 & 0.03217 \\
\hline & $2.5, \mathrm{PR}$ & $\mathrm{D}$ & 14.80 & 2.33 & 0.0202 \\
\hline & $2.5, \mathrm{~PB}$ & $\mathrm{E}$ & 13.56 & 6.16 & $<0.0001$ \\
\hline & $5, \mathrm{PD}$ & $\mathrm{F}$ & 6.16 & -3.13 & 0.0018 \\
\hline & $2.5, \mathrm{PD}$ & $G$ & 2.52 & 3.13 & 0.0018 \\
\hline
\end{tabular}

The two levels of shoulder angle and shoulder plane resulted in four combinations: $120^{\circ}$ shoulder angle in sagittal plane, $60^{\circ}$ shoulder angle in sagittal plane, $60^{\circ}$ shoulder angle in scapular plane and $120^{\circ}$ shoulder angle in scapular plane. The mean strain indices of these combinations 
are shown in figure 5.2 (a) with 95\% CI. The largest and smallest means were 20.74971 and 13.57037 which are found at the combination of $120^{\circ}$ shoulder angle in sagittal plane and $120^{\circ}$ shoulder angle in scapular plane respectively. The student's t test indicated that the tasks performed in the sagittal plane were more strenuous than in the scapular plane. At $120^{\circ}$ shoulder angle, the increase in the stress between sagittal and scapular plane was much higher than that at $60^{\circ}$ shoulder angle.

The four combinations of shoulder angle and external force were found at $120^{\circ}$ shoulder angle with $5 \mathrm{lb}$ force, $60^{\circ}$ shoulder angle with $5 \mathrm{lb}$ force, $120^{\circ}$ shoulder angle with $2.5 \mathrm{lb}$ force and $60^{\circ}$ shoulder angle with $2.5 \mathrm{lb}$ force. From figure 5.2 (b), it can be clearly said that the combination of $120^{\circ}$ shoulder plane and $5 \mathrm{lb}$ force generates higher shoulder strain and the combination of $2.5 \mathrm{lb}$ force with both $120^{\circ}$ and $60^{\circ}$ shoulder angle generates lower shoulder strain compared to the combinations of $60^{\circ}$ shoulder angle and 5lb external load. The student's t test indicated that the tasks performed using 5lb external load were more strenuous than those tasks performed using $2.5 \mathrm{lb}$ load. At $120^{\circ}$ shoulder angle, the increase in the stress between $2.5 \mathrm{lb}$ and $5 \mathrm{lb}$ external load was much higher than that at $60^{\circ}$ shoulder angle.

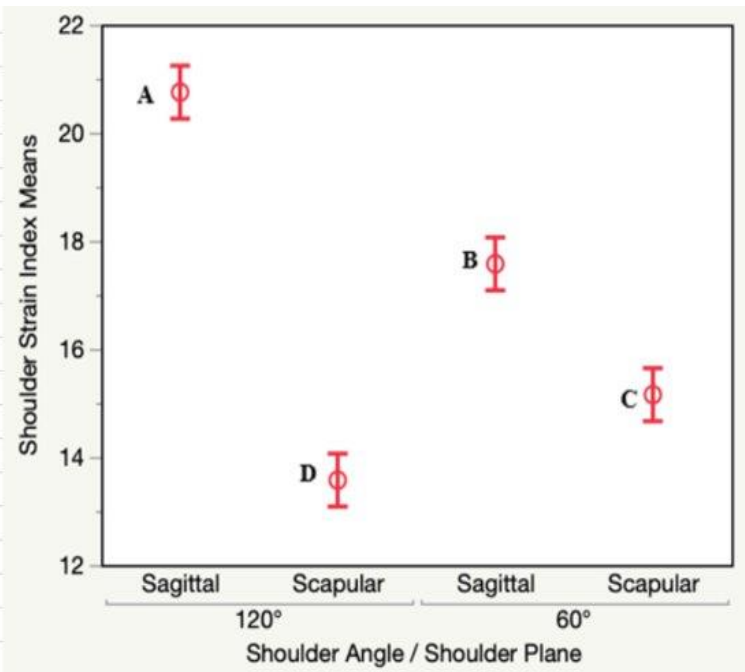

(a)

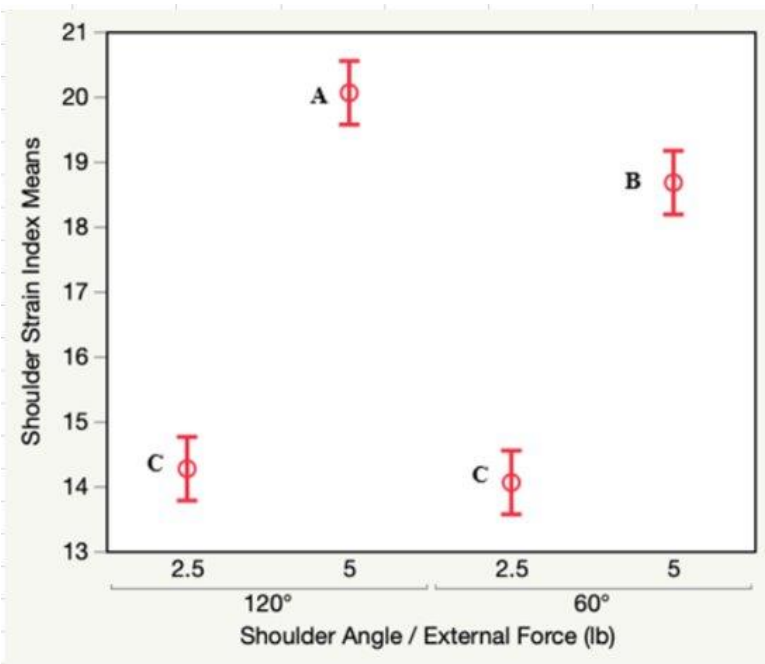

(b)

Figure 5.3 Mean and 95\% CI for all combinations of main factor levels

The two shoulder angles and five exertion directions resulted in a total of ten combinations: $60^{\circ}$ shoulder angle and pulling up, $120^{\circ}$ shoulder angle and pulling up, $120^{\circ}$ shoulder angle and 
pushing right, $60^{\circ}$ shoulder angle and pulling left, $120^{\circ}$ shoulder angle and pulling back, $120^{\circ}$ shoulder angle and pulling left, $60^{\circ}$ shoulder angle and pushing right, $60^{\circ}$ shoulder angle and pulling back, $60^{\circ}$ shoulder angle and pulling down, and $120^{\circ}$ shoulder angle and pulling down. The means and CIs of these combination are shown in figure 5.2 (c). The student's t test informed that pulling up at $60^{\circ}$ shoulder angle produces significantly higher shoulder strain compared to the other combination. Additionally, there is no significant difference between pulling left and pulling back at $60^{\circ}$ shoulder angle as well as pulling left at $120^{\circ}$ shoulder angle. However, the mean strain indices of these three combinations are significantly different from the mean strain indices of other combinations. The student's $t$ test indicated that the tasks performed in pull up direction were more strenuous than those tasks performed in all other directions. At $60^{\circ}$ shoulder angle, the strain index of pull up direction was much higher than that at $120^{\circ}$ shoulder angle.

The two levels of shoulder plane and external force resulted in four combinations: 5lb at sagittal plane, $5 \mathrm{lb}$ at scapular plane, $2.5 \mathrm{lb}$ at sagittal plane and $2.5 \mathrm{lb}$ at scapular plane. From figure 5.2 (d) it can be said that $5 \mathrm{lb}$ external force at sagittal plane and $2.5 \mathrm{lb}$ external force at scapular plane has a higher and lower strain index respectively than other combinations and the student's $t$ test indicates that the difference is significant. Conversely, the mean strain indices of $5 \mathrm{lb}$ at scapular plane and $2.5 \mathrm{lb}$ at sagittal plane are not different from each other but, they vary significantly from other two combinations. The student's $t$ test indicated that the tasks performed using $5 \mathrm{lb}$ external load were more strenuous than those tasks performed using 2.5lb load. At sagittal plane, the increase in the stress between $2.51 \mathrm{~b}$ and $5 \mathrm{lb}$ external load was much higher than that at scapular plane. 


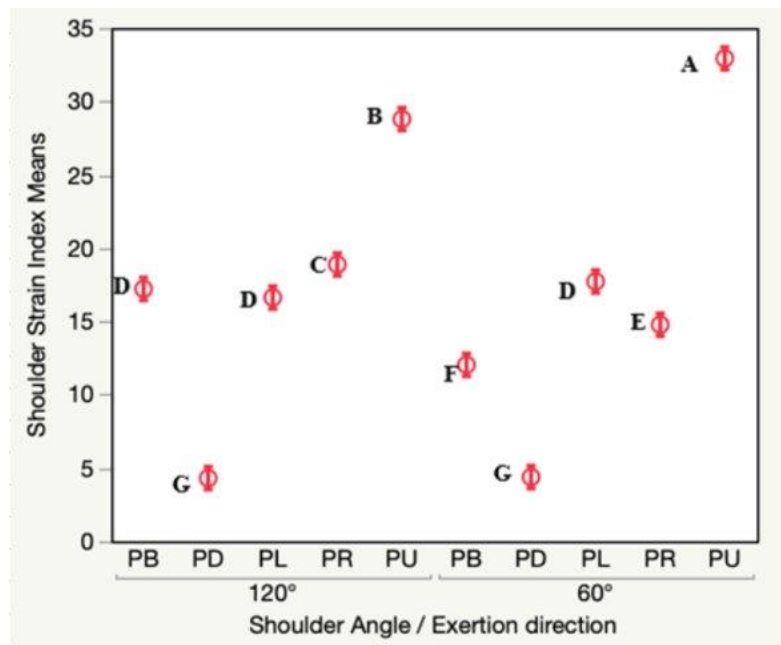

(c)

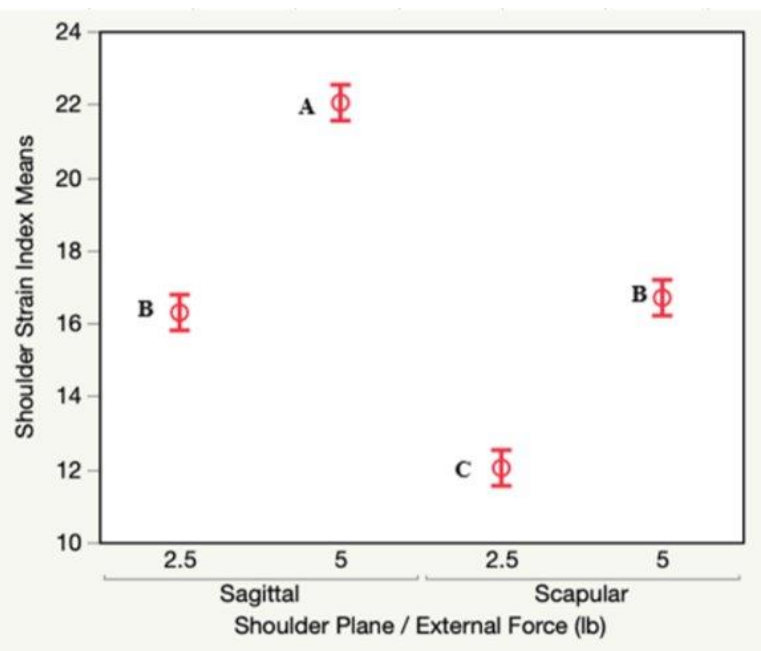

(d)

Figure 5.4 Mean and 95\% CI for all combinations of main factor levels (Continued)

The two shoulder plane and five exertion directions lead to ten combinations: pulling up at sagittal plane, pulling up at scapular plane, pulling left at sagittal plane, pulling right at sagittal plane, pulling back at sagittal plane, pulling right at scapular plane, pulling left at scapular plane, pulling back at scapular plane, pulling down at sagittal plane and pulling down at scapular plane. The mean strain indices of these combinations are shown in figure 5.2 (e). The student's t test reported that pulling up at sagittal plane and pulling down at scapular plane had the higher and lower strain indices compared to the other combinations and the differences were significant. Additionally, it was found that pulling left and right at sagittal plane had no significant difference among themselves but they were different from other combinations. Similarly, pulling left and right at scapular plane as well as pulling left and back at scapular plane were not different from each other but, they were significantly different from other combinations. The student's t test indicated that the tasks performed in pull up direction were more strenuous than those tasks performed in other directions. At sagittal plane, the strain index of pull up direction was much higher than the strain index pull up task at scapular plane.

The combinations of two external force levels at five exertion directions were found at pulling up 5lb, pulling up 2.5lb, pulling left 5lb, pushing right 5lb, pulling back 5lb, pulling left $2.5 \mathrm{lb}$, pulling right $2.5 \mathrm{lb}$, pulling back $2.5 \mathrm{lb}$, pulling down $5 \mathrm{lb}$ and pulling down $2.5 \mathrm{lb}$. These combinations along with their mean strain indices and 95\% CI are shown in figure 5.2 (f). The 
student's $t$ test of these combinations discloses that pulling up 5lb induces significantly higher pain compared to all other combinations whereas pulling down $2.5 \mathrm{lb}$ causes significantly less pain. It also specifies that thought pulling 5lb external load in the left and right directions has no significant difference, they are different from other exertions with force levels and direction. Similarly, pulling $5 \mathrm{lb}$ in the backward direction, pushing $2.5 \mathrm{lb}$ in the right and left directions did not exhibit any significant differences among themselves. The student's $t$ test indicated that the tasks performed using $5 \mathrm{lb}$ external load were more strenuous than those tasks performed using $2.5 \mathrm{lb}$ load. At pull up direction, the strain index of 5lb task was much higher than the strain index of $2.5 \mathrm{lb}$ task.

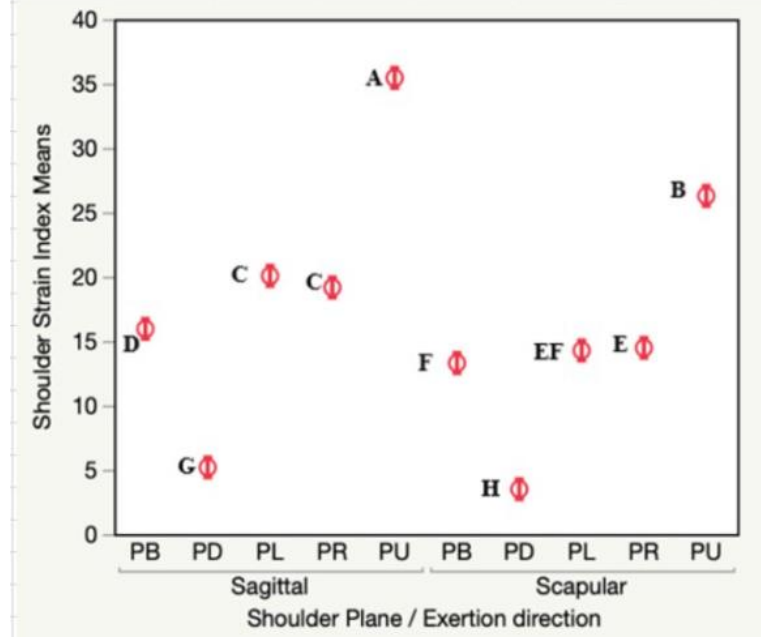

(e)

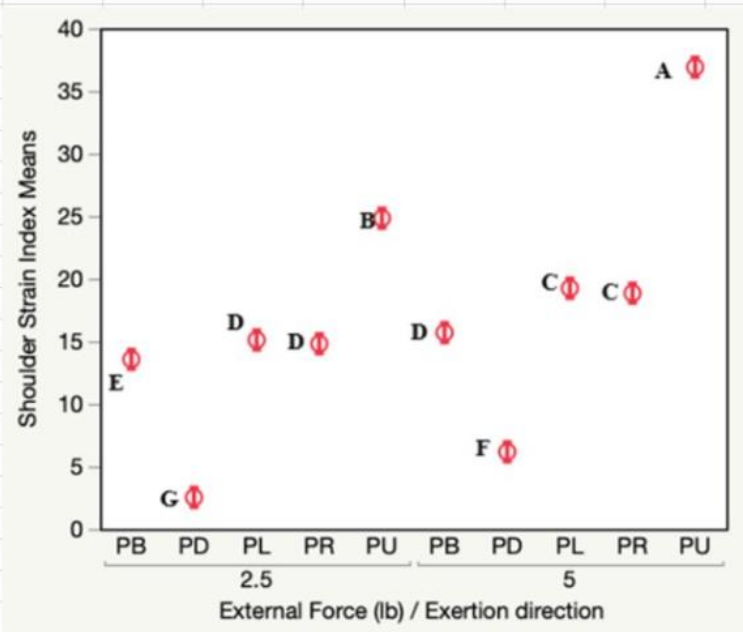

(f)

Figure 5.5 Mean and 95\% CI for all combinations of main factor levels (Continued)

\subsection{Correlation between Muscle Activation and Shoulder Strain Index}

Correlation analysis was conducted to test the relationship between the SI and individual muscle demand as well as the average muscle demand. Table 5.4 shows the correlation between the average shoulder strain indices and seven shoulder muscles: Supraspinatus, Infraspinatus, Middle Deltoid, Anterior Deltoid, Posterior Deltoid, Biceps and Triceps. For the correlation analysis, the Root Mean Square (RMS) values of the individual shoulder muscles EMG data and the average strain indices of 12 participants for the forty arm exertion tasks were calculated. A 
multivariate correlation analysis was performed between the RMS data and the average strain indices.

Table 5.4 Correlation between individual muscles and average strain index

\begin{tabular}{|c|c|c|c|c|c|c|c|}
\hline Correlations & $\begin{array}{c}\text { Supraspi } \\
\text { natus }\end{array}$ & $\begin{array}{c}\text { Infraspin } \\
\text { atus }\end{array}$ & $\begin{array}{c}\text { Middle } \\
\text { deltoid }\end{array}$ & $\begin{array}{c}\text { Anterior } \\
\text { deltoid }\end{array}$ & $\begin{array}{c}\text { Posterior } \\
\text { deltoid }\end{array}$ & Biceps & Triceps \\
\hline $\begin{array}{c}\text { Average } \\
\text { Strain Index }\end{array}$ & 0.546 & 0.760 & 0.556 & 0.672 & 0.399 & 0.637 & 0.116 \\
\hline
\end{tabular}

The correlation values (r) between strain index and the individual muscle activity ranged from 0.116 to 0.760 . Figure 5.3 shows the relationship between the individual shoulder muscle activity and the strain index. The strongest relationship was found for infraspinatus $(r=0.760)$, followed by anterior deltoid ( $\mathrm{r}=0.672)$ and biceps $(\mathrm{r}=0.637)$ (Figure $5.6 \mathrm{~b}, \mathrm{~d}$ and $\mathrm{f}$ ). The middle deltoid ( $\mathrm{r}=0.556)$ and supraspinatus $(\mathrm{r}=0.546)$ also exhibited good relationship (Figure $5.6 \mathrm{c}$ and a). However, moderate and weak correlations were found for posterior deltoid $(\mathrm{r}=0.399)$ and triceps $(\mathrm{r}=0.116)$ (Figure 5.6 e and $\mathrm{g}$ ) 


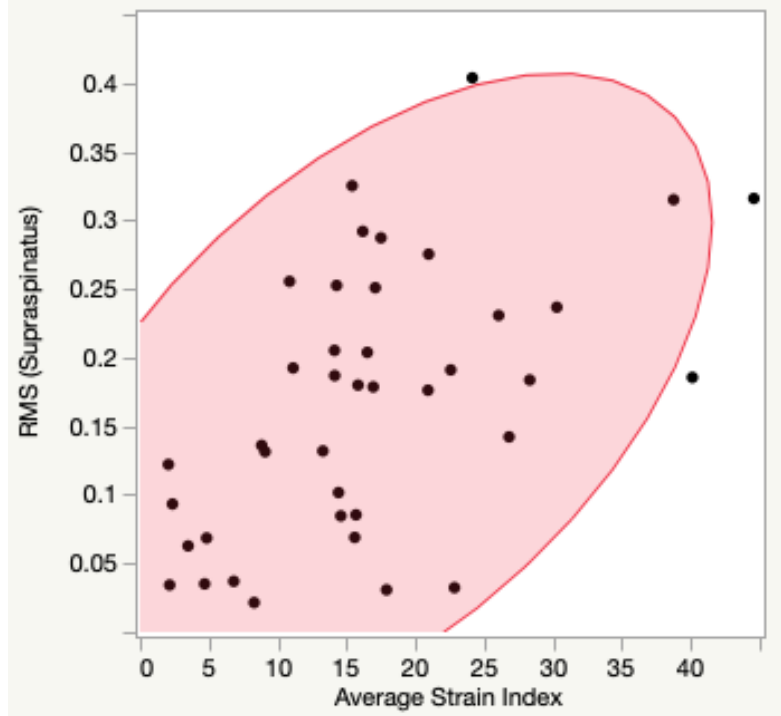

(a)

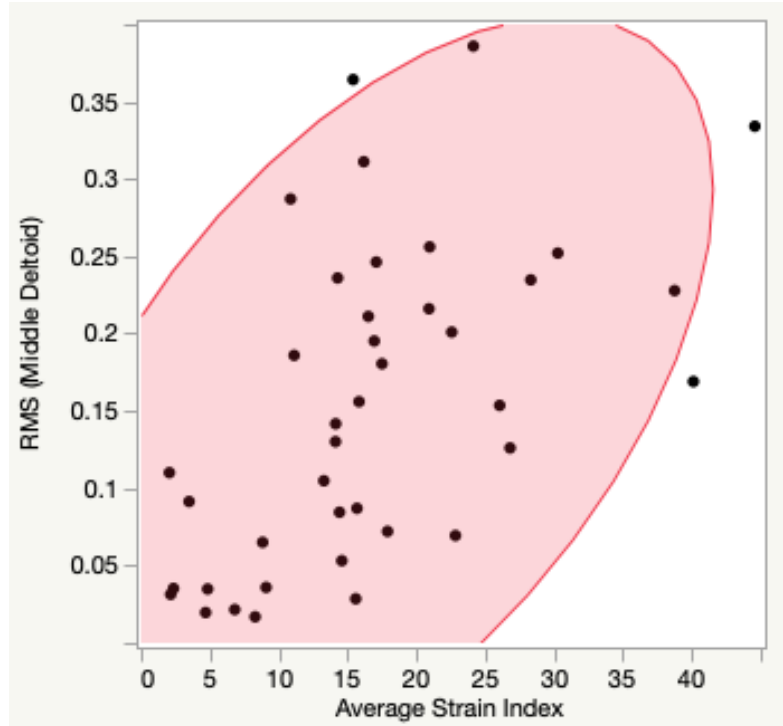

(c)

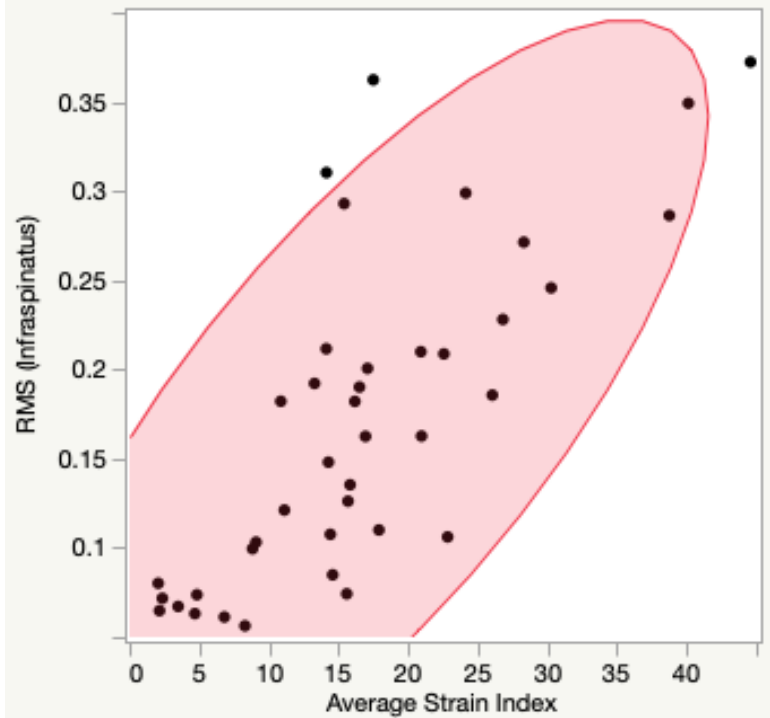

(b)

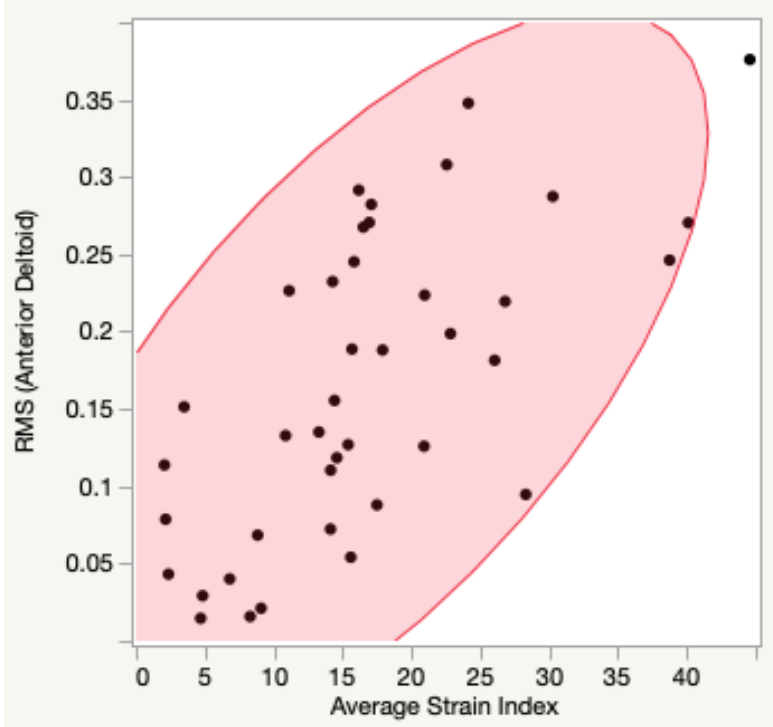

(d) 


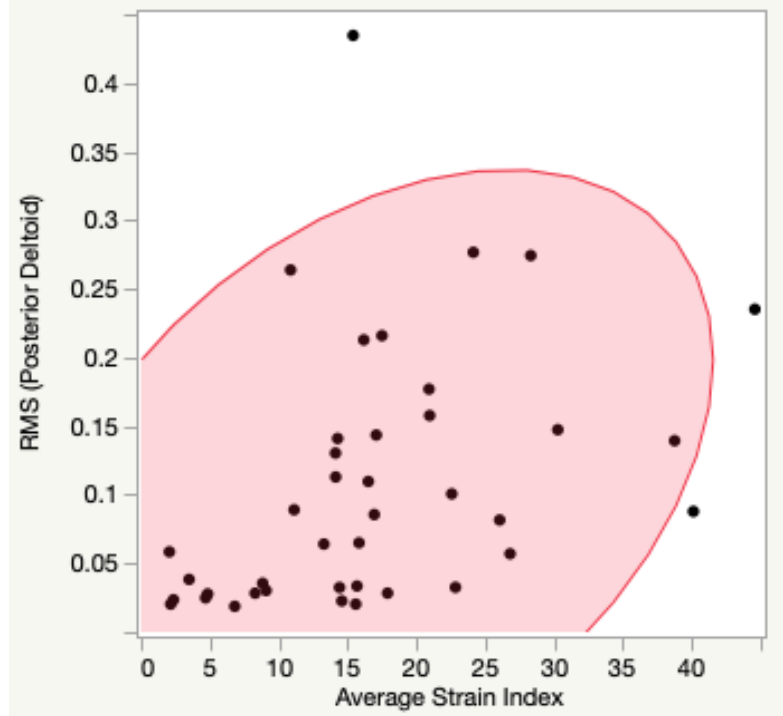

(e)

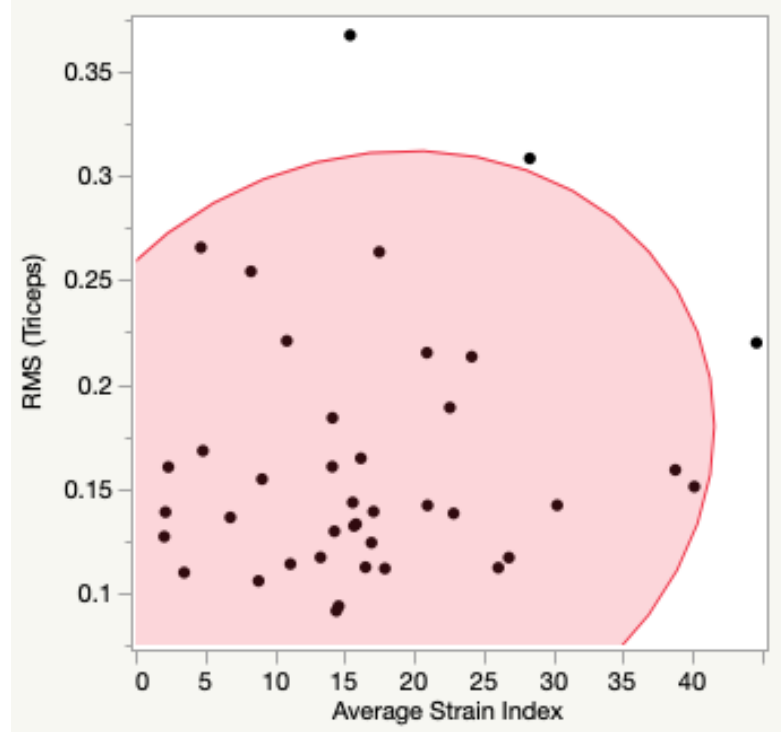

(g)

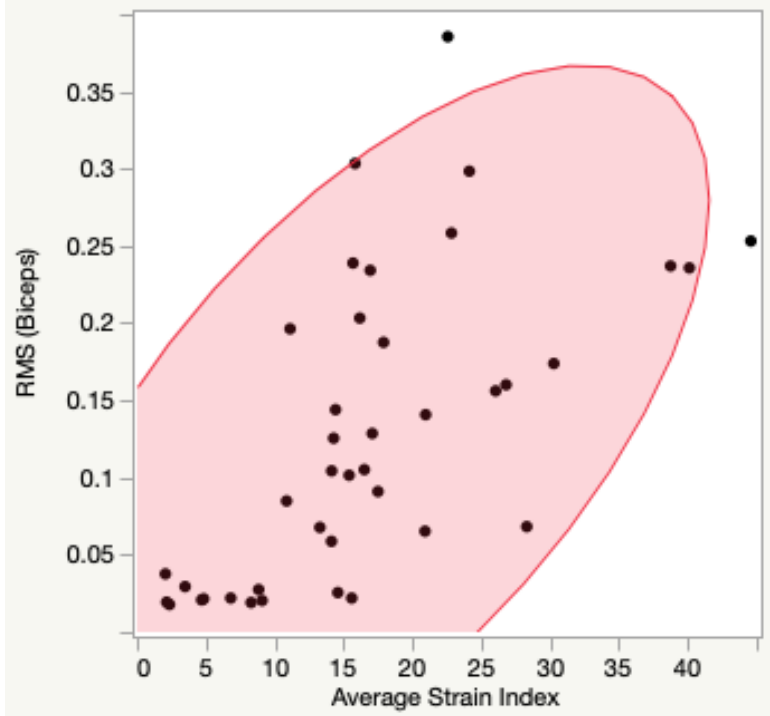

(f)

Figure 5.6 Relationship between individual muscles and average strain index

For assessing the relationship between the overall shoulder demand and strain index, a separate correlation analysis was performed. The test reported a correlation value of 0.6944 which indicates a strong relationship (Figure 5.4). 


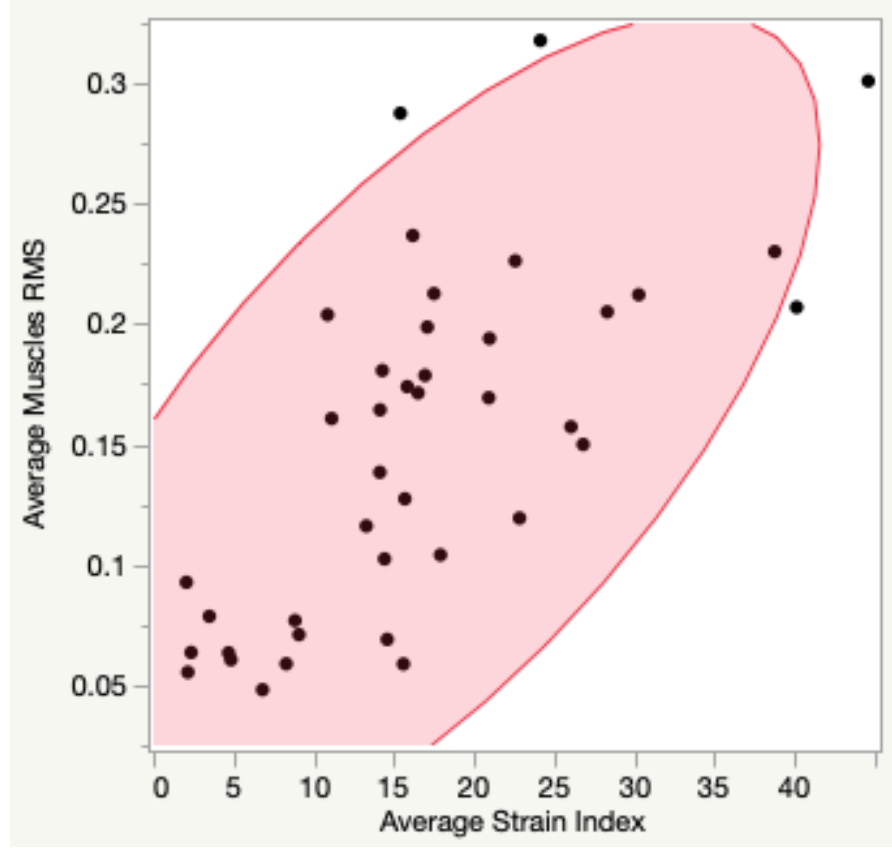

Figure 5.7 Relationship between average muscle activation and strain index 


\section{Chapter 6: Discussion and Conclusion}

In industrial and occupational settings, workers are often required to perform forceful arm exertions. Almost all forceful arm exertions involve active contribution by the shoulder joint. The main shoulder joint, glenohumeral joint, is the most versatile joint with range of motion covering almost $65 \%$ of a sphere. Humans can perform forceful arm exertions of various magnitudes, in any possible direction using postures that can be encompassed within $65 \%$ of sphere using the shoulder joint. The flexibility provided by the shoulder joint makes it one of the most functional joints in the human body. The functionality makes the shoulder joint also venerable to a range of workrelated risk factors. In the literature, shoulder joint has been characterized as a joint with infinite functional degrees of freedom making it one the most challenging joint to study from risk assessment point of view. Although multiple studies have evaluated the load-response relationship for the shoulder joint due to the exposure to different work-related factors, there is scarcity of risk assessment tools. Very recently Chowdhury et al. (2016) developed a strain index to quantify the strain imposed on the main shoulder joint (glenohumeral joint) during forceful arm exertions. The strain index ranges between 0 and 100 and is derived based on the concept of concavity compression mechanism. For any forceful arm exertion, strain index can be computed provided the direction and magnitude of internal joint reaction forces acting at the glenohumeral joint are known. Upon development of the strain index, Chowdhury et al. (2016) performed some basic validation studies using simplistic static and dynamic exertions. A detailed and more comprehensive validation of the strain index is still lacking. It is critical that strain index is validated using a range of physical exertions to substantiate it as an appropriate risk assessment tool. In this study 40 forceful arm exertions were used to assess (1) sensitivity of the strain index to work-related factors (such as shoulder angle, shoulder plane, external force level and exertion direction); (2) the relationship of model-based strain index with physiological muscle activity data.

The strain index was found to be quite sensitive to the various work-related factors. Statistical significance was observed for the effect of shoulder plane, shoulder angle, external force and exertion direction on strain index. The mean strain index values ranged from 0.76 to 44.77 (Figure 6.1). Within the observed range, higher strain index values (25 to 44) were observed for the exertions performed in the pull up and right directions in sagittal and scapular planes, at $60^{\circ}$ 
and $120^{\circ}$ shoulder angles using 2.5 and 5lb external loads. Moderate strain index values (15 to 25) were observed for the exertions performed in the pull back, left, right and up directions in sagittal and scapular planes, at $60^{\circ}$ and $120^{\circ}$ shoulder angles using 2.5 and $51 \mathrm{~b}$ external loads. The strain index values remained quite low (0.77 to 15$)$ for the exertions performed in the pull back, down left and right directions in sagittal and scapular planes, at $60^{\circ}$ and $120^{\circ}$ shoulder angles using 2.5 and $51 b$ external loads.

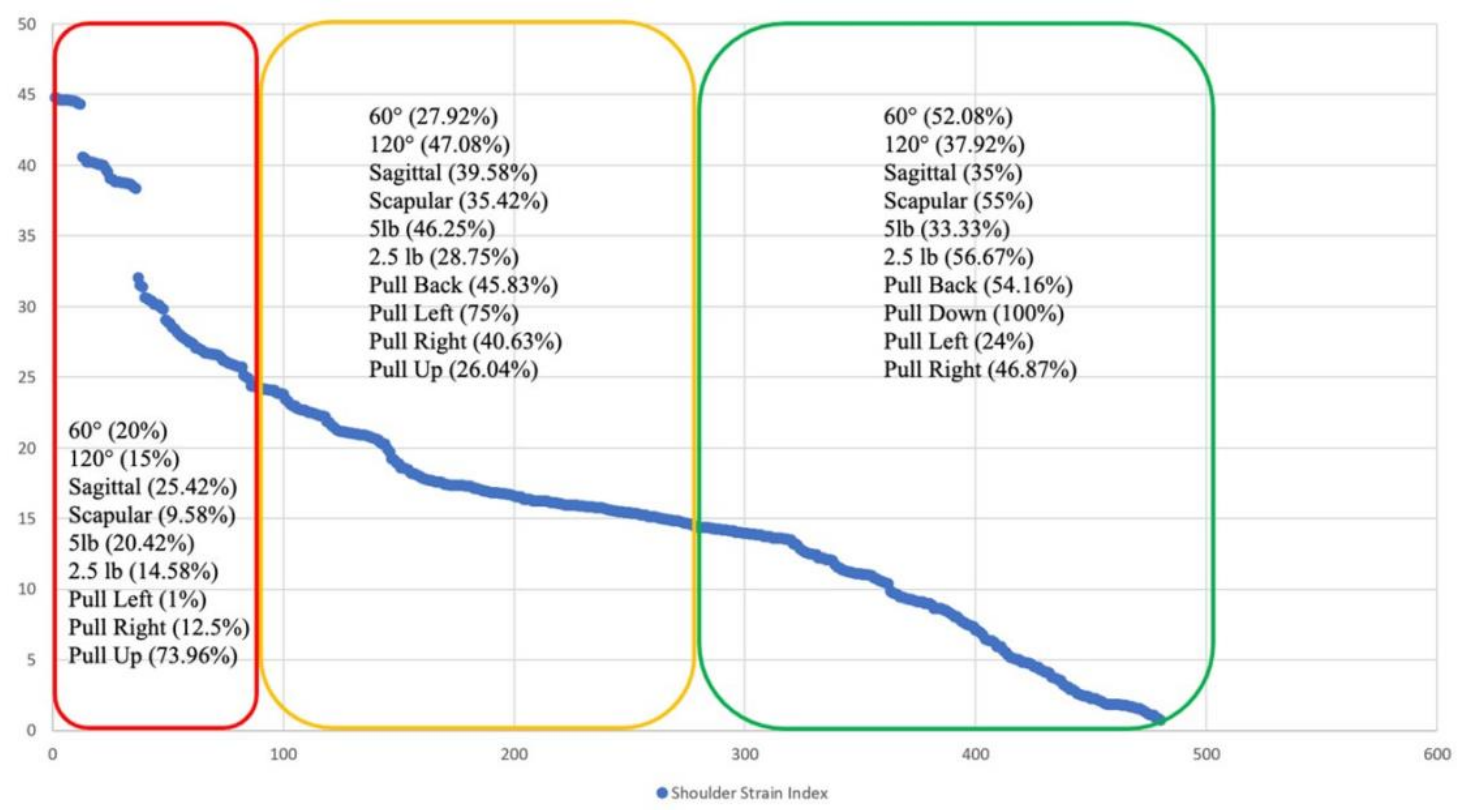

Figure 6.1 Shoulder strain index values observed in this study

Higher strain was observed with an increase in the magnitude of the force. This was quite expected and consistent with previous studies. Antony et al., (2010) observed shoulder exertions with three hand load conditions (no load, $0.5 \mathrm{~kg}$ and $30 \%$ grip) in three shoulder planes and four elevation angles. They found that an addition of $0.5 \mathrm{~kg}$ hand load increased the shoulder muscle activity by $4 \%$ of MVC. For automotive assembly operations performed at different combinations of workpiece weights (3lb and 6lb) and hand-tool weights (1lb, 2lb and 4lb), shoulder postures and duration, Garg et al., (2006) found that ratings of perceived exertion, fatigue and pain increased with an increase in the weight of workpiece and hand-tool. Piscione et al., (2006) reported the 
effect of backpack carrying load $(0 \mathrm{~kg}, 10 \mathrm{~kg}$ and $20 \mathrm{~kg}$ ) on fatigue of middle deltoid and upper trapezius muscles. A significant increase in fatigability was observed in both muscles with increasing the mass of load, which was similar to the observations of the present study. However, the increase in the strain index values with an increase in the magnitude of force was small. This is mainly attributed to the small force levels $(2.5 \mathrm{lb}$ and $5 \mathrm{lb})$ used in this study. These force levels are very small in comparison with the maximum controllable force by humans which ranges from 15.5 Newtons (3.49 lb) to 102.3 Newtons (23lb) (Tan et al., 1994).

Higher strain index was observed at $120^{\circ}$ shoulder angle compared to $60^{\circ}$ shoulder angle, which is consistent with previous studies (Antony et al., 2010; Sigholm et al., 1983; Järvholm et al., 1991). Brookham et al., (2010) investigated the impact of shoulder joint flexion $\left(0^{\circ}, 60^{\circ}, 70^{\circ}\right.$, $80^{\circ}, 90^{\circ}$ ) and humeral rotation on shoulder muscle activation while exerting a light tool, and reported a positive relationship between shoulder flexion angle and shoulder muscle activity. Straker et al., (1997) investigated the effect of posture on workers' performance. The study was conducted at two shoulder joint flexion angles $\left(0^{\circ}\right.$ and $\left.30^{\circ}\right)$ and two noise levels. Their findings suggested that shoulder joint flexed at $30^{\circ}$ was associated with poor performance, high discomfort ratings, and higher fatigue compared to shoulder joint flexed at $0^{\circ}$. Overall, the current and the previous studies seem to indicate that shoulder strain increases with an increase in the shoulder angle.

A comparison between shoulder planes demonstrated tha the strain index in the sagittal plane was significantly higher than in the scapular plane. Multiple previous studies haves reported similar trends (Antony and Keir, 2010; Kai et al., 2012; Minning et al., 2007). Kai et al., (2012) compared the amount of fatigue on infraspinatus muscle during resisted arm elevation and reported that arm elevation in the sagittal plane resulted in higher amount of fatigue than scapular plan. In a study that analyzed the activation of scapular stabilizing muscles during isometric tasks, Oliveira et al., (2013) stated that the ratios between upper trapezius/lower trapezius and upper trapezius/serratus anterior were higher in the frontal plane compared to the scapular plane. Thus, the findings suggest that the shoulder strain is higher in sagittal plane than scapular plane.

When comparing the direction of force exertions, the strain index values were the highest in pull up direction, followed by pull left, pull right, pull back and pull down directions. Similar results were found in the study conducted by Alasim et al., (2019). In their study, the authors 
observed the effects of pulling and pushing exertions in five directions (pull right, pull left, pull back, pull down and pull up) using three force levels. They found that exertions performed in up and right directions generated higher muscle activation and higher ratings of perceived exertion than the exertions performed in other directions. On the other hand, while observing the effects of multiple work locations and six directions (forward, backward, upward, downward, left and right) of force application $(40 \mathrm{~N})$ on shoulder muscular activity, Cudlip et al., (2016) reported that backward exertions generated the highest mean overall muscle activity. Similar results were found in a study by Chopp et al., (2010) where they estimated the muscle load at two work configurations, four different angles with vertical axis, and five directions (backwards, forwards, downwards, sideways and upwards). They concluded that pulling in backwards direction generated the greater muscular demand than all other force directions. These observations contradicted with the findings of the present study as in this study the highest strain index values were found in the pull up direction. The differences in the study findings could be attributed to the experimental design related factors. For example, the external forces used in the current study were lower than some of the previous studies. This lower level of force might not have any significant effect on pull back directions. The findings related to the exertions performed in left, right and down directions are consistent with a study performed by McDonald et al., (2014). Pull down tasks in this study generated the least strain index values. Similar results were found in the studies conducted by Haslegrave et al., (1997) and Cudlip et al., (2016). These studies suggested that due to the assistance of gravitational force, pull down tasks were easier than the tasks in the other directions.

The correlation analysis drew a clear picture of the relationship between the model-based strain index and physiological loading of the shoulder joint. Previous studies have used correlation analysis to establish relationship between model driven data and physiological data. One such analysis was found in the study of Dickerson et al., (2006) where the external dynamic shoulder torque was calculated using an upper extremity biomechanical model and perceived shoulder muscular effort was rated by individual subject. The correlation analysis between these factors demonstrated that individual subject torque values were positively correlated with perceived effort scores $\left(r^{2}=0.45-0.77\right)$. Laursen at al., (1998) applied correlation analysis for validating an EMG based model used to estimate muscle forces at glenohumeral joint. They concluded that the correlation values between the shoulder joint moment and external force moment were highest at abduction/adduction moment (0.65 to 0.95$)$ and flexion/extension moment (0.7 to 0.9$)$. 
Additionally, several studies have implemented correlation analysis for assessing the relationship between physiological data of muscle activation and output of biomechanical model (Dickersin et al., 2008; Hawkes et al., 2012; Alasim et al., 2019). Generally, correlation values within the range of 0 to 0.3 indicates weak positive correlation, 0.3 to 0.7 indicates moderate positive correlation, and 0.7 to 1.0 indicates strong positive correlation (Ratner, 2009). From the correlation analysis of this study, it was found that the shoulder strain index demonstrated a strong positive correlation with infraspinatus (0.760), while showed moderate correlations with anterior deltoid (0.672), biceps (0.637), middle deltoid (0.556) and supraspinatus (0.546). This result suggests that one rotator cuff muscle (infraspinatus) shows high relation and other (supraspinatus) shows moderate relation with the strain index values. The non-rotator cuff muscles exhibit moderate to low values of correlation. The result is consistent with the trend of higher activation values of rotator cuff muscles than other shoulder muscles during forceful arm exertions. Previous studies have suggested that the infraspinatus muscles show a high activation level during manual handling tasks (Goubault et al., 2021). In a study conducted by Alasim et al., (2019) it was found that rotator cuff muscles (infraspinatus and supraspinatus) and middle deltoid muscles showed higher activation than all other muscles during strenuous tasks. Sigholm et al., (1984) and Sporrong et al., (1996) also reported higher activation of infraspinatus and supraspinatus muscle during pull up and pull right exertions. The reason for higher activation level of rotator cuff muscles is that the forces produced by these muscles significantly contribute to the concavity compression process of glenohumeral joint stabilization (Wuelker et al., 1998).

Though in our study a strong correlation value was observed for the infraspinatus muscle, the supraspinatus muscle showed a moderate relationship with the strain index values. Additionally, the anterior deltoid muscles generated a better correlation value than supraspinatus muscles. This type of different muscle activation patterns were also found in the several studies. Cudlip et al., (2016) found that in overhead exertions anterior deltoid muscle had higher muscle activity (activity level >50\%MVE) than supraspinatus muscle (activity level>45\% MVE). Chopp et al., (2010) found that anterior deltoid muscles showed higher activation level compared to infraspinatus muscles at different combinations of work configuration, target angle and force direction. This different pattern of muscle activations could be explained by the fact that different configuration and combination of work-related factors had different effects on the activation level of shoulder muscles, thus they exhibited different pattern from general trend. 
The lowest correlation value was observed between strain index values and triceps muscle (0.116). Similar pattern of muscle activation of triceps was observed in Alasim et al., (2016) study. The low activation of triceps muscles indicate that these muscles do not actively participate in concavity compression process of shoulder joint.

A high correlation coefficient of almost 0.7 was observed when activities of shoulder muscles were averaged and correlated with the strain index, further suggesting that shoulder strain index developed by Chowdhury et al. (2016) shows a strong relationship with the overall physiological demand of the shoulder joint. Such strong relationship validates the strain index as an appropriate tool to assess the risk of injury to the shoulder joint due to static work-related forceful arm exertions.

\subsection{Study Limitations and Direction for Future Studies}

In this validation study, only static exertions were used. Workplace exertions are static as well as dynamic. In order to fully validate the strain index, future study can evaluate dynamic exertions. The force values used in this study were low (2.5 and $5 \mathrm{lbs}$.) considering the much higher force exertion ability of the shoulder joint. The low force values limited the strain index in a rather narrow range of $<44$, future studies can look at higher force values to test and validate shoulder strain index in higher ranges $(50-75,75$ to 100 , etc.). However, there is risk of creating higher strain and/or injury during the exertions with high strain index (especially $>75$ ) and therefore it will be challenging to design such studies. The effect of age of the participants was not considered in this validation study. In workplace settings there are workers from various age groups. Additionally, the total number of participants hired in this study was only 12 . Future studies can include more participants from multiple age groups and consider the effect of age on strain index values. However, most of the existing biomechanical modelling systems including AnyBody do not have options to incorporate age as a factor in the biomechanical models. In this study, a preexisting shoulder model from the repository of the AnyBody modelling system was used. All models are subjected to some levels of assumptions, future studies can consider other shoulder models (such as Open Sim) to further validate the strain index. In this study the models were scaled using basic participant data such as gender, height, and weight. There are newer modelling options 
for creating more accurate participant specific models by incorporating more precise arm anthropometric measurement. Future studies can explore such participant-specific modelling approaches. The validation was performed using dominant (right) hand, future studies can focus on non-dominant hand.

\subsection{Final Conclusion}

The study results indicate that the shoulder strain index developed by Chowdhury et al. (2016) is sensitive to the work-related factors that are typical during occupational forceful arm exertions. The study results also indicate that the shoulder strain index exhibits a strong relationship with the real physiological data. Thus, based on the findings of this study, it can be concluded that the shoulder strain index can be used as a risk assessment tool to accurately compare and predict the risk of shoulder WMSDs during work related static forceful arm exertions. 


\section{References}

Alasim, H. N., Nimbarte, A. D., \& Jaridi, M. (2019). Impact of pulling direction and magnitude of force exertion on the activation of shoulder muscles. International Journal of Industrial Ergonomics, 69, 14-22.

Andreas, G. W. J., \& Johanssons, E. (2018). Observational methods for assessing ergonomic risks for workrelated musculoskeletal disorders. A scoping review. Revista Ciencias de la Salud, 16(SPE), 8-38

Antony, N. T., \& Keir, P. J. (2010). Effects of posture, movement and hand load on shoulder muscle activity. Journal of Electromyography and Kinesiology, 20(2), 191-198.

Artemiadis, P. (2012). EMG-based robot control interfaces: past, present and future. Advances in Robotics \& Automation, 1(2), 1-3.

Bassani, T., Stucovitz, E., Qian, Z., Briguglio, M., \& Galbusera, F. (2017). Validation of the AnyBody full body musculoskeletal model in computing lumbar spine loads at L4L5 level. Journal of biomechanics, 58, 89-96.

Beese, N. O., Rodriguez, F. S., Spilski, J., \& Lachmann, T. (2021). Development of a Digital Video-Based Occupational Risk Assessment Method. Frontiers in Public Health, 9, 720.

Bodin, J., Garlantézec, R., Costet, N., Descatha, A., Viel, J. F., \& Roquelaure, Y. (2020). Shoulder pain among male industrial workers: Validation of a conceptual model in two independent French working populations. Applied Ergonomics, 85, 103075.

Braman, J. P., Zhao, K. D., Lawrence, R. L., Harrison, A. K., \& Ludewig, P. M. (2014). Shoulder impingement revisited: evolution of diagnostic understanding in orthopedic surgery and physical therapy. Medical \& biological engineering \& computing, 52(3), 211-219.

Brookham, R. L., Wong, J. M., \& Dickerson, C. R. (2010). Upper limb posture and submaximal hand tasks influence shoulder muscle activity. International journal of industrial ergonomics, 40(3), 337-344.

Charles, L. E., Ma, C. C., Burchfiel, C. M., \& Dong, R. G. (2018). Vibration and ergonomic exposures associated with musculoskeletal disorders of the shoulder and neck. Safety and health at work, 9(2), 125132.

Chopp, J. N., Fischer, S. L., \& Dickerson, C. R. (2010). The impact of work configuration, target angle and hand force direction on upper extremity muscle activity during sub-maximal overhead work. Ergonomics, 53(1), 83-91.

Chowdhury, S. K., Nimbarte, A. D., Hsiao, H., Gopalakrishnan, B., \& Jaridi, M. (2018). A biomechanical shoulder strain index based on stabilizing demand of shoulder joint. Ergonomics, 61(12), 1657-1670.

Chu, P. C., Wang, T. G., \& Guo, Y. L. (2021). Work-related and personal factors in shoulder disorders among electronics workers: findings from an electronics enterprise in Taiwan. BMC public health, 21(1), $1-15$.

Cudlip, A. C., Meszaros, K. A., \& Dickerson, C. R. (2016). The influence of hand location and force direction on shoulder muscular activity in females during nonsagittal multidirectional overhead exertions. Human factors, 58(1), 120-139. 
Curtis, K. A., Roach, K. E., Applegate, E. B., Amar, T., Benbow, C. S., Genecco, T. D., \& Gualano, J. (1995). Development of the wheelchair user's shoulder pain index (WUSPI). Spinal Cord, 33(5), 290-293.

Damsgaard, M., Rasmussen, J., Christensen, S. T., Surma, E., \& De Zee, M. (2006). Analysis of musculoskeletal systems in the AnyBody Modeling System. Simulation Modelling Practice and Theory, 14(8), 1100-1111.

da Silva, I. H., da Silva Junior, J. M., Santos-de-Araújo, A. D., de Paula Gomes, C. A. F., da Silva Souza, C., de Souza, P. H. V. A., \& Dibai-Filho, A. V. (2018). Intra-and inter-reliability of fleximetry in individuals with chronic shoulder pain. Physical Therapy in Sport, 32, 115-120.

Dickerson, C. R., Martin, B. J., \& Chaffin, D. B. (2006). The relationship between shoulder torques and the perception of muscular effort in loaded reaches. Ergonomics, 49(11), 1036-1051.

Dickerson, C. R., Hughes, R. E., \& Chaffin, D. B. (2008). Experimental evaluation of a computational shoulder musculoskeletal model. Clinical Biomechanics, 23(7), 886-894.

Do, T. V., Dario, P., Son, T. M., \& Mazzoleni, S. (2019, July). An Approach of Shoulder Movement Analysis Using OpenSim Software. In 2019 International Conference on System Science and Engineering (ICSSE) (pp. 511-516). IEEE.

Feyen, R., Liu, Y., Chaffin, D., Jimmerson, G., \& Joseph, B. (2000). Computer-aided ergonomics: a case study of incorporating ergonomics analyses into workplace design. Applied ergonomics, 31(3), 291-300.

Forsman, M., Stridqvist, J., \& Persson, O. (2006). A checklist extension of VIDAR-a participative videobased method for ergonomic evaluation. IEA2006.

Garg, A., Hegmann, K., \& Kapellusch, J. (2006). Short-cycle overhead work and shoulder girdle muscle fatigue. International Journal of Industrial Ergonomics, 36(6), 581-597.

Goubault, E., Martinez, R., Bouffard, J., Dowling-Medley, J., Begon, M., \& Dal Maso, F. (2021). Shoulder electromyography-based indicators to assess manifestation of muscle fatigue during laboratory-simulated manual handling task. Ergonomics, (just-accepted), 1-50.

Grauhan, N. F., Niehues, S. M., Gaudin, R. A., Keller, S., Vahldiek, J. L., Adams, L. C., \& Bressem, K. K. (2021). Deep learning for accurately recognizing common causes of shoulder pain on radiographs. Skeletal Radiology, 1-8.

Hatze, H. (1974). The meaning of the term" biomechanics". Journal of biomechanics, 7(2), 189-190.

Haslegrave, C. M., Tracy, M. F., \& Corlett, E. N. (1997). Force exertion in awkward working posturesstrength capability while twisting or working overhead. Ergonomics, 40(12), 1335-1356.

Heberger, J. R., Nasarwanji, M. F., Paquet, V., Pollard, J. P., \& Dempsey, P. G. (2012, September). Interrater reliability of video-based ergonomic job analysis for maintenance work in mineral processing and coal preparation plants. In Proceedings of the Human Factors and Ergonomics Society Annual Meeting (Vol. 56, No. 1, pp. 2368-2372). Sage CA: Los Angeles, CA: SAGE Publications.

Hernandez, Y., Han Kim, K., Benson, E., Jarvis, S., \& Rajulu, S. (2019, November). Video-based ergonomic assessment for spacesuit training in a microgravity analog. In Proceedings of the Human Factors 
and Ergonomics Society Annual Meeting (Vol. 63, No. 1, pp. 987-991). Sage CA: Los Angeles, CA: SAGE Publications.

Hignett, S., \& McAtamney, L. (2000). Rapid entire body assessment (REBA). Applied ergonomics, 31(2), 201-205.

Högfors, C., Peterson, B., Sigholm, G., \& Herberts, P. (1991). Biomechanical model of the human shoulder joint-II. The shoulder rhythm. Journal of biomechanics, 24(8), 699-709.

Järvholm, U., Palmerud, G., Karlsson, D., Herberts, P., \& Kadefors, R. (1991). Intramuscular pressure and electromyography in four shoulder muscles. Journal of Orthopaedic Research, 9(4), 609-619.

Ji, Z., Wang, H., Jiang, G., \& Li, L. (2016). Analysis of muscle activity utilizing bench presses in the AnyBody simulation modelling system. Modelling and Simulation in Engineering, 2016.

Jiskani, I. M., Silva, J. M. N. D., Chalgri, S. R., Behrani, P., Lu, X., \& Manda, E. (2020). Mine health and safety: influence of psychosocial factors on musculoskeletal disorders among miners in Pakistan. International Journal of Mining and Mineral Engineering, 11(2), 152-167.

Kai, Y., Gotoh, M., Nagata, K., \& Shiba, N. (2012). Infraspinatus fatigue during resisted arm elevation with isometric contraction: an electromyographic study. Journal of shoulder and elbow surgery, 21(8), 11041109.

Kee, D. (2021). Comparison of OWAS, RULA and REBA for assessing potential work-related musculoskeletal disorders. International Journal of Industrial Ergonomics, 83, 103140.

Kramer, A. F. (2020). Physiological metrics of mental workload: A review of recent progress. Multipletask performance, 279-328.

Laursen, B., Jensen, B. R., Németh, G., \& Sjøgaard, G. (1998). A model predicting individual shoulder muscle forces based on relationship between electromyographic and 3D external forces in static position. Journal of biomechanics, 31(8), 731-739.

Lazarus, M. D., Sidles, J. A., DOUGLAS T HARRYMAN, I. I., \& MATSEN III, F. A. (1996). Effect of a chondral-labral defect on glenoid concavity and glenohumeral stability. A cadaveric model. JBJS, 78(1), 94-102.

Lenarčič, J., \& Klopčar, N. (2006). Positional kinematics of humanoid arms. Robotica, 24(1), 105-112.

Lim, K. H., Hill, G., Tarr, G., \& van Rij, A. (2013). Deep venous reflux definitions and associated clinical and physiological significance. Journal of Vascular Surgery: Venous and Lymphatic Disorders, 1(4), 325332

Linaker, C. H., \& Walker-Bone, K. (2015). Shoulder disorders and occupation. Best practice \& research Clinical rheumatology, 29(3), 405-423.

Liu, J., Ren, Y., Xu, D., Kang, S. H., \& Zhang, L. Q. (2019). EMG-based real-time linear-nonlinear cascade regression decoding of shoulder, elbow, and wrist movements in able-bodied persons and stroke survivors. IEEE Transactions on Biomedical Engineering, 67(5), 1272-1281. 
Lu, T. W., \& Chang, C. F. (2012). Biomechanics of human movement and its clinical applications. The Kaohsiung journal of medical sciences, 28(2), S13-S25.

Mansouri, M., \& Reinbolt, J. A. (2012). A platform for dynamic simulation and control of movement based on OpenSim and MATLAB. Journal of biomechanics, 45(8), 1517-1521.

Matebu, A., \& Dagnew, B. (2014). Design of manual material handling system through computer aided ergonomics: a case study at BDTSC textile firm. International Journal for Quality Research, 8(4), 557568.

McDonald, A. C., Brenneman, E. C., Cudlip, A. C., \& Dickerson, C. R. (2014). The spatial dependency of shoulder muscle demands for seated lateral hand force exertions. Journal of applied biomechanics, 30(1), $1-11$.

McKinnon, C. D., Sonne, M. W., \& Keir, P. J. (2019, November). Comparison of video-based and traditional physical demands description methods. In Proceedings of the Human Factors and Ergonomics Society Annual Meeting (Vol. 63, No. 1, pp. 1169-1172). Sage CA: Los Angeles, CA: SAGE Publications.

Mehrdad, R., Dennerlein, J. T., Haghighat, M., \& Aminian, O. (2010). Association between psychosocial factors and musculoskeletal symptoms among Iranian nurses. American journal of industrial medicine, 53(10), 1032-1039.

Merryweather, A. S., Loertscher, M. C., \& Bloswick, D. S. (2009). A revised back compressive force estimation model for ergonomic evaluation of lifting tasks. Work, 34(3), 263-272.

Minning, Stephen, Colin A. Eliot, Tim L. Uhl, and Terry R. Malone. "EMG analysis of shoulder muscle fatigue during resisted isometric shoulder elevation." Journal of Electromyography and Kinesiology 17, no. 2 (2007): 153-159.

Minoughan, C. E., Schumaier, A. P., Fritch, J. L., \& Grawe, B. M. (2018). Correlation of Patient-Reported Outcome Measurement Information System physical function upper extremity computer adaptive testing, with the American Shoulder and Elbow Surgeons Shoulder assessment form and Simple Shoulder Test in patients with shoulder pain. Arthroscopy: The Journal of Arthroscopic \& Related Surgery, 34(5), 14301436.

Mulla, D. M., Hodder, J. N., Maly, M. R., Lyons, J. L., \& Keir, P. J. (2020). Glenohumeral stabilizing roles of the scapulohumeral muscles: Implications of muscle geometry. Journal of biomechanics, 100, 109589

Nicolozakes, C. (2021). Quantifying the Biomechanical and Neural Factors Contributing to Translational Shoulder Stability (Doctoral dissertation, Northwestern University).

Nimbarte, A. D., Aghazadeh, F., Ikuma, L. H., \& Harvey, C. M. (2010). Neck disorders among construction workers: understanding the physical loads on the cervical spine during static lifting tasks. Industrial health, $48(2), 145-153$.

Odle, B., Forrest, G., Reinbolt, J., \& Dyson-Hudson, T. (2011, January). Development of an OpenSim shoulder model for manual wheelchair users with tetraplegia. In ASME International Mechanical Engineering Congress and Exposition (Vol. 54884, pp. 541-542). 
Oliveira, V. M. A. D., Batista, L. D. S. P., Pirauá, A. L. T., Pitangui, A. C. R., \& Araújo, R. C. D. (2013). Electromyographic activity and scapular dyskenesia in athletes with and without shoulder impingement syndrome. Revista Brasileira de Cineantropometria \& Desempenho Humano, 15, 193-203.

O'Sullivan, C., Persson, U. M., Blake, C., \& Stokes, M. (2012). Rehabilitative ultrasound measurement of trapezius muscle contractile states in people with mild shoulder pain. Manual therapy, 17(2), 139-144.

Palmerud, G., Forsman, M., Sporrong, H., Herberts, P., \& Kadefors, R. (2000). Intramuscular pressure of the infra-and supraspinatus muscles in relation to hand load and arm posture. European Journal of Applied Physiology, 83(2-3), 223-230

Panariello, D., Grazioso, S., Caporaso, T., Palomba, A., Di Gironimo, G., \& Lanzotti, A. (2019, June). Evaluation of human joint angles in industrial tasks using OpenSim. In 2019 II Workshop on Metrology for Industry 4.0 and IoT (MetroInd4. O\&IoT) (pp. 78-83). IEEE.

Pehkonen, I., Ketola, R., Ranta, R., \& Takala, E. P. (2009). A video-based observation method to assess musculoskeletal load in kitchen work. International Journal of Occupational Safety and Ergonomics, 15(1), 75-88.

Pinto, A., Nunes, I. L., \& Ribeiro, R. A. (2011). Occupational risk assessment in construction industryOverview and reflection. Safety science, 49(5), 616-624.

Piscione, J., \& Gamet, D. (2006). Effect of mechanical compression due to load carrying on shoulder muscle fatigue during sustained isometric arm abduction: an electromyographic study. European journal of applied physiology, 97(5), 573-581.

Polat, O., Özkaya, K., \& Kalınkara, V. (2016, October). Physical workload assessment of workers in furniture industry using the OWAS method. In 2nd International Furniture Congress, Proceedings, Muğla (pp. 48-54).

Posada-Quintero, H. F., Kong, Y., \& Chon, K. H. (2021). Objective Pain Stimulation Intensity and Pain Sensation Assessment Using Machine Learning Classification and Regression Based on Electrodermal Activity. American Journal of Physiology-Regulatory, Integrative and Comparative Physiology.

Ranjan, A., \& Zhao, Y. (2020, January). Prevalence of Musculoskeletal Disorders and its Impact on Lost Production Days among Industrial Workers: A Data Analytics Approach. In 2020 International Conference on COMmunication Systems \& NETworkS (COMSNETS) (pp. 35-40). IEEE.

Rasmussen, J., Damsgaard, M., Surma, E., Christensen, S. T., de Zee, M., \& Vondrak, V. (2003, May). Anybody-a software system for ergonomic optimization. In Fifth world congress on structural and multidisciplinary optimization (Vol. 4, p. 6).

Ratner, B. (2009). The correlation coefficient: Its values range between $+1 /-1$, or do they?. Journal of targeting, measurement and analysis for marketing, 17(2), 139-142.

Rosenbaum, P. R. (2005). Observational study. Encyclopedia of statistics in behavioral science.

Roquelaure, Y. (2018). Musculoskeletal disorders and psychosocial factors at work. ETUI Research PaperReport, 142. 
Segning, C. M., Ezzaidi, H., da Silva, R. A., \& Ngomo, S. (2021). A Neurophysiological Pattern as a Precursor of Work-Related Musculoskeletal Disorders Using EEG Combined with EMG. International Journal of Environmental Research and Public Health, 18(4), 2001.

Seth, A., Matias, R., Veloso, A. P., \& Delp, S. L. (2016). A biomechanical model of the scapulothoracic joint to accurately capture scapular kinematics during shoulder movements. PloS one, 11(1), e0141028.

Sigholm, G., Herberts, P., Almström, C., \& Kadefors, R. (1983). Electromyographic analysis of shoulder muscle load. Journal of Orthopaedic Research, 1(4), 379-386.

Smythe, A., Rathi, S., Pavlova, N., Littlewood, C., Connell, D., Haines, T., \& Malliaras, P. (2021). Selfreported management among people with rotator cuff related shoulder pain: An observational study. Musculoskeletal Science and Practice, 51, 102305

Sporrong, H., Palmerud, G., \& Herberts, P. (1996). Hand grip increases shoulder muscle activity: An EMG analysis with static handcontractions in 9 subjects. Acta Orthopaedica Scandinavica, 67(5), 485-490.

Sudarshan, K. C., Sharma, S., Ginn, K., Almadi, T., Subedi, H., \& Reed, D. (2019). Cross-cultural adaptation and measurement properties of the Nepali version of the DASH (disability of arm, shoulder and hand) in patients with shoulder pain. Health and quality of life outcomes, 17(1), 1-10.

Suissa, S., \& Garbe, E. (2007). Primer: administrative health databases in observational studies of drug effects - advantages and disadvantages. Nature clinical practice Rheumatology, 3(12), 725-732.

Straker, L. M., Pollock, C. M., \& Mangharam, J. E. (1997). The effect of shoulder posture on performance, discomfort and muscle fatigue whilst working on a visual display unit. International Journal of Industrial Ergonomics, 20(1), 1-10

Syuaib, M. F. (2015). Ergonomic study on the manual harvesting tasks of oil-palm plantation in Indonesia based on anthropometric, postures and work motions analyses. Agricultural Engineering International: CIGR Journal, 17(3).

Tan, H. Z., Srinivasan, M. A., Eberman, B., \& Cheng, B. (1994). Human factors for the design of forcereflecting haptic interfaces. Dynamic systems and control, 55(1), 353-359.

Thomas, D., Hare, B., \& Evangelinos, K. (2021). A comparison of manual handling risks in different domestic waste collection systems using three separate evaluation methods. International Journal of Industrial Ergonomics, 83, 103111.

Tondu, B. (2005, December). Modelling of the shoulder complex and application the design of upper extremities for humanoid robots. In 5th IEEE-RAS International Conference on Humanoid Robots, 2005. (pp. 313-320). IEEE.

Tran, T. Q., Boring, R. L., Dudenhoeffer, D. D., Hallbert, B. P., Keller, M. D., \& Anderson, T. M. (2007, August). Advantages and disadvantages of physiological assessment for next generation control room design. In 2007 IEEE 8th Human Factors and Power Plants and HPRCT 13th Annual Meeting (pp. 259263). IEEE.

Wang, K., Arima, T., Arendt-Nielsen, L., \& Svensson, P. (2000). EMG-force relationships are influenced by experimental jaw-muscle pain. Journal of Oral Rehabilitation, 27(5), 394-402. 
Yang, J., Abdel-Malek, K., \& Nebel, K. (2003). The Reach Envelope of a 9 Degree-of-Freedom Model of the Upper Extremity. IOWA UNIV IOWA CITY CENTER FOR COMPUTER AIDED DESIGN.

Yang, A., Stingl, M., Berry, D. A., Lohscheller, J., Voigt, D., Eysholdt, U., \& Döllinger, M. (2011).

Computation of physiological human vocal fold parameters by mathematical optimization of a biomechanical model. The Journal of the Acoustical Society of America, 130(2), 948-964.

Yang, J., Feng, X., Kim, J. H., \& Rajulu, S. (2010). Review of biomechanical models for human shoulder complex. International Journal of Human Factors Modelling and Simulation, 1(3), 271-2931 


\section{Appendix I: Shoulder Strain Index}

Table A1: Shoulder Strain Index

\begin{tabular}{|c|c|c|c|c|c|c|c|c|c|c|c|c|c|c|c|c|}
\hline $\begin{array}{c}\text { Should } \\
\text { er } \\
\text { angle }\end{array}$ & $\begin{array}{l}\text { Shoul } \\
\text { der } \\
\text { plane }\end{array}$ & $\begin{array}{c}\text { loa } \\
\text { d }\end{array}$ & $\begin{array}{l}\text { Dir } \\
\text { ect } \\
\text { ion }\end{array}$ & $\begin{array}{c}\mathrm{Su} \\
\text { bje } \\
\mathrm{ct} \\
1\end{array}$ & $\begin{array}{c}\mathrm{Su} \\
\text { bje } \\
\text { ct } \\
2\end{array}$ & $\begin{array}{c}\mathrm{Su} \\
\text { bje } \\
\mathrm{ct} \\
3\end{array}$ & $\begin{array}{c}\mathrm{Su} \\
\text { bje } \\
\text { ct } \\
4\end{array}$ & $\begin{array}{c}\mathrm{Su} \\
\text { bje } \\
\text { ct } \\
5\end{array}$ & $\begin{array}{c}\mathrm{Su} \\
\text { bje } \\
\text { ct } \\
6\end{array}$ & $\begin{array}{c}\mathrm{Su} \\
\text { bje } \\
\mathrm{ct} \\
7\end{array}$ & $\begin{array}{c}\mathrm{Su} \\
\text { bje } \\
\text { ct } \\
8\end{array}$ & $\begin{array}{c}\mathrm{Su} \\
\text { bje } \\
\mathrm{ct} \\
9\end{array}$ & $\begin{array}{c}\mathrm{Su} \\
\text { bje } \\
\mathrm{ct} \\
10\end{array}$ & $\begin{array}{c}\mathrm{Su} \\
\text { bje } \\
\mathrm{ct} \\
11\end{array}$ & $\begin{array}{c}\mathrm{Su} \\
\text { bje } \\
\mathrm{ct} \\
12\end{array}$ & Average \\
\hline 60 & $\begin{array}{c}\text { Sagitt } \\
\text { al }\end{array}$ & 2.5 & PB & $\begin{array}{l}13 . \\
99 \\
27 \\
12 \\
52 \\
\end{array}$ & $\begin{array}{l}14 . \\
11 \\
60 \\
87 \\
28 \\
\end{array}$ & $\begin{array}{l}16 . \\
81 \\
08 \\
65 \\
23 \\
\end{array}$ & $\begin{array}{l}14 . \\
47 \\
81 \\
40 \\
09 \\
\end{array}$ & $\begin{array}{l}14 . \\
82 \\
85 \\
72 \\
24 \\
\end{array}$ & $\begin{array}{l}14 . \\
35 \\
87 \\
80 \\
16 \\
\end{array}$ & $\begin{array}{l}17 . \\
71 \\
42 \\
33 \\
95 \\
\end{array}$ & $\begin{array}{l}14 . \\
94 \\
28 \\
87 \\
33 \\
\end{array}$ & $\begin{array}{l}12 . \\
10 \\
89 \\
25 \\
16 \\
\end{array}$ & $\begin{array}{l}15 . \\
27 \\
86 \\
66 \\
78 \\
\end{array}$ & $\begin{array}{l}12 . \\
53 \\
89 \\
76 \\
37 \\
\end{array}$ & $\begin{array}{l}13 . \\
87 \\
93 \\
99 \\
38 \\
\end{array}$ & $\begin{array}{c}14.58735 \\
387 \\
\end{array}$ \\
\hline 60 & $\begin{array}{c}\text { Sagitt } \\
\text { al }\end{array}$ & 2.5 & PD & $\begin{array}{l}0.7 \\
65 \\
23 \\
96 \\
12\end{array}$ & $\begin{array}{l}0.9 \\
37 \\
09 \\
02 \\
97\end{array}$ & $\begin{array}{l}4.4 \\
75 \\
71 \\
66 \\
75\end{array}$ & $\begin{array}{l}1.4 \\
21 \\
16 \\
22 \\
26\end{array}$ & $\begin{array}{l}1.8 \\
77 \\
56 \\
91 \\
83\end{array}$ & $\begin{array}{l}1.2 \\
77 \\
06 \\
18 \\
43\end{array}$ & $\begin{array}{c}5.6 \\
63 \\
93 \\
96 \\
3\end{array}$ & $\begin{array}{l}2.0 \\
25 \\
50 \\
21 \\
99\end{array}$ & $\begin{array}{l}2.2 \\
98 \\
84 \\
11 \\
99\end{array}$ & $\begin{array}{l}2.4 \\
75 \\
44 \\
48 \\
87\end{array}$ & $\begin{array}{l}1.7 \\
89 \\
35 \\
74 \\
31\end{array}$ & $\begin{array}{l}0.8 \\
45 \\
00 \\
74 \\
53\end{array}$ & $\begin{array}{c}2.154327 \\
72\end{array}$ \\
\hline 60 & $\begin{array}{c}\text { Sagitt } \\
\text { al }\end{array}$ & 2.5 & PL & $\begin{array}{l}17 . \\
58 \\
79 \\
43 \\
94 \\
\end{array}$ & $\begin{array}{l}17 . \\
64 \\
07 \\
07 \\
51 \\
\end{array}$ & $\begin{array}{l}19 . \\
22 \\
88 \\
56 \\
89 \\
\end{array}$ & $\begin{array}{l}17 . \\
82 \\
75 \\
60 \\
15 \\
\end{array}$ & $\begin{array}{l}18 . \\
01 \\
58 \\
02 \\
44 \\
\end{array}$ & $\begin{array}{l}17 . \\
76 \\
22 \\
53 \\
53 \\
\end{array}$ & $\begin{array}{c}19 . \\
95 \\
42 \\
13 \\
5 \\
\end{array}$ & $\begin{array}{l}18 . \\
07 \\
57 \\
18 \\
57 \\
\end{array}$ & $\begin{array}{l}16 . \\
27 \\
05 \\
94 \\
37 \\
\end{array}$ & $\begin{array}{l}18 . \\
24 \\
91 \\
48 \\
79 \\
\end{array}$ & $\begin{array}{c}16 . \\
66 \\
01 \\
90 \\
22 \\
\end{array}$ & $\begin{array}{l}17 . \\
61 \\
37 \\
49 \\
13 \\
\end{array}$ & $\begin{array}{c}17.90722 \\
825 \\
\end{array}$ \\
\hline 60 & $\begin{array}{c}\text { Sagitt } \\
\text { al }\end{array}$ & 2.5 & PR & $\begin{array}{l}12 . \\
74 \\
01 \\
52 \\
65\end{array}$ & $\begin{array}{l}12 . \\
85 \\
43 \\
23 \\
86\end{array}$ & $\begin{array}{l}15 . \\
34 \\
80 \\
19 \\
78\end{array}$ & $\begin{array}{l}13 . \\
18 \\
81 \\
79 \\
68\end{array}$ & $\begin{array}{l}13 . \\
50 \\
97 \\
27 \\
48\end{array}$ & $\begin{array}{l}13 . \\
07 \\
83 \\
03 \\
17\end{array}$ & $\begin{array}{c}16 . \\
17 \\
71 \\
70 \\
5\end{array}$ & $\begin{array}{l}3 . \\
61 \\
42 \\
98 \\
98\end{array}$ & $\begin{array}{l}10 . \\
96 \\
54 \\
28 \\
93\end{array}$ & $\begin{array}{l}13 . \\
92 \\
05 \\
44 \\
93\end{array}$ & $\begin{array}{l}11 . \\
37 \\
70 \\
46 \\
73\end{array}$ & $\begin{array}{l}12 . \\
63 \\
36 \\
24 \\
63\end{array}$ & $\begin{array}{c}13.28390 \\
178\end{array}$ \\
\hline 60 & $\begin{array}{l}\text { Sagitt } \\
\text { al }\end{array}$ & 2.5 & PU & $\begin{array}{l}26 . \\
52 \\
56 \\
33 \\
05\end{array}$ & $\begin{array}{l}26 . \\
58 \\
06 \\
38 \\
27\end{array}$ & $\begin{array}{l}27 . \\
77 \\
63 \\
74 \\
15\end{array}$ & $\begin{array}{l}26 . \\
74 \\
18 \\
85 \\
26\end{array}$ & $\begin{array}{l}26 . \\
89 \\
77 \\
65 \\
97\end{array}$ & $\begin{array}{l}26 . \\
68 \\
87 \\
49 \\
36\end{array}$ & $\begin{array}{l}28 \\
17 \\
64 \\
33 \\
28\end{array}$ & $\begin{array}{l}26 . \\
94 \\
85 \\
75 \\
61\end{array}$ & $\begin{array}{l}25 . \\
71 \\
72 \\
80 \\
23\end{array}$ & $\begin{array}{l}27 . \\
09 \\
77 \\
12 \\
04\end{array}$ & $\begin{array}{l}25 . \\
89 \\
94 \\
11 \\
59\end{array}$ & $\begin{array}{l}26 . \\
61 \\
67 \\
68 \\
42\end{array}$ & $\begin{array}{c}26.80560 \\
227\end{array}$ \\
\hline 60 & $\begin{array}{l}\text { Sagitt } \\
\text { al }\end{array}$ & 5 & PB & $\begin{array}{l}15 . \\
02 \\
83 \\
53 \\
34\end{array}$ & $\begin{array}{l}15 . \\
14 \\
69 \\
27 \\
03\end{array}$ & $\begin{array}{c}17 . \\
73 \\
19 \\
67 \\
6\end{array}$ & $\begin{array}{l}15 . \\
49 \\
47 \\
45 \\
31\end{array}$ & $\begin{array}{l}15 . \\
83 \\
12 \\
33 \\
71\end{array}$ & $\begin{array}{l}15 . \\
38 \\
00 \\
95 \\
92\end{array}$ & $\begin{array}{l}18 . \\
59 \\
69 \\
34 \\
34\end{array}$ & $\begin{array}{l}15 . \\
94 \\
09 \\
63 \\
83\end{array}$ & $\begin{array}{l}13 . \\
21 \\
47 \\
53 \\
49\end{array}$ & $\begin{array}{l}16 . \\
26 \\
31 \\
86 \\
46\end{array}$ & $\begin{array}{l}3 . \\
62 \\
93 \\
71 \\
61\end{array}$ & $\begin{array}{l}14 . \\
90 \\
84 \\
42 \\
51\end{array}$ & $\begin{array}{c}15.59724 \\
793\end{array}$ \\
\hline 60 & $\begin{array}{l}\text { Sagitt } \\
\text { al }\end{array}$ & 5 & PD & $\begin{array}{l}9.2 \\
05 \\
98 \\
67 \\
24\end{array}$ & $\begin{array}{l}9.0 \\
08 \\
92 \\
72 \\
99\end{array}$ & $\begin{array}{l}4.8 \\
05 \\
84 \\
28 \\
56\end{array}$ & $\begin{array}{l}8.4 \\
28 \\
95 \\
59 \\
39\end{array}$ & $\begin{array}{l}7.8 \\
62 \\
45 \\
13 \\
37\end{array}$ & $\begin{array}{c}8.6 \\
23 \\
08 \\
63 \\
5\end{array}$ & $\begin{array}{l}3.5 \\
44 \\
78 \\
94 \\
52\end{array}$ & $\begin{array}{l}7.6 \\
83 \\
84 \\
16 \\
34\end{array}$ & $\begin{array}{l}12 . \\
23 \\
01 \\
41 \\
25\end{array}$ & $\begin{array}{l}7.1 \\
49 \\
40 \\
06 \\
72\end{array}$ & $\begin{array}{l}11 . \\
54 \\
81 \\
49 \\
87\end{array}$ & $\begin{array}{l}9.4 \\
05 \\
55 \\
15 \\
54\end{array}$ & $\begin{array}{c}8.291427 \\
079\end{array}$ \\
\hline 60 & $\begin{array}{c}\text { Sagitt } \\
\text { al }\end{array}$ & 5 & PL & $\begin{array}{l}22 . \\
39 \\
38 \\
94 \\
74\end{array}$ & $\begin{array}{l}22 . \\
48 \\
52 \\
92 \\
48\end{array}$ & $\begin{array}{l}24 . \\
39 \\
31 \\
02 \\
03\end{array}$ & $\begin{array}{l}22 . \\
74 \\
66 \\
64 \\
06\end{array}$ & $\begin{array}{l}22 . \\
99 \\
50 \\
64 \\
02\end{array}$ & $\begin{array}{l}22 . \\
66 \\
12 \\
33 \\
42\end{array}$ & $\begin{array}{l}25 . \\
01 \\
85 \\
31 \\
41\end{array}$ & $\begin{array}{l}23 . \\
07 \\
55 \\
42 \\
47\end{array}$ & $\begin{array}{l}21 . \\
20 \\
29 \\
58 \\
86\end{array}$ & $\begin{array}{l}23 . \\
31 \\
06 \\
85 \\
86\end{array}$ & $\begin{array}{l}21 . \\
47 \\
11 \\
44 \\
07\end{array}$ & $\begin{array}{l}22 . \\
29 \\
92 \\
47 \\
31\end{array}$ & $\begin{array}{c}22.83778 \\
006\end{array}$ \\
\hline 60 & $\begin{array}{c}\text { Sagitt } \\
\text { al }\end{array}$ & 5 & PR & $\begin{array}{l}13 . \\
64 \\
56\end{array}$ & $\begin{array}{l}13 . \\
73 \\
97 \\
\end{array}$ & $\begin{array}{l}15 . \\
98 \\
53\end{array}$ & $\begin{array}{l}14 . \\
01 \\
42\end{array}$ & $\begin{array}{l}14 . \\
27 \\
75\end{array}$ & $\begin{array}{l}13 . \\
92 \\
39\end{array}$ & $\begin{array}{l}16 . \\
85 \\
27 \\
\end{array}$ & $\begin{array}{l}14 . \\
36 \\
16\end{array}$ & $\begin{array}{l}12 . \\
19 \\
69 \\
\end{array}$ & $\begin{array}{l}14 . \\
60 \\
74\end{array}$ & $\begin{array}{l}12 . \\
53 \\
14\end{array}$ & $\begin{array}{l}13 . \\
55 \\
03\end{array}$ & $\begin{array}{c}14.14058 \\
657\end{array}$ \\
\hline
\end{tabular}




\begin{tabular}{|c|c|c|c|c|c|c|c|c|c|c|c|c|c|c|c|c|}
\hline & & & & $\begin{array}{l}60 \\
47\end{array}$ & $\begin{array}{l}17 \\
69\end{array}$ & $\begin{array}{l}43 \\
55\end{array}$ & $\begin{array}{l}71 \\
78\end{array}$ & $\begin{array}{l}47 \\
34\end{array}$ & $\begin{array}{l}98 \\
47\end{array}$ & $\begin{array}{l}21 \\
72\end{array}$ & $\begin{array}{l}49 \\
89\end{array}$ & $\begin{array}{l}73 \\
11\end{array}$ & $\begin{array}{l}13 \\
77\end{array}$ & $\begin{array}{l}23 \\
86\end{array}$ & $\begin{array}{l}17 \\
22\end{array}$ & \\
\hline 60 & $\begin{array}{c}\text { Sagitt } \\
\text { al }\end{array}$ & 5 & PU & $\begin{array}{l}40 . \\
22 \\
74 \\
23 \\
96\end{array}$ & $\begin{array}{l}40 . \\
20 \\
48 \\
78 \\
09\end{array}$ & $\begin{array}{c}39 . \\
70 \\
79 \\
89 \\
55\end{array}$ & $\begin{array}{l}40 . \\
13 \\
86 \\
05 \\
39\end{array}$ & $\begin{array}{l}40 . \\
07 \\
44 \\
18 \\
19\end{array}$ & $\begin{array}{c}40 . \\
16 \\
04 \\
62 \\
6\end{array}$ & $\begin{array}{c}39 . \\
53 \\
85 \\
92 \\
13\end{array}$ & $\begin{array}{l}40 . \\
05 \\
34 \\
52 \\
68\end{array}$ & $\begin{array}{c}40 . \\
57 \\
10 \\
07 \\
12\end{array}$ & $\begin{array}{l}39 . \\
99 \\
18 \\
68 \\
08\end{array}$ & $\begin{array}{l}40 . \\
49 \\
27 \\
17 \\
93\end{array}$ & $\begin{array}{l}40 . \\
25 \\
02 \\
37 \\
53\end{array}$ & $\begin{array}{c}40.11763 \\
777\end{array}$ \\
\hline 60 & $\begin{array}{l}\text { Scap } \\
\text { ular }\end{array}$ & 2.5 & PB & $\begin{array}{l}8.1 \\
93 \\
35 \\
79 \\
49\end{array}$ & $\begin{array}{l}8.3 \\
16 \\
95 \\
84 \\
31\end{array}$ & $\begin{array}{c}11 . \\
13 \\
10 \\
18 \\
6\end{array}$ & $\begin{array}{l}8.6 \\
74 \\
99 \\
83 \\
79\end{array}$ & $\begin{array}{c}9.0 \\
15 \\
41 \\
35 \\
45\end{array}$ & $\begin{array}{l}8.5 \\
57 \\
81 \\
07 \\
42\end{array}$ & $\begin{array}{l}12 . \\
24 \\
13 \\
51 \\
49\end{array}$ & $\begin{array}{l}9.1 \\
25 \\
71 \\
38 \\
63\end{array}$ & $\begin{array}{l}6.4 \\
51 \\
92 \\
26 \\
85\end{array}$ & $\begin{array}{c}9.4 \\
67 \\
16 \\
27 \\
9\end{array}$ & $\begin{array}{l}6.7 \\
97 \\
28 \\
11 \\
99\end{array}$ & $\begin{array}{c}8.0 \\
67 \\
60 \\
53 \\
3\end{array}$ & $\begin{array}{c}8.836716 \\
251\end{array}$ \\
\hline 60 & $\begin{array}{l}\text { Scap } \\
\text { ular }\end{array}$ & 2.5 & PD & $\begin{array}{l}1.0 \\
75 \\
22 \\
40 \\
96\end{array}$ & $\begin{array}{l}1.1 \\
11 \\
01 \\
57 \\
82\end{array}$ & $\begin{array}{l}5.0 \\
40 \\
56 \\
82 \\
19\end{array}$ & $\begin{array}{l}1.6 \\
25 \\
09 \\
11 \\
94\end{array}$ & $\begin{array}{l}2.1 \\
30 \\
98 \\
03 \\
16\end{array}$ & $\begin{array}{l}1.4 \\
53 \\
65 \\
49 \\
82\end{array}$ & $\begin{array}{l}6.3 \\
91 \\
10 \\
69 \\
72\end{array}$ & $\begin{array}{l}2.2 \\
96 \\
74 \\
79 \\
46\end{array}$ & $\begin{array}{l}1.7 \\
00 \\
22 \\
43 \\
22\end{array}$ & $\begin{array}{l}2.7 \\
89 \\
68 \\
56 \\
65\end{array}$ & $\begin{array}{l}1.5 \\
85 \\
34 \\
79 \\
94\end{array}$ & $\begin{array}{l}1.1 \\
38 \\
91 \\
49 \\
97\end{array}$ & $\begin{array}{c}2.361546 \\
874\end{array}$ \\
\hline 60 & $\begin{array}{l}\text { Scap } \\
\text { ular }\end{array}$ & 2.5 & PL & $\begin{array}{l}13 . \\
87 \\
97 \\
16 \\
42\end{array}$ & $\begin{array}{c}13 . \\
99 \\
39 \\
33 \\
3\end{array}$ & $\begin{array}{c}16 . \\
55 \\
68 \\
11 \\
8\end{array}$ & $\begin{array}{l}14 . \\
32 \\
23 \\
28 \\
22\end{array}$ & $\begin{array}{c}14 . \\
64 \\
83 \\
27 \\
3\end{array}$ & $\begin{array}{l}14 . \\
21 \\
54 \\
81 \\
29\end{array}$ & $\begin{array}{l}17 . \\
30 \\
37 \\
02 \\
72\end{array}$ & $\begin{array}{l}14 . \\
77 \\
09 \\
80 \\
13\end{array}$ & $\begin{array}{l}12 . \\
01 \\
48 \\
66 \\
45\end{array}$ & $\begin{array}{l}15 . \\
12 \\
07 \\
65 \\
32\end{array}$ & $\begin{array}{l}12 . \\
44 \\
91 \\
86 \\
51\end{array}$ & $\begin{array}{l}13 . \\
76 \\
34 \\
65 \\
57\end{array}$ & $\begin{array}{c}14.41996 \\
375\end{array}$ \\
\hline 60 & $\begin{array}{l}\text { Scap } \\
\text { ular }\end{array}$ & 2.5 & PR & $\begin{array}{l}13 . \\
63 \\
64 \\
14 \\
77\end{array}$ & $\begin{array}{l}13 . \\
73 \\
44 \\
00 \\
14\end{array}$ & $\begin{array}{l}15 . \\
95 \\
91 \\
26 \\
59\end{array}$ & $\begin{array}{l}14 . \\
01 \\
95 \\
92 \\
52\end{array}$ & $\begin{array}{l}14 . \\
29 \\
23 \\
90 \\
32\end{array}$ & $\begin{array}{c}13 . \\
92 \\
59 \\
51 \\
2\end{array}$ & $\begin{array}{l}16 . \\
85 \\
47 \\
85 \\
91\end{array}$ & $\begin{array}{l}14 . \\
38 \\
07 \\
08 \\
95\end{array}$ & $\begin{array}{l}12 . \\
09 \\
04 \\
06 \\
39\end{array}$ & $\begin{array}{l}14 . \\
63 \\
81 \\
99 \\
28\end{array}$ & $\begin{array}{l}12 . \\
45 \\
06 \\
12 \\
95\end{array}$ & $\begin{array}{l}13 . \\
53 \\
69 \\
28 \\
98\end{array}$ & $\begin{array}{c}14.12662 \\
65\end{array}$ \\
\hline 60 & $\begin{array}{l}\text { Scap } \\
\text { ular }\end{array}$ & 2.5 & PU & $\begin{array}{c}25 . \\
78 \\
16 \\
29 \\
8\end{array}$ & $\begin{array}{l}25 . \\
83 \\
72 \\
70 \\
73\end{array}$ & $\begin{array}{l}27 . \\
04 \\
86 \\
59 \\
54\end{array}$ & $\begin{array}{l}26 . \\
00 \\
05 \\
27 \\
91\end{array}$ & $\begin{array}{l}26 . \\
15 \\
82 \\
10 \\
38\end{array}$ & $\begin{array}{l}25 . \\
94 \\
67 \\
12 \\
24\end{array}$ & $\begin{array}{l}27 . \\
45 \\
47 \\
08 \\
04\end{array}$ & $\begin{array}{l}26 . \\
20 \\
95 \\
12 \\
85\end{array}$ & $\begin{array}{l}24 . \\
93 \\
21 \\
04 \\
06\end{array}$ & $\begin{array}{l}26 . \\
36 \\
01 \\
82 \\
39\end{array}$ & $\begin{array}{c}25 . \\
12 \\
60 \\
21 \\
34\end{array}$ & $\begin{array}{l}25 . \\
72 \\
53 \\
69 \\
41\end{array}$ & $\begin{array}{c}26.04840 \\
906\end{array}$ \\
\hline 60 & $\begin{array}{l}\text { Scap } \\
\text { ular }\end{array}$ & 5 & PB & $\begin{array}{l}9.1 \\
37 \\
13 \\
03 \\
53\end{array}$ & $\begin{array}{l}9.0 \\
88 \\
69 \\
71 \\
34\end{array}$ & $\begin{array}{l}9.4 \\
47 \\
92 \\
66 \\
51\end{array}$ & $\begin{array}{l}8.9 \\
02 \\
93 \\
77 \\
78\end{array}$ & $\begin{array}{l}8.6 \\
38 \\
22 \\
53 \\
92\end{array}$ & $\begin{array}{l}8.9 \\
72 \\
12 \\
58 \\
64\end{array}$ & $\begin{array}{c}9.8 \\
92 \\
42 \\
96 \\
3\end{array}$ & $\begin{array}{l}8.5 \\
22 \\
87 \\
71 \\
75\end{array}$ & $\begin{array}{c}9.2 \\
73 \\
25 \\
60 \\
1\end{array}$ & $\begin{array}{l}8.6 \\
57 \\
91 \\
84 \\
26\end{array}$ & $\begin{array}{l}9.3 \\
27 \\
42 \\
14 \\
26\end{array}$ & $\begin{array}{l}9.1 \\
80 \\
69 \\
41 \\
29\end{array}$ & $\begin{array}{c}9.086803 \\
331\end{array}$ \\
\hline 60 & $\begin{array}{l}\text { Scap } \\
\text { ular }\end{array}$ & 5 & PD & $\begin{array}{l}5.0 \\
88 \\
21 \\
10 \\
02\end{array}$ & $\begin{array}{l}5.0 \\
07 \\
47 \\
83 \\
28\end{array}$ & $\begin{array}{l}3.2 \\
84 \\
90 \\
88 \\
31\end{array}$ & $\begin{array}{l}4.7 \\
80 \\
60 \\
33 \\
69\end{array}$ & $\begin{array}{l}4.5 \\
67 \\
23 \\
95 \\
63\end{array}$ & $\begin{array}{l}4.8 \\
53 \\
19 \\
38 \\
39\end{array}$ & $\begin{array}{l}2.6 \\
27 \\
43 \\
10 \\
74\end{array}$ & $\begin{array}{l}4.4 \\
97 \\
50 \\
80 \\
72\end{array}$ & $\begin{array}{l}6.2 \\
32 \\
29 \\
51 \\
46\end{array}$ & $\begin{array}{l}4.2 \\
92 \\
28 \\
74 \\
89\end{array}$ & $\begin{array}{l}5.9 \\
74 \\
87 \\
76 \\
93\end{array}$ & $\begin{array}{l}5.1 \\
52 \\
35 \\
81 \\
25\end{array}$ & $\begin{array}{c}4.696532 \\
711\end{array}$ \\
\hline 60 & $\begin{array}{l}\text { Scap } \\
\text { ular }\end{array}$ & 5 & PL & $\begin{array}{l}15 . \\
14 \\
00 \\
69 \\
04\end{array}$ & $\begin{array}{l}15 . \\
24 \\
79 \\
29 \\
07\end{array}$ & $\begin{array}{l}17 . \\
61 \\
37 \\
69 \\
47\end{array}$ & $\begin{array}{l}15 . \\
56 \\
24 \\
73 \\
05\end{array}$ & $\begin{array}{l}15 . \\
86 \\
76 \\
64 \\
44\end{array}$ & $\begin{array}{l}15 . \\
45 \\
72 \\
84 \\
27\end{array}$ & $\begin{array}{l}18 . \\
51 \\
22 \\
95 \\
42\end{array}$ & $\begin{array}{l}15 . \\
96 \\
57 \\
19 \\
14\end{array}$ & $\begin{array}{l}13 . \\
64 \\
54 \\
23 \\
76\end{array}$ & $\begin{array}{c}16 . \\
24 \\
37 \\
89 \\
8\end{array}$ & $\begin{array}{l}13 . \\
98 \\
04 \\
81 \\
97\end{array}$ & $\begin{array}{l}15 . \\
03 \\
04 \\
09 \\
54\end{array}$ & $\begin{array}{c}15.68894 \\
241\end{array}$ \\
\hline 60 & $\begin{array}{l}\text { Scap } \\
\text { ular }\end{array}$ & 5 & PR & $\begin{array}{l}17 . \\
38 \\
60 \\
39 \\
75\end{array}$ & $\begin{array}{l}17 . \\
37 \\
45 \\
08 \\
27\end{array}$ & $\begin{array}{l}18 . \\
20 \\
95 \\
06 \\
87\end{array}$ & $\begin{array}{l}17 . \\
32 \\
80 \\
72 \\
11\end{array}$ & $\begin{array}{l}17 . \\
29 \\
42 \\
97 \\
33\end{array}$ & $\begin{array}{l}17 . \\
34 \\
55 \\
76 \\
16\end{array}$ & $\begin{array}{l}18 . \\
60 \\
37 \\
93 \\
08\end{array}$ & $\begin{array}{l}17 . \\
33 \\
39 \\
14 \\
24\end{array}$ & $\begin{array}{l}17 . \\
11 \\
74 \\
93 \\
57\end{array}$ & $\begin{array}{l}17 . \\
43 \\
19 \\
91 \\
32\end{array}$ & $\begin{array}{l}17 . \\
20 \\
98 \\
32 \\
74\end{array}$ & $\begin{array}{l}17 . \\
39 \\
56 \\
74 \\
33\end{array}$ & $\begin{array}{c}17.50255 \\
831\end{array}$ \\
\hline 60 & $\begin{array}{l}\text { Scap } \\
\text { ular }\end{array}$ & 5 & PU & $\begin{array}{l}38 . \\
83 \\
02\end{array}$ & $\begin{array}{l}38 . \\
81 \\
43\end{array}$ & $\begin{array}{l}38 . \\
46 \\
50\end{array}$ & $\begin{array}{l}38 . \\
76 \\
75\end{array}$ & $\begin{array}{l}38 . \\
72 \\
21\end{array}$ & $\begin{array}{l}38 . \\
78 \\
29\end{array}$ & $\begin{array}{l}38 . \\
34 \\
74\end{array}$ & $\begin{array}{l}38 . \\
70 \\
73\end{array}$ & $\begin{array}{l}39 . \\
07 \\
31\end{array}$ & $\begin{array}{l}38 . \\
66 \\
38\end{array}$ & $\begin{array}{c}39 . \\
01 \\
78\end{array}$ & $\begin{array}{c}38 . \\
84 \\
63\end{array}$ & $\begin{array}{c}38.75320 \\
428\end{array}$ \\
\hline
\end{tabular}




\begin{tabular}{|c|c|c|c|c|c|c|c|c|c|c|c|c|c|c|c|c|}
\hline & & & & $\begin{array}{l}76 \\
13\end{array}$ & $\begin{array}{l}41 \\
58\end{array}$ & $\begin{array}{l}41 \\
04\end{array}$ & $\begin{array}{l}18 \\
66\end{array}$ & $\begin{array}{c}79 \\
1\end{array}$ & $\begin{array}{l}59 \\
82\end{array}$ & $\begin{array}{c}93 \\
8\end{array}$ & $\begin{array}{l}72 \\
57\end{array}$ & $\begin{array}{l}70 \\
58\end{array}$ & $\begin{array}{l}85 \\
18\end{array}$ & $\begin{array}{l}13 \\
77\end{array}$ & $\begin{array}{c}99 \\
1\end{array}$ & \\
\hline 120 & $\begin{array}{c}\text { Sagitt } \\
\text { al }\end{array}$ & 2.5 & PB & $\begin{array}{l}15 . \\
79 \\
22 \\
39 \\
53\end{array}$ & $\begin{array}{l}15 . \\
94 \\
77 \\
85 \\
88\end{array}$ & $\begin{array}{l}19 . \\
19 \\
94 \\
66 \\
03\end{array}$ & $\begin{array}{c}16 . \\
37 \\
92 \\
50 \\
9\end{array}$ & $\begin{array}{l}16 . \\
80 \\
28 \\
09 \\
28\end{array}$ & $\begin{array}{l}16 . \\
23 \\
49 \\
01 \\
25\end{array}$ & $\begin{array}{l}20 . \\
29 \\
13 \\
69 \\
84\end{array}$ & $\begin{array}{l}16 . \\
94 \\
10 \\
33 \\
43\end{array}$ & $\begin{array}{l}13 . \\
51 \\
56 \\
66 \\
17\end{array}$ & $\begin{array}{l}17 . \\
34 \\
69 \\
79 \\
64\end{array}$ & $\begin{array}{l}14 . \\
03 \\
51 \\
91 \\
34\end{array}$ & $\begin{array}{l}15 . \\
64 \\
14 \\
06 \\
57\end{array}$ & $\begin{array}{c}16.51067 \\
499\end{array}$ \\
\hline 120 & $\begin{array}{l}\text { Sagitt } \\
\text { al }\end{array}$ & 2.5 & PD & $\begin{array}{c}2.4 \\
36 \\
20 \\
32 \\
6\end{array}$ & $\begin{array}{l}2.5 \\
08 \\
86 \\
34 \\
29\end{array}$ & $\begin{array}{l}5.9 \\
73 \\
23 \\
01 \\
93\end{array}$ & $\begin{array}{l}3.0 \\
84 \\
40 \\
64 \\
78\end{array}$ & $\begin{array}{l}3.5 \\
44 \\
24 \\
96 \\
86\end{array}$ & $\begin{array}{l}2.9 \\
26 \\
63 \\
34 \\
65\end{array}$ & $\begin{array}{l}7.5 \\
12 \\
63 \\
29 \\
66\end{array}$ & $\begin{array}{l}3.7 \\
07 \\
64 \\
88 \\
87\end{array}$ & $\begin{array}{l}2.0 \\
94 \\
37 \\
24 \\
08\end{array}$ & $\begin{array}{l}4.1 \\
44 \\
37 \\
46 \\
48\end{array}$ & $\begin{array}{l}1.7 \\
67 \\
15 \\
50 \\
96\end{array}$ & $\begin{array}{l}2.2 \\
50 \\
66 \\
55 \\
69\end{array}$ & $\begin{array}{c}3.495869 \\
674\end{array}$ \\
\hline 120 & $\begin{array}{c}\text { Sagitt } \\
\text { al }\end{array}$ & 2.5 & PL & $\begin{array}{c}16 . \\
59 \\
05 \\
56 \\
67\end{array}$ & $\begin{array}{l}16 . \\
72 \\
79 \\
41 \\
81\end{array}$ & $\begin{array}{l}18 . \\
18 \\
24 \\
62 \\
37\end{array}$ & $\begin{array}{l}16 . \\
87 \\
31 \\
26 \\
14\end{array}$ & $\begin{array}{l}17 . \\
07 \\
97 \\
57 \\
48\end{array}$ & $\begin{array}{l}16 . \\
80 \\
43 \\
87 \\
64\end{array}$ & $\begin{array}{l}18 . \\
88 \\
11 \\
31 \\
92\end{array}$ & $\begin{array}{l}17 . \\
14 \\
66 \\
82 \\
69\end{array}$ & $\begin{array}{l}15 . \\
45 \\
02 \\
00 \\
84\end{array}$ & $\begin{array}{l}17 . \\
34 \\
23 \\
59 \\
94\end{array}$ & $\begin{array}{l}15 . \\
71 \\
34 \\
71 \\
33\end{array}$ & $\begin{array}{l}16 . \\
51 \\
69 \\
90 \\
57\end{array}$ & $\begin{array}{c}16.94242 \\
245\end{array}$ \\
\hline 120 & $\begin{array}{c}\text { Sagitt } \\
\text { al }\end{array}$ & 2.5 & PR & $\begin{array}{l}20 . \\
39 \\
62 \\
04 \\
52\end{array}$ & $\begin{array}{c}20 . \\
57 \\
49 \\
82 \\
3\end{array}$ & $\begin{array}{l}22 . \\
95 \\
43 \\
51 \\
05\end{array}$ & $\begin{array}{l}20 . \\
85 \\
27 \\
07 \\
33\end{array}$ & $\begin{array}{l}21 . \\
17 \\
19 \\
36 \\
28\end{array}$ & $\begin{array}{l}20 . \\
74 \\
19 \\
35 \\
18\end{array}$ & $\begin{array}{l}23 . \\
82 \\
90 \\
73 \\
78\end{array}$ & $\begin{array}{l}21 . \\
27 \\
30 \\
95 \\
09\end{array}$ & $\begin{array}{c}18 . \\
46 \\
03 \\
60 \\
4\end{array}$ & $\begin{array}{l}21 . \\
57 \\
40 \\
25 \\
89\end{array}$ & $\begin{array}{l}18 . \\
92 \\
19 \\
15 \\
44\end{array}$ & $\begin{array}{l}20 . \\
27 \\
36 \\
90 \\
26\end{array}$ & $\begin{array}{c}20.91868 \\
979\end{array}$ \\
\hline 120 & $\begin{array}{c}\text { Sagitt } \\
\text { al }\end{array}$ & 2.5 & PU & $\begin{array}{l}29 . \\
91 \\
54 \\
96 \\
49\end{array}$ & $\begin{array}{l}30 . \\
14 \\
45 \\
57 \\
16\end{array}$ & $\begin{array}{c}31 . \\
54 \\
19 \\
90 \\
71\end{array}$ & $\begin{array}{l}30 . \\
19 \\
54 \\
94 \\
43\end{array}$ & $\begin{array}{l}30 . \\
39 \\
76 \\
30 \\
46\end{array}$ & $\begin{array}{l}30 . \\
12 \\
66 \\
37 \\
18\end{array}$ & $\begin{array}{l}32 . \\
06 \\
37 \\
05 \\
55\end{array}$ & $\begin{array}{l}30 . \\
46 \\
36 \\
42 \\
99\end{array}$ & $\begin{array}{l}28 . \\
82 \\
97 \\
10 \\
95\end{array}$ & $\begin{array}{c}30 . \\
65 \\
74 \\
17 \\
1\end{array}$ & $\begin{array}{l}29 . \\
07 \\
74 \\
41 \\
51\end{array}$ & $\begin{array}{l}29 . \\
84 \\
35 \\
50 \\
29\end{array}$ & $\begin{array}{c}30.27143 \\
957\end{array}$ \\
\hline 120 & $\begin{array}{c}\text { Sagitt } \\
\text { al }\end{array}$ & 5 & PB & $\begin{array}{l}16 . \\
38 \\
54 \\
76 \\
62\end{array}$ & $\begin{array}{l}16 . \\
53 \\
17 \\
12 \\
84\end{array}$ & $\begin{array}{l}19 . \\
72 \\
19 \\
75 \\
73\end{array}$ & $\begin{array}{l}16 . \\
96 \\
04 \\
26 \\
28\end{array}$ & $\begin{array}{l}17 . \\
37 \\
52 \\
90 \\
61\end{array}$ & $\begin{array}{l}16 . \\
81 \\
91 \\
23 \\
82\end{array}$ & $\begin{array}{l}20 . \\
79 \\
12 \\
78 \\
26\end{array}$ & $\begin{array}{l}17 . \\
51 \\
06 \\
25 \\
16\end{array}$ & $\begin{array}{c}14 . \\
15 \\
40 \\
04 \\
2\end{array}$ & $\begin{array}{l}17 . \\
90 \\
81 \\
37 \\
41\end{array}$ & $\begin{array}{l}14 . \\
66 \\
32 \\
71 \\
72\end{array}$ & $\begin{array}{l}16 . \\
23 \\
76 \\
27 \\
87\end{array}$ & $\begin{array}{c}17.08824 \\
588\end{array}$ \\
\hline 120 & $\begin{array}{c}\text { Sagitt } \\
\text { al }\end{array}$ & 5 & PD & $\begin{array}{l}7.4 \\
98 \\
14 \\
50 \\
46\end{array}$ & $\begin{array}{l}7.3 \\
59 \\
77 \\
50 \\
04\end{array}$ & $\begin{array}{l}4.1 \\
66 \\
93 \\
13 \\
27\end{array}$ & $\begin{array}{l}6.9 \\
35 \\
34 \\
79 \\
14\end{array}$ & $\begin{array}{l}6.4 \\
95 \\
87 \\
66 \\
93\end{array}$ & $\begin{array}{l}7.0 \\
79 \\
69 \\
47 \\
91\end{array}$ & $\begin{array}{c}3.1 \\
26 \\
10 \\
65 \\
9\end{array}$ & $\begin{array}{l}6.3 \\
58 \\
14 \\
12 \\
51\end{array}$ & $\begin{array}{l}9.7 \\
53 \\
83 \\
80 \\
08\end{array}$ & $\begin{array}{l}5.9 \\
77 \\
73 \\
75 \\
14\end{array}$ & $\begin{array}{l}9.3 \\
18 \\
73 \\
84 \\
67\end{array}$ & $\begin{array}{l}7.6 \\
58 \\
33 \\
13 \\
88\end{array}$ & $\begin{array}{c}6.810721 \\
999\end{array}$ \\
\hline 120 & $\begin{array}{c}\text { Sagitt } \\
\text { al }\end{array}$ & 5 & PL & $\begin{array}{l}22 . \\
28 \\
91 \\
99 \\
25\end{array}$ & $\begin{array}{l}22 . \\
34 \\
20 \\
52 \\
89\end{array}$ & $\begin{array}{l}23 . \\
42 \\
06 \\
98 \\
46\end{array}$ & $\begin{array}{l}22 . \\
49 \\
43 \\
49 \\
64\end{array}$ & $\begin{array}{l}22 . \\
63 \\
88 \\
76 \\
54\end{array}$ & $\begin{array}{l}22 . \\
44 \\
45 \\
14 \\
31\end{array}$ & $\begin{array}{l}23 . \\
76 \\
86 \\
98 \\
51\end{array}$ & $\begin{array}{l}22 . \\
68 \\
54 \\
81 \\
82\end{array}$ & $\begin{array}{l}21 . \\
80 \\
50 \\
68 \\
96\end{array}$ & $\begin{array}{l}22 . \\
82 \\
08 \\
04 \\
34\end{array}$ & $\begin{array}{l}21 . \\
89 \\
44 \\
72 \\
99\end{array}$ & $\begin{array}{l}22 . \\
23 \\
52 \\
19 \\
01\end{array}$ & $\begin{array}{c}22.56995 \\
306\end{array}$ \\
\hline 120 & $\begin{array}{c}\text { Sagitt } \\
\text { al }\end{array}$ & 5 & PR & $\begin{array}{l}27 . \\
50 \\
96 \\
75 \\
31\end{array}$ & $\begin{array}{c}27 . \\
64 \\
55 \\
00 \\
2\end{array}$ & $\begin{array}{c}30 . \\
60 \\
67 \\
54 \\
9\end{array}$ & $\begin{array}{l}28 . \\
03 \\
67 \\
15 \\
88\end{array}$ & $\begin{array}{l}28 . \\
40 \\
71 \\
16 \\
05\end{array}$ & $\begin{array}{c}27 . \\
90 \\
88 \\
34 \\
9\end{array}$ & $\begin{array}{l}31 . \\
40 \\
01 \\
44 \\
57\end{array}$ & $\begin{array}{l}28 . \\
52 \\
65 \\
39 \\
73\end{array}$ & $\begin{array}{l}26 . \\
65 \\
64 \\
74 \\
81\end{array}$ & $\begin{array}{l}28 . \\
87 \\
40 \\
12 \\
08\end{array}$ & $\begin{array}{l}26 . \\
74 \\
52 \\
04 \\
55\end{array}$ & $\begin{array}{l}27 . \\
37 \\
09 \\
54 \\
25\end{array}$ & $\begin{array}{c}28.30732 \\
727\end{array}$ \\
\hline 120 & $\begin{array}{c}\text { Sagitt } \\
\text { al }\end{array}$ & 5 & PU & $\begin{array}{l}44 . \\
62 \\
85 \\
51 \\
43\end{array}$ & $\begin{array}{l}44 . \\
61 \\
89 \\
02 \\
41\end{array}$ & $\begin{array}{l}44 . \\
40 \\
70 \\
93 \\
88\end{array}$ & $\begin{array}{l}44 . \\
59 \\
05 \\
46 \\
22\end{array}$ & $\begin{array}{l}44 . \\
56 \\
31 \\
27 \\
96\end{array}$ & $\begin{array}{l}44 . \\
59 \\
98 \\
95 \\
17\end{array}$ & $\begin{array}{l}44 . \\
33 \\
55 \\
10 \\
29\end{array}$ & $\begin{array}{l}44 . \\
55 \\
41 \\
70 \\
33\end{array}$ & $\begin{array}{l}44 . \\
77 \\
58 \\
87 \\
24\end{array}$ & $\begin{array}{l}44 . \\
52 \\
78 \\
85 \\
08\end{array}$ & $\begin{array}{c}44 . \\
74 \\
22 \\
66 \\
5\end{array}$ & $\begin{array}{l}44 . \\
63 \\
83 \\
19 \\
25\end{array}$ & $\begin{array}{c}44.58184 \\
631\end{array}$ \\
\hline 120 & $\begin{array}{l}\text { Scap } \\
\text { ular }\end{array}$ & 2.5 & PB & $\begin{array}{l}14 . \\
18 \\
20\end{array}$ & $\begin{array}{l}14 . \\
20 \\
73\end{array}$ & $\begin{array}{l}14 . \\
70 \\
82\end{array}$ & $\begin{array}{l}14 . \\
28 \\
20\end{array}$ & $\begin{array}{l}14 . \\
35 \\
33\end{array}$ & $\begin{array}{l}14 . \\
25 \\
74\end{array}$ & $\begin{array}{l}14 . \\
83 \\
80\end{array}$ & $\begin{array}{l}14 . \\
37 \\
63\end{array}$ & $\begin{array}{l}13 . \\
73 \\
41\end{array}$ & $\begin{array}{l}14 . \\
44 \\
22\end{array}$ & $\begin{array}{l}13 . \\
84 \\
67\end{array}$ & $\begin{array}{l}14 . \\
15 \\
70\end{array}$ & $\begin{array}{c}14.28209 \\
628\end{array}$ \\
\hline
\end{tabular}




\begin{tabular}{|c|c|c|c|c|c|c|c|c|c|c|c|c|c|c|c|c|}
\hline & & & & $\begin{array}{l}86 \\
89\end{array}$ & $\begin{array}{l}90 \\
09\end{array}$ & $\begin{array}{l}45 \\
34\end{array}$ & $\begin{array}{l}36 \\
41\end{array}$ & $\begin{array}{l}81 \\
28\end{array}$ & $\begin{array}{l}71 \\
68\end{array}$ & $\begin{array}{l}09 \\
74\end{array}$ & $\begin{array}{l}17 \\
79\end{array}$ & $\begin{array}{l}30 \\
37\end{array}$ & $\begin{array}{l}96 \\
41\end{array}$ & $\begin{array}{l}65 \\
05\end{array}$ & $\begin{array}{l}24 \\
37\end{array}$ & \\
\hline 120 & $\begin{array}{l}\text { Scap } \\
\text { ular }\end{array}$ & 2.5 & PD & $\begin{array}{l}1.8 \\
22 \\
15 \\
22 \\
93\end{array}$ & $\begin{array}{l}1.8 \\
24 \\
26 \\
75 \\
89\end{array}$ & $\begin{array}{l}2.9 \\
29 \\
36 \\
16 \\
59\end{array}$ & $\begin{array}{l}1.8 \\
45 \\
47 \\
28 \\
81\end{array}$ & $\begin{array}{l}1.8 \\
67 \\
08 \\
89 \\
99\end{array}$ & $\begin{array}{l}1.8 \\
41 \\
75 \\
48 \\
26\end{array}$ & $\begin{array}{l}3.8 \\
11 \\
81 \\
00 \\
78\end{array}$ & $\begin{array}{l}1.8 \\
75 \\
81 \\
74 \\
59\end{array}$ & $\begin{array}{l}1.5 \\
58 \\
83 \\
93\end{array}$ & $\begin{array}{l}1.9 \\
06 \\
10 \\
89 \\
67\end{array}$ & $\begin{array}{c}1.6 \\
61 \\
19 \\
89 \\
2\end{array}$ & $\begin{array}{l}1.8 \\
35 \\
13 \\
89 \\
33\end{array}$ & $\begin{array}{c}2.064917 \\
659\end{array}$ \\
\hline 120 & $\begin{array}{l}\text { Scap } \\
\text { ular }\end{array}$ & 2.5 & PL & $\begin{array}{l}11 . \\
01 \\
67 \\
29 \\
43\end{array}$ & $\begin{array}{l}11 . \\
04 \\
73 \\
20 \\
72\end{array}$ & $\begin{array}{c}11 . \\
53 \\
06 \\
98 \\
5\end{array}$ & $\begin{array}{l}11 . \\
13 \\
47 \\
26 \\
28\end{array}$ & $\begin{array}{l}11 . \\
21 \\
58 \\
29 \\
61\end{array}$ & $\begin{array}{l}11 . \\
10 \\
63 \\
05 \\
47\end{array}$ & $\begin{array}{l}11 . \\
73 \\
34 \\
26 \\
99\end{array}$ & $\begin{array}{l}11 . \\
24 \\
15 \\
44 \\
17\end{array}$ & $\begin{array}{l}10 . \\
50 \\
75 \\
04 \\
88\end{array}$ & $\begin{array}{l}11 . \\
31 \\
52 \\
21 \\
29\end{array}$ & $\begin{array}{l}10 . \\
62 \\
95 \\
72 \\
64\end{array}$ & $\begin{array}{c}10 . \\
98 \\
54 \\
13 \\
6\end{array}$ & $\begin{array}{c}11.12202 \\
446\end{array}$ \\
\hline 120 & $\begin{array}{l}\text { Scap } \\
\text { ular }\end{array}$ & 2.5 & PR & $\begin{array}{l}10 . \\
47 \\
18 \\
50 \\
01\end{array}$ & $\begin{array}{c}10 . \\
56 \\
10 \\
33 \\
5\end{array}$ & $\begin{array}{l}12 . \\
10 \\
52 \\
75 \\
99\end{array}$ & $\begin{array}{l}10 . \\
80 \\
97 \\
27 \\
77\end{array}$ & $\begin{array}{l}11 . \\
03 \\
20 \\
43 \\
87\end{array}$ & $\begin{array}{l}10 . \\
73 \\
02 \\
57 \\
44\end{array}$ & $\begin{array}{l}12 . \\
49 \\
39 \\
12 \\
69\end{array}$ & $\begin{array}{l}11 . \\
10 \\
16 \\
97 \\
19\end{array}$ & $\begin{array}{l}9.6 \\
64 \\
13 \\
20 \\
97\end{array}$ & $\begin{array}{l}11 . \\
29 \\
78 \\
04 \\
28\end{array}$ & $\begin{array}{l}9.7 \\
23 \\
87 \\
10 \\
17\end{array}$ & $\begin{array}{l}10 . \\
38 \\
54 \\
26 \\
19\end{array}$ & $\begin{array}{c}10.86475 \\
267\end{array}$ \\
\hline 120 & $\begin{array}{l}\text { Scap } \\
\text { ular }\end{array}$ & 2.5 & PU & $\begin{array}{l}16 . \\
02 \\
01 \\
90 \\
38\end{array}$ & $\begin{array}{l}16 . \\
05 \\
36 \\
06 \\
91\end{array}$ & $\begin{array}{c}16 . \\
78 \\
46 \\
60 \\
5\end{array}$ & $\begin{array}{l}16 . \\
15 \\
16 \\
90 \\
49\end{array}$ & $\begin{array}{l}16 . \\
24 \\
66 \\
74 \\
61\end{array}$ & $\begin{array}{l}16 . \\
11 \\
93 \\
49 \\
39\end{array}$ & $\begin{array}{l}17 . \\
03 \\
02 \\
17 \\
93\end{array}$ & $\begin{array}{l}16 . \\
27 \\
76 \\
61 \\
39\end{array}$ & $\begin{array}{l}15 . \\
51 \\
06 \\
26 \\
18\end{array}$ & $\begin{array}{l}16 . \\
36 \\
87 \\
22 \\
75\end{array}$ & $\begin{array}{l}15 . \\
62 \\
68 \\
42 \\
89\end{array}$ & $\begin{array}{l}15 . \\
98 \\
64 \\
08 \\
05\end{array}$ & $\begin{array}{c}16.18138 \\
762\end{array}$ \\
\hline 120 & $\begin{array}{l}\text { Scap } \\
\text { ular }\end{array}$ & 5 & $\mathrm{~PB}$ & $\begin{array}{l}20 . \\
94 \\
35 \\
59 \\
51\end{array}$ & $\begin{array}{l}20 . \\
95 \\
66 \\
67 \\
44\end{array}$ & $\begin{array}{c}21 . \\
15 \\
22 \\
58 \\
3\end{array}$ & $\begin{array}{l}20 . \\
99 \\
08 \\
62 \\
65\end{array}$ & $\begin{array}{c}21 . \\
04 \\
04 \\
46 \\
2\end{array}$ & $\begin{array}{l}20 . \\
97 \\
99 \\
76 \\
31\end{array}$ & $\begin{array}{c}21 . \\
10 \\
55 \\
07 \\
38\end{array}$ & $\begin{array}{l}21 . \\
05 \\
47 \\
36 \\
94\end{array}$ & $\begin{array}{l}20 . \\
61 \\
83 \\
98 \\
49\end{array}$ & $\begin{array}{l}21 . \\
09 \\
33 \\
00 \\
52\end{array}$ & $\begin{array}{l}20 . \\
71 \\
62 \\
95 \\
11\end{array}$ & $\begin{array}{l}20 . \\
92 \\
94 \\
55 \\
75\end{array}$ & $\begin{array}{c}20.96512 \\
205\end{array}$ \\
\hline 120 & $\begin{array}{l}\text { Scap } \\
\text { ular }\end{array}$ & 5 & PD & $\begin{array}{c}5.3 \\
65 \\
95 \\
92 \\
9\end{array}$ & $\begin{array}{l}5.1 \\
99 \\
81 \\
02 \\
59\end{array}$ & $\begin{array}{l}2.5 \\
91 \\
28 \\
79 \\
73\end{array}$ & $\begin{array}{l}4.7 \\
09 \\
69 \\
09 \\
75\end{array}$ & $\begin{array}{l}4.2 \\
35 \\
09 \\
28 \\
37\end{array}$ & $\begin{array}{l}4.8 \\
71 \\
76 \\
11 \\
55\end{array}$ & $\begin{array}{l}2.3 \\
63 \\
21 \\
54 \\
24\end{array}$ & $\begin{array}{l}4.0 \\
95 \\
21 \\
86 \\
11\end{array}$ & $\begin{array}{l}8.0 \\
35 \\
12 \\
47 \\
69\end{array}$ & $\begin{array}{l}3.6 \\
81 \\
28 \\
54 \\
63\end{array}$ & $\begin{array}{l}7.4 \\
23 \\
53 \\
01 \\
61\end{array}$ & $\begin{array}{l}5.5 \\
33 \\
62 \\
26 \\
49\end{array}$ & $\begin{array}{c}4.842133 \\
297\end{array}$ \\
\hline 120 & $\begin{array}{l}\text { Scap } \\
\text { ular }\end{array}$ & 5 & PL & $\begin{array}{l}15 . \\
78 \\
35 \\
19 \\
75\end{array}$ & $\begin{array}{l}15 . \\
79 \\
78 \\
89 \\
84\end{array}$ & $\begin{array}{l}16 . \\
07 \\
29 \\
25 \\
02\end{array}$ & $\begin{array}{l}15 . \\
83 \\
94 \\
13 \\
68\end{array}$ & $\begin{array}{c}15 . \\
87 \\
84 \\
24 \\
3\end{array}$ & $\begin{array}{c}15 . \\
82 \\
58 \\
51 \\
5\end{array}$ & $\begin{array}{l}16 . \\
14 \\
41 \\
38 \\
48\end{array}$ & $\begin{array}{l}15 . \\
89 \\
08 \\
76 \\
36\end{array}$ & $\begin{array}{l}15 . \\
52 \\
41 \\
40 \\
59\end{array}$ & $\begin{array}{l}15 . \\
92 \\
66 \\
92 \\
56\end{array}$ & $\begin{array}{c}15 . \\
59 \\
21 \\
61 \\
62\end{array}$ & $\begin{array}{l}15 . \\
76 \\
87 \\
24 \\
01\end{array}$ & $\begin{array}{c}15.83706 \\
314\end{array}$ \\
\hline 120 & $\begin{array}{l}\text { Scap } \\
\text { ular }\end{array}$ & 5 & PR & $\begin{array}{l}15 . \\
42 \\
74 \\
32 \\
76\end{array}$ & $\begin{array}{l}15 . \\
39 \\
00 \\
37 \\
71\end{array}$ & $\begin{array}{l}14 . \\
90 \\
47 \\
72 \\
29\end{array}$ & $\begin{array}{l}15 . \\
27 \\
14 \\
81 \\
37\end{array}$ & $\begin{array}{l}15 . \\
14 \\
50 \\
04 \\
25\end{array}$ & $\begin{array}{l}15 . \\
31 \\
19 \\
84 \\
44\end{array}$ & $\begin{array}{l}14 . \\
83 \\
65 \\
59 \\
95\end{array}$ & $\begin{array}{l}15 . \\
10 \\
08 \\
94 \\
11\end{array}$ & $\begin{array}{c}16 . \\
72 \\
36 \\
87 \\
5\end{array}$ & $\begin{array}{l}14 . \\
96 \\
38 \\
57 \\
06\end{array}$ & $\begin{array}{l}16 . \\
35 \\
16 \\
02 \\
08\end{array}$ & $\begin{array}{l}15 . \\
46 \\
36 \\
46 \\
01\end{array}$ & $\begin{array}{c}15.40757 \\
996\end{array}$ \\
\hline 120 & $\begin{array}{l}\text { Scap } \\
\text { ular }\end{array}$ & 5 & PU & $\begin{array}{l}24 . \\
19 \\
27 \\
24 \\
18\end{array}$ & $\begin{array}{l}24 . \\
18 \\
10 \\
70 \\
89\end{array}$ & $\begin{array}{l}23 . \\
92 \\
66 \\
43 \\
61\end{array}$ & $\begin{array}{l}24 . \\
14 \\
68 \\
49 \\
29\end{array}$ & $\begin{array}{l}24 . \\
11 \\
37 \\
42 \\
74\end{array}$ & $\begin{array}{l}24 . \\
15 \\
81 \\
30 \\
99\end{array}$ & $\begin{array}{l}23 . \\
84 \\
15 \\
35 \\
32\end{array}$ & $\begin{array}{c}24 . \\
10 \\
29 \\
45 \\
4\end{array}$ & $\begin{array}{l}24 . \\
37 \\
07 \\
48 \\
16\end{array}$ & $\begin{array}{l}24 . \\
07 \\
12 \\
32 \\
97\end{array}$ & $\begin{array}{l}24 . \\
33 \\
01 \\
18 \\
51\end{array}$ & $\begin{array}{l}24 . \\
20 \\
45 \\
20 \\
65\end{array}$ & $\begin{array}{c}24.13668 \\
856\end{array}$ \\
\hline
\end{tabular}




\section{Appendix II: RMS Values of Shoulder Muscles}

Table A2: RMS values of seven shoulder muscles

\begin{tabular}{|c|c|c|c|c|c|c|c|c|c|c|c|}
\hline Angle & Plane & $\begin{array}{c}\text { Weig } \\
\text { ht } \\
\text { (lbs) }\end{array}$ & $\begin{array}{l}\text { Dire } \\
\text { ction }\end{array}$ & $\begin{array}{l}\text { Supras } \\
\text { pinatus }\end{array}$ & $\begin{array}{l}\text { Infra } \\
\text { spina } \\
\text { tus }\end{array}$ & $\begin{array}{c}\text { Midd } \\
\text { le } \\
\text { deltoi } \\
\text { d }\end{array}$ & $\begin{array}{c}\text { Ante } \\
\text { rior } \\
\text { deltoi } \\
\text { d }\end{array}$ & $\begin{array}{c}\text { Poste } \\
\text { rior } \\
\text { deltoi } \\
\text { d }\end{array}$ & $\begin{array}{c}\text { Bicep } \\
\mathbf{s}\end{array}$ & $\begin{array}{c}\text { Trice } \\
\text { ps }\end{array}$ & $\begin{array}{l}\text { Average } \\
\text { Muscle } \\
\text { activity }\end{array}$ \\
\hline 60 & 90 & 2.5 & PB & 0.0846 & $\begin{array}{c}0.084 \\
88\end{array}$ & $\begin{array}{c}0.053 \\
14\end{array}$ & $\begin{array}{c}0.118 \\
44\end{array}$ & $\begin{array}{c}0.022 \\
646\end{array}$ & $\begin{array}{c}0.025 \\
54\end{array}$ & $\begin{array}{c}0.093 \\
65\end{array}$ & 0.068985143 \\
\hline 60 & 90 & 2.5 & PD & 0.03426 & $\begin{array}{c}0.064 \\
79\end{array}$ & $\begin{array}{c}0.031 \\
38\end{array}$ & $\begin{array}{c}0.078 \\
68\end{array}$ & $\begin{array}{c}0.020 \\
324\end{array}$ & $\begin{array}{c}0.019 \\
343\end{array}$ & $\begin{array}{c}0.138 \\
73\end{array}$ & 0.055358143 \\
\hline 60 & 90 & 2.5 & PL & 0.03074 & $\begin{array}{c}0.110 \\
02\end{array}$ & $\begin{array}{c}0.072 \\
11 \\
\end{array}$ & $\begin{array}{c}0.188 \\
1\end{array}$ & $\begin{array}{c}0.028 \\
33\end{array}$ & $\begin{array}{c}0.187 \\
56\end{array}$ & $\begin{array}{c}0.111 \\
66\end{array}$ & 0.104074286 \\
\hline 60 & 90 & 2.5 & PR & 0.1319 & $\begin{array}{c}0.192 \\
14 \\
\end{array}$ & $\begin{array}{c}0.104 \\
84\end{array}$ & $\begin{array}{c}0.135 \\
05\end{array}$ & $\begin{array}{c}0.064 \\
07\end{array}$ & $\begin{array}{c}0.067 \\
73\end{array}$ & 0.117 & 0.116104286 \\
\hline 60 & 90 & 2.5 & $\mathrm{PU}$ & 0.14214 & $\begin{array}{c}0.227 \\
99\end{array}$ & $\begin{array}{c}0.126 \\
07\end{array}$ & $\begin{array}{c}0.219 \\
52\end{array}$ & $\begin{array}{c}0.057 \\
01\end{array}$ & $\begin{array}{c}0.160 \\
09\end{array}$ & $\begin{array}{c}0.116 \\
9\end{array}$ & 0.14996 \\
\hline 60 & 90 & 5 & PB & 0.06891 & $\begin{array}{c}0.074 \\
25\end{array}$ & $\begin{array}{c}0.028 \\
52\end{array}$ & $\begin{array}{c}0.054 \\
11\end{array}$ & $\begin{array}{c}0.020 \\
315\end{array}$ & $\begin{array}{c}0.021 \\
97\end{array}$ & $\begin{array}{c}0.143 \\
35\end{array}$ & 0.058775 \\
\hline 60 & 90 & 5 & $\mathrm{PD}$ & $\begin{array}{c}0.02145 \\
6 \\
\end{array}$ & $\begin{array}{c}0.056 \\
3 \\
\end{array}$ & $\begin{array}{c}0.016 \\
867\end{array}$ & $\begin{array}{c}0.015 \\
795 \\
\end{array}$ & $\begin{array}{c}0.028 \\
3 \\
\end{array}$ & $\begin{array}{c}0.019 \\
099 \\
\end{array}$ & $\begin{array}{c}0.254 \\
19 \\
\end{array}$ & 0.058858143 \\
\hline 60 & 90 & 5 & PL & 0.03231 & $\begin{array}{c}0.106 \\
11\end{array}$ & $\begin{array}{c}0.069 \\
42\end{array}$ & $\begin{array}{c}0.198 \\
69\end{array}$ & $\begin{array}{c}0.032 \\
56\end{array}$ & $\begin{array}{c}0.258 \\
36\end{array}$ & $\begin{array}{c}0.138 \\
09\end{array}$ & 0.119362857 \\
\hline 60 & 90 & 5 & PR & 0.18678 & $\begin{array}{c}0.310 \\
3\end{array}$ & $\begin{array}{c}0.141 \\
72\end{array}$ & $\begin{array}{c}0.110 \\
39\end{array}$ & $\begin{array}{c}0.112 \\
94\end{array}$ & $\begin{array}{c}0.104 \\
36\end{array}$ & $\begin{array}{c}0.183 \\
92\end{array}$ & 0.164344286 \\
\hline 60 & 90 & 5 & PU & 0.18546 & $\begin{array}{c}0.349 \\
14 \\
\end{array}$ & 0.169 & $\begin{array}{c}0.270 \\
39\end{array}$ & $\begin{array}{c}0.087 \\
85\end{array}$ & $\begin{array}{c}0.235 \\
8\end{array}$ & $\begin{array}{c}0.150 \\
93 \\
\end{array}$ & 0.206938571 \\
\hline 60 & 45 & 2.5 & $\mathrm{~PB}$ & 0.136 & $\begin{array}{c}0.099 \\
52\end{array}$ & $\begin{array}{c}0.065 \\
06\end{array}$ & $\begin{array}{c}0.068 \\
37 \\
\end{array}$ & $\begin{array}{c}0.035 \\
52\end{array}$ & $\begin{array}{c}0.027 \\
49 \\
\end{array}$ & $\begin{array}{c}0.105 \\
71 \\
\end{array}$ & 0.07681 \\
\hline 60 & 45 & 2.5 & PD & 0.09325 & $\begin{array}{c}0.071 \\
72\end{array}$ & $\begin{array}{c}0.035 \\
22\end{array}$ & $\begin{array}{c}0.043 \\
16\end{array}$ & $\begin{array}{c}0.023 \\
492\end{array}$ & $\begin{array}{c}0.017 \\
794\end{array}$ & $\begin{array}{c}0.160 \\
35\end{array}$ & 0.063569429 \\
\hline 60 & 45 & 2.5 & PL & 0.10158 & $\begin{array}{c}0.107 \\
57\end{array}$ & $\begin{array}{c}0.084 \\
5\end{array}$ & $\begin{array}{c}0.155 \\
48\end{array}$ & $\begin{array}{c}0.032 \\
45\end{array}$ & 0.144 & $\begin{array}{c}0.091 \\
35\end{array}$ & 0.102418571 \\
\hline 60 & 45 & 2.5 & PR & 0.20517 & $\begin{array}{c}0.211 \\
56\end{array}$ & $\begin{array}{c}0.130 \\
15\end{array}$ & $\begin{array}{c}0.072 \\
31\end{array}$ & $\begin{array}{c}0.130 \\
37\end{array}$ & $\begin{array}{c}0.058 \\
72\end{array}$ & $\begin{array}{c}0.160 \\
52\end{array}$ & 0.1384 \\
\hline 60 & 45 & 2.5 & PU & 0.23064 & $\begin{array}{c}0.185 \\
61\end{array}$ & $\begin{array}{c}0.153 \\
58\end{array}$ & $\begin{array}{c}0.181 \\
46\end{array}$ & $\begin{array}{c}0.081 \\
6\end{array}$ & $\begin{array}{c}0.156 \\
14\end{array}$ & $\begin{array}{c}0.112 \\
04\end{array}$ & 0.157295714 \\
\hline 60 & 45 & 5 & PB & 0.13136 & $\begin{array}{c}0.103 \\
19\end{array}$ & $\begin{array}{c}0.035 \\
88\end{array}$ & $\begin{array}{c}0.021 \\
13\end{array}$ & $\begin{array}{c}0.030 \\
23\end{array}$ & $\begin{array}{c}0.020 \\
405\end{array}$ & $\begin{array}{c}0.154 \\
55\end{array}$ & 0.070963571 \\
\hline 60 & 45 & 5 & PD & 0.03507 & $\begin{array}{c}0.063 \\
14\end{array}$ & $\begin{array}{c}0.019 \\
634\end{array}$ & $\begin{array}{c}0.014 \\
62\end{array}$ & $\begin{array}{c}0.024 \\
894\end{array}$ & $\begin{array}{c}0.020 \\
799\end{array}$ & $\begin{array}{c}0.265 \\
68\end{array}$ & 0.063405286 \\
\hline 60 & 45 & 5 & PL & 0.08538 & $\begin{array}{c}0.126 \\
15\end{array}$ & $\begin{array}{c}0.087 \\
02\end{array}$ & $\begin{array}{c}0.188 \\
72\end{array}$ & $\begin{array}{c}0.033 \\
5\end{array}$ & $\begin{array}{c}0.238 \\
91\end{array}$ & $\begin{array}{c}0.132 \\
07\end{array}$ & 0.127392857 \\
\hline 60 & 45 & 5 & PR & 0.28715 & $\begin{array}{c}0.362 \\
3\end{array}$ & $\begin{array}{c}0.180 \\
51\end{array}$ & $\begin{array}{c}0.087 \\
95\end{array}$ & $\begin{array}{c}0.215 \\
91\end{array}$ & $\begin{array}{c}0.090 \\
98\end{array}$ & $\begin{array}{c}0.263 \\
54\end{array}$ & 0.21262 \\
\hline 60 & 45 & 5 & PU & 0.31493 & $\begin{array}{c}0.286 \\
26\end{array}$ & $\begin{array}{c}0.227 \\
81\end{array}$ & $\begin{array}{c}0.246 \\
2\end{array}$ & $\begin{array}{c}0.139 \\
38\end{array}$ & $\begin{array}{c}0.237 \\
02\end{array}$ & $\begin{array}{c}0.158 \\
96\end{array}$ & 0.23008 \\
\hline $120^{\circ}$ & 45 & 2.5 & $\mathrm{~PB}$ & 0.20371 & $\begin{array}{c}0.190 \\
11 \\
\end{array}$ & $\begin{array}{c}0.211 \\
11 \\
\end{array}$ & $\begin{array}{c}0.267 \\
54\end{array}$ & $\begin{array}{c}0.109 \\
66\end{array}$ & $\begin{array}{c}0.105 \\
15 \\
\end{array}$ & $\begin{array}{c}0.112 \\
28 \\
\end{array}$ & 0.171365714 \\
\hline
\end{tabular}




\begin{tabular}{|c|c|c|c|c|c|c|c|c|c|c|c|}
\hline 120 & 90 & 2.5 & PD & 0.06274 & $\begin{array}{c}0.067 \\
15\end{array}$ & $\begin{array}{c}0.091 \\
43\end{array}$ & $\begin{array}{c}0.151 \\
37\end{array}$ & $\begin{array}{c}0.038 \\
32\end{array}$ & $\begin{array}{c}0.029 \\
42\end{array}$ & $\begin{array}{c}0.109 \\
73\end{array}$ & 0.078594286 \\
\hline $120^{\circ}$ & 90 & 2.5 & PL & 0.17856 & $\begin{array}{c}0.162 \\
47\end{array}$ & $\begin{array}{c}0.195 \\
23\end{array}$ & $\begin{array}{c}0.270 \\
55\end{array}$ & $\begin{array}{c}0.085 \\
57\end{array}$ & $\begin{array}{c}0.234 \\
21\end{array}$ & $\begin{array}{c}0.124 \\
05\end{array}$ & 0.178662857 \\
\hline $120^{\circ}$ & 90 & 2.5 & PR & 0.17616 & $\begin{array}{c}0.209 \\
91\end{array}$ & $\begin{array}{c}0.216 \\
08\end{array}$ & $\begin{array}{c}0.125 \\
88\end{array}$ & $\begin{array}{c}0.176 \\
95\end{array}$ & $\begin{array}{c}0.065 \\
29\end{array}$ & $\begin{array}{c}0.215 \\
18\end{array}$ & 0.16935 \\
\hline 120 & 90 & 2.5 & PU & 0.23662 & $\begin{array}{c}0.245 \\
7\end{array}$ & $\begin{array}{c}0.252 \\
08\end{array}$ & $\begin{array}{c}0.287 \\
38\end{array}$ & $\begin{array}{c}0.147 \\
39\end{array}$ & $\begin{array}{c}0.173 \\
86\end{array}$ & $\begin{array}{c}0.142 \\
02\end{array}$ & 0.21215 \\
\hline $120^{\circ}$ & 90 & 5 & PB & 0.25083 & $\begin{array}{c}0.200 \\
58 \\
\end{array}$ & $\begin{array}{c}0.246 \\
3 \\
\end{array}$ & $\begin{array}{c}0.282 \\
25 \\
\end{array}$ & $\begin{array}{c}0.143 \\
51 \\
\end{array}$ & $\begin{array}{c}0.128 \\
57 \\
\end{array}$ & $\begin{array}{c}0.138 \\
97 \\
\end{array}$ & 0.198715714 \\
\hline $120^{\circ}$ & 90 & 5 & PD & 0.03694 & $\begin{array}{c}0.061 \\
23\end{array}$ & $\begin{array}{c}0.021 \\
56\end{array}$ & $\begin{array}{c}0.040 \\
08\end{array}$ & $\begin{array}{c}0.018 \\
721\end{array}$ & 0.022 & $\begin{array}{c}0.136 \\
18\end{array}$ & 0.048101571 \\
\hline 120 & 90 & 5 & PL & 0.19095 & $\begin{array}{c}0.208 \\
7\end{array}$ & 0.201 & $\begin{array}{c}0.307 \\
96\end{array}$ & $\begin{array}{c}0.100 \\
63\end{array}$ & $\begin{array}{c}0.385 \\
5\end{array}$ & $\begin{array}{c}0.188 \\
86\end{array}$ & 0.226228571 \\
\hline $120^{\circ}$ & 90 & 5 & PR & 0.18361 & $\begin{array}{c}0.271 \\
31\end{array}$ & $\begin{array}{c}0.234 \\
75\end{array}$ & $\begin{array}{c}0.094 \\
7\end{array}$ & $\begin{array}{c}0.274 \\
27\end{array}$ & $\begin{array}{c}0.068 \\
25\end{array}$ & $\begin{array}{c}0.308 \\
4\end{array}$ & 0.205041429 \\
\hline $120^{\circ}$ & 90 & 5 & PU & 0.31586 & $\begin{array}{c}0.372 \\
29\end{array}$ & $\begin{array}{c}0.334 \\
08\end{array}$ & $\begin{array}{c}0.375 \\
93\end{array}$ & $\begin{array}{c}0.235 \\
15\end{array}$ & $\begin{array}{c}0.253 \\
19\end{array}$ & $\begin{array}{c}0.219 \\
96\end{array}$ & 0.300922857 \\
\hline $120^{\circ}$ & 90 & 2.5 & $\mathrm{~PB}$ & 0.25248 & $\begin{array}{c}0.148 \\
01\end{array}$ & $\begin{array}{c}0.235 \\
97\end{array}$ & $\begin{array}{c}0.232 \\
36\end{array}$ & $\begin{array}{c}0.140 \\
97\end{array}$ & $\begin{array}{c}0.125 \\
48\end{array}$ & $\begin{array}{c}0.129 \\
52\end{array}$ & 0.180684286 \\
\hline 120 & 45 & 2.5 & PD & 0.12207 & $\begin{array}{c}0.080 \\
13\end{array}$ & $\begin{array}{c}0.110 \\
09\end{array}$ & $\begin{array}{c}0.113 \\
75\end{array}$ & $\begin{array}{c}0.058 \\
41\end{array}$ & $\begin{array}{c}0.037 \\
64\end{array}$ & $\begin{array}{c}0.126 \\
96\end{array}$ & 0.092721429 \\
\hline $120^{\circ}$ & 45 & 2.5 & PL & 0.19235 & $\begin{array}{c}0.121 \\
17\end{array}$ & $\begin{array}{c}0.185 \\
94\end{array}$ & $\begin{array}{c}0.226 \\
48\end{array}$ & $\begin{array}{c}0.089 \\
05\end{array}$ & $\begin{array}{c}0.196 \\
34\end{array}$ & $\begin{array}{c}0.113 \\
83\end{array}$ & 0.160737143 \\
\hline $120^{\circ}$ & 45 & 2.5 & PR & 0.25544 & $\begin{array}{c}0.182 \\
14 \\
\end{array}$ & $\begin{array}{c}0.287 \\
06 \\
\end{array}$ & $\begin{array}{c}0.132 \\
78 \\
\end{array}$ & $\begin{array}{c}0.263 \\
76 \\
\end{array}$ & $\begin{array}{c}0.084 \\
85 \\
\end{array}$ & $\begin{array}{c}0.220 \\
87 \\
\end{array}$ & 0.203842857 \\
\hline 120 & 45 & 2.5 & $\mathrm{PU}$ & 0.29187 & $\begin{array}{c}0.182 \\
07 \\
\end{array}$ & $\begin{array}{c}0.311 \\
16 \\
\end{array}$ & $\begin{array}{c}0.291 \\
51 \\
\end{array}$ & $\begin{array}{c}0.212 \\
82 \\
\end{array}$ & $\begin{array}{c}0.203 \\
28 \\
\end{array}$ & $\begin{array}{c}0.164 \\
55 \\
\end{array}$ & 0.236751429 \\
\hline $120^{\circ}$ & 45 & 5 & PB & 0.27526 & $\begin{array}{c}0.162 \\
65\end{array}$ & $\begin{array}{c}0.256 \\
08\end{array}$ & $\begin{array}{c}0.223 \\
6\end{array}$ & $\begin{array}{c}0.157 \\
7\end{array}$ & $\begin{array}{c}0.140 \\
74\end{array}$ & $\begin{array}{c}0.141 \\
93\end{array}$ & 0.193994286 \\
\hline $120^{\circ}$ & 45 & 5 & PD & 0.06848 & $\begin{array}{c}0.073 \\
71 \\
\end{array}$ & $\begin{array}{c}0.034 \\
86 \\
\end{array}$ & $\begin{array}{c}0.029 \\
21 \\
\end{array}$ & $\begin{array}{c}0.027 \\
76 \\
\end{array}$ & $\begin{array}{c}0.021 \\
5 \\
\end{array}$ & $\begin{array}{c}0.168 \\
13 \\
\end{array}$ & 0.060521429 \\
\hline 120 & 45 & 5 & PL & 0.17987 & $\begin{array}{c}0.135 \\
35\end{array}$ & 0.156 & $\begin{array}{c}0.245 \\
2\end{array}$ & $\begin{array}{c}0.064 \\
97\end{array}$ & $\begin{array}{c}0.303 \\
4\end{array}$ & $\begin{array}{c}0.132 \\
97\end{array}$ & 0.173965714 \\
\hline $120^{\circ}$ & 45 & 5 & PR & 0.32512 & $\begin{array}{c}0.292 \\
92\end{array}$ & $\begin{array}{c}0.364 \\
28\end{array}$ & $\begin{array}{c}0.126 \\
9\end{array}$ & $\begin{array}{c}0.434 \\
6\end{array}$ & $\begin{array}{c}0.101 \\
52\end{array}$ & $\begin{array}{c}0.367 \\
5\end{array}$ & 0.287548571 \\
\hline $120^{\circ}$ & 45 & 5 & PU & 0.4037 & $\begin{array}{c}0.298 \\
84\end{array}$ & $\begin{array}{c}0.385 \\
9\end{array}$ & $\begin{array}{c}0.347 \\
72\end{array}$ & $\begin{array}{c}0.276 \\
6\end{array}$ & $\begin{array}{c}0.298 \\
39\end{array}$ & $\begin{array}{c}0.213 \\
28\end{array}$ & 0.317775714 \\
\hline
\end{tabular}

\footnotetext{
${ }^{\mathrm{i}} \mathrm{https} / / / \mathrm{www}$. sports-health.com/sports-injuries/shoulder-injuries/guide-shoulder-anatomy

${ }^{\text {ii }}$ https://physio-study.com/biomechanics-of-the-shoulder/

iii https://www.researchgate.net/figure/a-Position-of-the-humeral-head-with-respect-to-the-glenoid-cavity-

b-Concavity_fig3_271215335
} 